\title{
A CRÍTICA DE HEIDEGGER À METAFÍSICA - CONTRIBUIÇÃO PARA O ESTUDO DA SUBJETIVIDADE JURÍDICA
}

Tese de Doutorado apresentado para depósito final ao Departamento de Filosofia e Teoria Geral do Direito para obtenção do título de Doutor sob a orientação da Professora Doutora JEANNETTE ANTONIOS MAMAN

FACULDADE DE DIREITO - CURSO DE PÓS-GRADUAÇÃO Departamento de Filosofia e Teoria Geral do Direito 

BANCA 
EDGAR SOLANO

USP 3204416

\section{A CRÍTICA DE HEIDEGGER À METAFÍSICA - CONTRIBUIÇÃO PARA O ESTUDO DA SUBJETIVIDADE JURÍDICA}

Tese de Doutorado apresentado para depósito final ao Departamento de Filosofia e Teoria Geral do Direito para obtenção do título de Doutor sob a orientação da Professora Doutora JEANNETTE ANTONIOS MAMAN

FACULDADE DE DIREITO DA UNIVERSIDADE DE SÃO PAULO

Departamento de Filosofia e Teoria Geral do Direito

São Paulo, 20 de maio de 2014 


\section{AGRADECIMENTO}

Se alguém me ensinou existencialmente o que é ser-com-o-outro e o que é cura, esta foi a minha cara orientadora, Profa. Dra. Jeannette Antonios Maman, a quem tenho a liberdade de chamar carinhosamente de "Mestra", porque é assim que ela se manifesta para mim. A ela agradeço pela sua existência na minha vida, pelos ensinamentos, pela atenção e pela paciência com que me orienta e exige evolução nas leituras. Sua integridade de caráter no relacionamento com os outros e o seu querer o melhor para os caros são invejáveis e espero também aprender isso com ela. Sua humildade em apoiar e ajudar aqueles que realmente necessitam é modelo a ser seguido por todos que circulam pelos meios acadêmicos, além, sem dúvida alguma, da generosidade em partilhar a preciosidade do seu pensamento e escritos que, junto com o seu mestre, Prof. Aloysio Ferraz Pereira (a quem também faço homenagem de gratidão), introduziram a filosofia de Heidegger no pensamento jurídico brasileiro.

Agradeço a minha esposa Patrícia e os meus filhos, Maria Eugênia e João Lucas, pelo apoio, pela paciência e compreensão durante esses anos.

Agradeço a todos os professores com os quais tive o prazer de conviver, especialmente o Prof. Dr. Alysson Leandro Mascaro, a quem conheci nos bancos de sala de aula quando ele terminava o seu doutorado. Da amizade rendeu admiração. Continuo a conversar sempre com ele, especialmente por meio de seus livros. Obrigado pelos ensinamentos, críticas e sugestões de quem espero aprender muito com a amizade e troca de ideias. 


\section{RESUMO}

O presente trabalho está dividido em duas partes.

Na primeira se busca a origem da noção de sujeito de direito e de subjetividade jurídica, fazendo um apanhado dos autores mais clássicos que desenvolveram as noções, tentando mostrar semelhanças e diferenças, dentro de um eixo histórico.

Na segunda parte, se focaliza o pensamento de Martin Heidegger e sua crítica à metafísica no apresentar de alguns de seus termos principais, evidenciando que a criação da subjetividade jurídica gerada pela sociedade atual produziu um isolamento existencial contrário ao "ser-com-o-outro".

Tudo na pretensão de tentar demonstrar que com a visão heideggeriana é possível realizar uma crítica ontológica ao Direito

Palavras-chave: Heidegger, Sujeito de direito, Subjetividade. 


\section{RÉSUMÉ}

Le texte présent est divisé em deux parties. Dans la première on recherche l'origine de la notion de sujet de droit et de la subjectivité juridique, en faisant un résumé des auteurs les plus classiques qui ont développé les deux notions, en tentant montrer les similitudes et les différences, dans un axe historique.

Dans la deuxième partie, on focalise la pensée de Martin Heidegger et sa critique de la métaphysique, en présentant quelques-uns de ses termes principaux, démontrant que la création de la subjectivité juridique engendrée par la société actuelle a produit un isolement existentiel contraire au "être comme l'autre".

Tout dans le souhait de tenter démontrer que dans la vision heideggerienne il est possible de réaliser une critique ontologique du droit.

Mots-clé : Heidegger, Sujet de droit, Subjectivité 


\section{ÍNDICE}

$\begin{array}{ll}\text { Prefácio } & 1\end{array}$

Introdução 3

Capítulo I - Origens da expressão "sujeito de direito"

a) Como chegamos ao sujeito de direito? 5

b) A filosofia de Descartes, Kant e Hegel 22

c) O sujeito em Marx (autor e ator da história) 49

Capítulo II - Construção analítica de Heidegger 61

a) Constituição do Dasein $\quad 75$

$\begin{array}{ll}\text { b) Autêntico e inautêntico } & 78\end{array}$

$\begin{array}{lr}\text { c) Mundo e mundanidade } & 80\end{array}$

Capítulo III - A crítica à metafísica (pensamento filosófico moderno) 82

Capítulo IV - Humanismo em Heidegger

a) Liberdade $\quad 87$

b) Verdade $\quad 88$

$\begin{array}{ll}\text { c) Direito } & 90\end{array}$

Capítulo V - Crítica de Heidegger à doutrina de Platão sobre a verdade 99

$\begin{array}{lr}\text { Razões Finais } & 128\end{array}$

$\begin{array}{ll}\text { Conclusão } & 131\end{array}$

$\begin{array}{ll}\text { Bibliografia } & 134\end{array}$ 


\section{PREFÁCIO}

"O que é a fenomenologia? Pode parecer estranho que ainda se precise colocar essa questão meio século depois dos primeiros trabalhos de Husserl. Todavia, ela está longe de estar resolvida. A fenomenologia é o estudo das essências, e todos os problemas, segunda ela, resumem-se em definir essências, a essência da percepção, a essência da consciência, por exemplo. Mas a fenomenologia é também uma filosofia que repõe as essências na existência, e não pensa que se possa compreender o homem e o mundo de outra maneira senão a partir de sua 'faticidade'. É uma filosofia transcendental que coloca em suspenso, para compreendê-las, as afirmações da atitude natural, mas é também uma filosofia para a qual o mundo já está sempre 'ali', antes da reflexão, como uma presença inalienável, e cujo esforço todo consiste em reencontrar este contato ingênuo com o mundo, para dar-lhe enfim um estatuto filosófico. É uma ambição de uma filosofia que seja uma 'ciência exata', mas é também um relato do espaço, do tempo, do mundo 'vividos'. (...)

O mundo está ali antes de qualquer análise que eu possa fazer dele, e seria artificial fazê-lo derivar de uma série de sínteses que ligariam as sensações, depois os aspectos perspectivos do objeto, quando ambos são justamente produtos da análise e não devem ser realizados antes dela. A análise reflexiva acredita seguir em sentido inverso o caminho de uma instituição prévia, e atingir no 'homem interior', como diz Santo Agostinho, um poder constituinte que ele sempre foi. Assim a reflexão arrebata-se a si mesma e se recoloca em uma objetividade invulnerável, para aquém do ser e do tempo. Mas isso é uma ingenuidade ou, se se preferir, uma reflexão incompleta que perde a consciência de seu próprio começo. Eu comecei a refletir, minha reflexão é reflexão sobre um irrefletido, ela não pode ignorar-se a si mesma como acontecimento, logo ela se manifesta como uma verdadeira criação, como uma mudança de estrutura da consciência, e cabe-lhe reconhecer, para aquém de suas operações, o mundo que é dado ao sujeito, porque o sujeito é dado a si 
mesmo. O real deve ser descrito, não construído ou constituído. Isso quer dizer que não posso assimilar a percepção às sínteses que são da ordem do juízo, dos atos e da predicação. A cada momento, meu campo perceptivo é preenchido de reflexos, de estalidos, de impressões táteis fugazes que não posso ligar de maneira precisa ao contexto percebido e que, todavia, eu situo imediatamente no mundo, sem confundi-los nunca com minhas divagações. A cada instante também eu fantasio acerca de coisas, imagino objetos ou pessoas cuja presença aqui não é incompatível com o contexto, e todavia eles não se misturam ao mundo, eles estão adiante do mundo, no teatro do imaginário. Se a realidade de minha percepção só estivesse fundada na coerência intrínseca das 'representações', ela deveria ser sempre hesitante e, abandonado às minhas conjecturas prováveis, eu deveria a cada momento desfazer sínteses ilusórias e reintegrar ao real fenômenos aberrantes que primeiramente eu teria excluído dele. Não é nada disso. O real é um tecido sólido, ele não espera nossos juízos para anexar a si os fenômenos mais aberrantes, nem para rejeitar nossas imaginações mais verossímeis. A percepção não é uma ciência do mundo, não é nem mesmo um ato, uma tomada de posição deliberada; ela é o fundo sobre o qual todos os atos se destacam e ela é pressuposta por eles. O mundo não é um objeto do qual possuo comigo a lei de constituição; ele é o meio natural e o campo de todos os meus pensamentos e de todas as minhas percepções explícitas. A verdade não 'habita' apenas o 'homem interior', ou antes, não existe homem interior, o homem está no mundo, é no mundo que ele conhece. Quando volto a mim a partir do dogmatismo do senso comum ou do dogmatismo da ciência, encontro não um foco de verdade intrínseca, mas um sujeito consagrado ao mundo". ${ }^{1}$

\footnotetext{
${ }^{1}$ Maurice Merleau-Ponty, Fenomenologia da percepção, p. 1-6.
} 


\section{INTRODUÇÃO}

Este trabalho pretende contribuir com a filosofia do direito apontando um dentre os vários caminhos que podem existir para o repensar de conceitos cristalizados na teoria jurídica.

Norteado pela filosofia do ser na analítica existencial do Dasein de Martin Heidegger, se considera possível encontrar o novo caminho que se deseja para pensar e estudar o sentido do ser jurídico, tal como foi levado a diante pela fenomenologia heideggeriana.

Muito embora Martin Heidegger não tenha escrito especificamente sobre o Direito, o seu pensamento extrapola os temas sobre os quais tenha se detido de forma nominal e marca, com a vitalidade de suas ideias, tantos outros campos e posicionamentos contemporâneos, inclusive o Direito, no questionamento das estruturas existenciais do fenômeno jurídico, abandonando o conservadorismo e o racionalismo ${ }^{2}$, o que de nenhum modo levará ao irracionalismo, mas apontará novas formas de se apresentar as noções que fazem sentido quando pensamos na existência do Dasein como ser-no-mundo-com-ooutro.

Tendo por base a interpretação ontológica fundamental heideggeriana do ser-no-mundo-com-o-outro, a pesquisa experimenta as noções de sujeito de direito e de subjetividade jurídica e suas consequências para a reflexão jusfilosófica na tentativa de compreender os caracteres ontológicos pelos quais se esclarece o próprio fenômeno do direito, se considerado como sendo mais que uma simples tomada de conhecimento.

Partindo da analítica existenciária do Dasein (ser humano ex-istente), que conduz Heidegger a desenvolver noção própria de temporalidade e de ser-com-o-mundo, o trabalho trata da verdade como aletheia, que provoca o desvelar do caminho para a compreensão de quem se coloca no caminho para compreensão da realidade fenomenológica do entre o que existe (no qual se pode viver) e o que está "ao alcance da mão" (o próprio fazer) no fenômeno do Direito.

\footnotetext{
${ }^{2}$ Mundo intelegível.
} 
Como contribuição à filosofia do direito, se percorrerão trilhas já pavimentadas pelo positivismo jurídico e pela racionalidade ocidental, firmada pela metafísica entendida aqui como filosofia ocidental tradicional.

Escolheram-se posições de alguns autores, sem deixar de colocar um breve histórico que acompanha as noções de sujeito de direito e de sua subjetividade.

Essas noções, acrescida da de estado democrático de direito, são como as colunas de sustentação que suportam toda a estrutura da organização sócio-jurídica da atual sociedade. Mas, elas são inerentes à natureza humana ou não? De onde elas vêm? Como surgem? E principalmente, por que surgem? É de condição universal ou abraça somente alguns indivíduos?

A filosofia de Martin Heidegger com sua crítica à metafísica pode ajudar na compreensão do sujeito de direito e de subjetividade jurídica, pois há momento para o surgimento e outro para o esquecimento. Os reflexos do seu pensamento sobre a metafísica e sobre a realidade podem possibilitar um caminho novo, uma nova via, de acesso para esta investigação. 


\title{
Capítulo I - Origens da expressão "sujeito de direito"
}

\section{a) Como chegamos ao sujeito de direito?}

O sujeito de direito não brota espontaneamente da natureza e nem se identifica necessariamente com aquele que se toma por ser humano ou mesmo por pessoa.

\begin{abstract}
“Ninguém é 'pessoa' por natureza ou nascimento, originalmente. Bastaria já existência da escravidão para o demonstrar. Ser 'pessoa' é apenas o resultado dum acto de personificação que só a ordem jurídica pode praticar. Tanto as pessoas 'singulares' como as 'coletivas' ou 'jurídicas' são, de facto, mera criação da lei”. 3
\end{abstract}

Trata de uma instituição exigida pela e da cultura jurídica, como tantos outras que se registram ao longo da caminhada da história do direito, como elemento cultural que é. É uma construção histórica, como ensina vários autores, porque também dependeu de fenômenos e eventos que, influenciados por pressões quanto a suas relações político-sociais, dirigiram e contribuíram para a sua existência, numa tentativa de buscar respostas para indigências e momentos pontuais.

Na sua origem, etimologicamente, o termo sujeito vem do latim clássico subjectus que traduz tanto a noção de ou se colocar em posição inferior a outro, como a de ser capaz de se vincular com outro em obrigações e direitos.

Seja numa ou noutra, fica claro que o termo apressa em conter no seu significado sempre uma relação com outro que, no caso mais moderno, se focaliza entre o sujeito e o Estado (que lhe faz existir), mediada pela força de lei e fundamentando o direito ${ }^{4}$.

\footnotetext{
${ }^{3}$ Gustav Radbruch, Filosofia do direito, p. 262.

4 Sujeito do direito diz respeito à relação entre a pessoa humana e o Estado, relação esta que, na modernidade, é mediada pela força de lei. O fundamento do Direito reside na força, que tende a se negar enquanto violência porque se constitui a partir da lei fundada pelos próprios sujeitos que estarão submetidos a ela. Ser sujeito de direito, então, significa constituir-se como ator no processo de criação das leis (diretamente ou por intermédio de seus representantes) e das suas fontes de legitimação; envolve o processo de se colocar contra as formas de dominação de dominação e sob uma lei comum. Estado e
} 
O sujeito de direito é fruto do caminhar histórico do homem. Ele aparece em determinado momento como resposta de específica necessidade temporal, no caso, daquele período que causou a ruptura com a tradição medieval, dominada pelo pensamento da patrística e da escolástica, do posterior, denominado de modernidade.

A partir do século XVII, a situação sócio-econômico-cultural da Europa exigiu fundamentos novos não só para a economia, para a política, para a sociedade e para a religião, principais temas na época.

A exigência, de igual forma, também atingiu e foi reclamação para o direito, a fim que ele estabelecesse noções e princípios que fossem de característica análoga aos sócio-econômido-sultural e permitisse o desenvolvimento do pensamento liberal burguês que se iniciava.

Dentro deles, o sujeito de direito e o desenvolvimento do subjetivismo jurídico surgem como elementos de inovação jurídica.

Promovida pelo pensamento de Descartes que estabeleceu a primazia da autonomia da razão, a sociedade moderna com seu típico direito reconheceu no ser humano a capacidade de emancipação e de progresso, de ser sujeito de direito, tornando-o capaz de determinar suas próprias regras de conduta e, por consequência, de ser responsável na relação a outro

Estava delineado uma das suas colunas de sustentação do novo estado que nascia, juntamente, como já apontado, com a noção do estado democrático de direito ${ }^{5}$.

Sem menor dúvida, é de modo pleno aceitável afirmar que o sujeito do direito é uma instituição jurídica construída pela necessidade do direito moderno ${ }^{6}$.

Da origem até aproximadamente meados dos séculos XIV, o sujeito dentro do direito era visto sempre com agudo fundamento na relação social, como classicamente foi colocado por Platão (e depois também por Aristóteles e outros), o primeiro a sistematizar uma reflexão sobre o direito e a justiça, cujas raízes estão nos

indivíduo estão submetidos ao Direito. Este último é o responsável por organizar a mediação entre subjetividade individual (sujeito de direito) e a subjetividade coletiva (Estado)." - Fabiana Cristina Severino in Sujeito no direito, p.14.

${ }^{5}$ Fabiana Cristina Severino in Sujeito no direito, p.13.

${ }^{6}$ Yves C. Zarka, La outra vía de lasubjetividad, p. 18 e seguintes. 
ensinamentos e, sobretudo, na experiência vivida no julgamento e na morte de seu mestre, Sócrates.

Assim antes, diferentemente do pensamento moderno que dissocia direito e justiça ${ }^{7}$, é evidente a vinculação entre a pólis e seu cidadão, não existindo possibilidade para que aquele seja bom sem que esse assim também o seja ${ }^{8}$ (e vice-versa), o que culminará na propaganda do rei filósofo tido como um místico do conhecimento.

Também em Aristóteles ${ }^{9}$ - que junto com Sócrates e Platão representam o classicismo filosófico jurídico, o sujeito ainda não perde sua bagagem social. Muito embora alguns tentem ver na sua famosa colocação da inclinação da alma virtuosa para o bem uma nascente tendência individualista, sua ideia parte sempre da observação da polis,.

Colocando a justiça como fruto do mérito e proporcional medida entre necessariamente quatro elementos, Aristóteles oferece uma viva relação do sujeito para com os outros da sociedade com os quais se relaciona. Ou seja:

"o indivíduo está senão no interior da cidade (o homem é 'animal político')..."

Melhor exemplo está na sua explicação de justiça como reciprocidade e equidade.

Deste modo permaneceu no direito até a modernidade: o sujeito era de direito se pertencente e compartilhasse sua vida dentro de uma sociedade que dava visibilidade de vida $^{11}$ e ditava o seu desempenho de vida.

Ocorre uma sinalização de mudança com a pregação de Paulo de Tarso, sistematizador da teoria religiosa cristã.

Com a aceitação da pregação cristã-paulina, o cristão apresenta uma certa libertação da polis e deixa de possuir um vínculo de exclusividade com ela para ser muito

\footnotetext{
${ }^{7}$ Alysson L. Mascaro,Filosofia do direito, p. 42 e 56 e seguintes.

8 "A politeia reproduz (...) a composição do ser humano. A ordem no macrocosmo político decorre da harmonia de cada cidadão. (...) Portanto, não há virtude individual que se não projete no meio social, Nem condição coletiva que não se interiorize no homem." - Aloysio F. Pereira, História da filosofia do direito, p. 53.

${ }^{9}$ Metafísica, VII, 3.

${ }^{10}$ Michel Villey, Filosofia do Direito, p. 107.

${ }^{11}$ Como é ainda hoje: o estado diz quem a pessoa é pela documentação que lhe segue. Sem um passaporte no estrangeiro, por exemplo, a pessoa é ninguém.
} 
mais um cidadão do Reino de Deus. Este anúncio encrava dentro de si uma propaganda de certa liberdade política em face da polis que não fora vista antes e, assim, impõe um início da teoria do sujeito e da sua individualidade ${ }^{12}$ perante todos e perante o estado.

Repercute no jurídico terreno a catequese divulgada pelo cristianismo que aponta julgamento particular de cada crente perante Deus onde, cada um responderá individualmente no tribunal divino.

Muito embora isto aconteça (somando a noção de um Deus que, apesar de trino, ou seja, três pessoas distintas, uma comunidade, é divindade única, o que será adotada de forma mais radical pelo protestantismo), o sujeito individual típico moderno ainda não se completa, porque o crente somente será salvo se estiver na graça de Deus de ter a fé salvadora em Jesus Cristo, colocando-o ainda em relação a uma autoridade social a quem deve obedecer por vontade divina e necessariamente integrar uma comunidade eclesial que traz consigo dogmas, tradições, ritos e ensinamentos que não são frutos particulares de expressão, mas doutrinas moldadas pela comunidade a qual pertence.

Muito embora se tenha no discurso cristão uma relação intersubjetiva fiel-Deus-outro (denominado de "próximo"), não se deve esquecer que a teoria cristã surge com uma mensagem religiosa bem definida que é a de anunciar e demonstrar que Jesus Cristo é o filho de Deus, salvador e imolado para remissão dos pecados de todos.

A reflexão filosófica e jurídica cristã da qual surge é consequência e feita sob medida para alicerçar àquela específica teologia.

Da pregação de Paulo, os modelos e conceitos eternos ditos, por resultado, universais, mas ainda com influências nas raízes gregas, se mantêm como autoridade absoluta na cultura, não havendo significativa diferença entre os primeiros séculos da era cristã e aqueles outros, seja de Agostinho de Hipona, seja até o de Tomás de Aquino, donde aparece o germe da noção moderna do indivíduo como sujeito de direito.

Muito embora não se complete, é na pregação paulina que irá se iniciar o rompimento do paradigma da identidade grupal que apresentará, como consequência, a consolidação da noção de subjetividade entendido como "caráter de todos os fenômenos da

12 “Geralmente se reconhece que a filosofia chamada 'moderna', tanto quanto oposta à antiga, é um produto do cristianismo. Hegel, virtuose da História da Filosofia, ligava à aparição do Evangelho e da Igreja Cristã o advento do subjetivismo". - Michel Villey, Filosofia do direito, p. 107. 
consciência, ou seja, os que o sujeito relaciona consigo mesmo e chama de "meus",13, conceito este que será mais tarde abraçado de forma plena no desenvolvimento e na ascensão do pensamento burguês iniciado a partir do século XIV-XVII, tornando o subjetivismo $^{14}$ quase uma hegemonia absoluta até o pensamento atual, muito embora o pensamento medieval, com fulcro na divindade, não tenha abafado por completo perante este, apresentando sobrevida principalmente dentro das doutrinas e instituições religiosas hodiernas.

Entende-se, portanto, Nicola Abbagnano que apresenta duas interpretações para o termo "subjetividade":

"1. Caráter de todos os fenômenos psíquicos, enquanto fenômenos de consciência (v.), que o sujeito relaciona consigo mesmo e chama de "meus".

2. Caráter do que é subjetivo no sentido de ser aparente, ilusório ou falível. Nesse sentido. Hegel situava na esfera cia subjetividade o dever-ser em geral, bem como os interesses e as metas do indivíduo. Dizia: 'Uma vez que o conteúdo dos interesses e das metas está presente apenas na esfera unilateral do subjetivo, e que a unilateraliclacle é um limite, essa falta manifesta-se ao mesmo tempo como inquietação, como dor, como algo negativo"”.

É justamente contra Tomás de Aquino que pesa a acusação de terem sido os seus ensinamentos os causadores da entrada da laicização (ou seja, da autonomia das atividades humanas perante Deus, no entendo para crer) na filosofia medieval e da própria religião cristã (que depois será reforçada por Hobbes e outros), retirando dela mistérios dogmáticos que mantinham os adeptos atrelados aos encantos de sedução dos discursos e das cerimônias religiosas.

Desta forma, a pregação cristã abrirá caminhos para o enfraquecimento do poder religioso frente ao poder estatal dos estados modernos que, apesar ainda em formação, se fortalecerão cada vez mais, e, depois, especialmente com o auxílio das

\footnotetext{
${ }^{13}$ Nicola Abbagnano, Dicionário de filosofia, verbete.

${ }^{14}$ Nicola Abbagnano traduz o verbete subjetivismo como "termo moderno que designa a doutrina que reduz a realidade ou os valores a estados ou atos do sujeito (universal ou individual). Nesse sentido, o idealismo é $\mathrm{S}$. porque reduz a realidade das coisas a estados do sujeito (percepções ou representações); analogamente, fala-se de S. moral e S. estético quando o bem, o mal, o belo ou o feio são reduzidos às preferências individuais. Esse termo é empregado na maioria das vezes com intenções polêmicas, e por isso não comporta grande precisão de significado". - Dicionário de filosofia, verbete.
} 
ciências nascentes e os ensinos de Tomás (tidos como frutos inesperados) contribuíram para o advento do mundo e da cultura moderna.

Todavia, inda durante todo este período, o sujeito continuará dissolvido no meio social e será considerado habitante se e somente se enquanto pertencente a determinada cidade ou estado donde retira não só sua segurança e fonte de alimentação, mas até a sua própria identidade (o estrangeiro e o escravo, por exemplo, embora protegidos pela segurança da pólis, não gozavam do status jurídico de habitante, ou seja, não havia nenhuma relação entre eles e a pólis).

Deste modo se entende de como era grave da pena de "ex-comunhão" (tirar do comum, expulsar), entendida como a exclusão de um membro da filiação ou comunidade. Era a de maior gravidade para a pessoa que vivia anterior a Idade Moderna, pois, vagando pelas regiões que se encontra entre as cidades, terras de ninguém, o excomungado passava a ser considerada como que uma espécie de indesejado e de apátrida, ou seja, ninguém, sem relação com um qualquer meio social e, por resultado, sem direitos que lhe protegesse.

Mesmo séculos depois de Platão, de Aristóteles, de Paulo, de Agostinho e de Tomás, ainda não havia a necessidade por novas culturas e concepções, vez que a burguesia não emergia em suas conquistas político-sociais, situação que irá perdurar até meados do século XVII.

Mesmo o todo do movimento do Renascimento - período marcado pelas transformações em muitas das áreas da vida humana e que assim assinalam como sendo o acontecimento que registra o final da Idade Média e início da Idade Moderna, com a passagem do sistema feudal de estrutura medieval para o capitalismo iniciante, embora traga uma quebra com o sagrado e com as tradições religiosas, não se proclamava sinal tanto relevante para o surgimento do sujeito do direito, pois, não obstante de ser um movimento de caráter leigo e burguês, a cultura do século renascentista ainda se apoiava naquela da antiguidade clássica grega, como o seu próprio nome já descreve.

O Renascimento foi uma ruptura com a cultura medieval, porém, não tão radical como infortunados anunciam. E a razão de prova disto está, por exemplo, no fato de que, apesar da renascença ser tida como uma manifestação de uma capacidade do espírito humano, nela aflora que tal capacidade fora concedido por Deus. 
Se se questionava o mundo, era porque Deus tinha dado esta possibilidade, na qual o homem exercia algo que lhe fora dado pela bondade divina.

Neste sentido, Marcelo Bedocchio expõe que:

“Os documentos ingleses consistentes na Magna Carta, outorgada em 1215, pelo Rei João Sem-Terra da Inglaterra, a Petition of Rights de 1628, o Habeas Corpus Act de 1679 e a Bill of Rights de 1689, considerados antecedentes das declarações positivas de direitos, embora envolvessem limitação do poder estatal não encenavam substancialmente declarações de direitos por não se destinarem ao homem comum e sim a testamentos sociais específicos (Nobreza, Clero); estruturalmente são contratos feudais escritos voltados a obrigações concretas e não ao reconhecimento de direitos gerais."15.

Porém, é no momento em que a Renascença se apoia menos nos clássicos e mais nas seitas e nas filosofias helênicas (de modo especial, no estoicismo, no epicurismo e, mesmo séculos depois, na dita heresia cristã do maniqueísmo, os quais focam seus ensinos na vida pessoal do adepto) que, historicamente, surgem os primeiros sinais mais visíveis do nascimento da subjetividade, iniciando a interrupção com a cultura do mundo antigo e medieval, com o interesse e defesa das noções de liberdade, de igualdade e de fraternidade como elementos intrínsecos ao ser humano.

\section{Ensina Miguel Reale:}

"É assim que, no campo do Direito, surge um movimento que ocupa mais de três séculos na história do Ocidente, sob a rubrica ambígua da Escola do Direito Natural, abrangendo um número imenso de pensadores, inclusive alguns dos maiores espíritos da chamada civilização burguesa.

A Escola do Direito Natural ou do Jusnaturalismo distingue-se da concepção clássica do Direito Natural aristotélico-tomista por este motivo principal: enquanto para Santo Tomás primeiro se dá a 'lei' para depois se pôr o problema do 'agir segundo a lei', para aquela corrente põe-se primeiro o 'individuo' com o seu poder de agir, para depois se pôr a 'lei'. Para o homem do Renascimento o dado primordial é o indivíduo, como ser capaz de pensar e

\footnotetext{
${ }^{15}$ in Sujeito no direito, p. 104.
} 
agir. Em primeiro lugar, está o indivíduo, com todos os seus problemas, com todas as suas exigências. É da autoconsciência do indivíduo que vai resultar a lei." 16

As raízes do direito subjetivo podem ser encontradas neste ambiente cultural burguês desinteressado pela vida em comunidade, busca um novo "monastério" para focalizar o desenvolvendo das noções de humanismo e antropocentrismo (o homem toma o lugar de Deus e é o centro da criação) e de individualismo (ser isolado de seus semelhantes), o que acontecerá especialmente pelos ensinos de um mundo contingente e mantido externo da corrupção do caos ainda pela racionalidade divina em Guilherme de Ockham $^{17}$, considerado como a fonte nascente do pensamento moderno.

Muito embora possa se reconhecer favoráveis logo na filosofia antiga, Guilherme de Ockham introduz uma nova via de pensamento filosófico que mais tarde ficará conhecida como nominalismo (muito embora exista quem defenda que seja mais correto definir o seu pensamento como sendo o conceiptualismo realista), que, como traz Nicola Abbagnano ${ }^{18}$, constituiu uma das grandes correntes da escolástica e da filosofia ocidental e que, muito embora já se tenha convergência de defensas por primeiro em Roscelino e Abelardo no século XIII, foi com Guilherme de Ockham que realçou e encontrou seu lugar na história da filosofia.

A tese principal do nominalismo pode ser resumida na admissão de que o universal ou conceito nada mais é que um signo dotado de aptidão de ser predicado de várias coisas.

Na referida obra, Nicola Abbagnano cita Guilherme de Ockham:

"Nada fora da alma, nem por si nem por algo de real ou de racional que lhe seja acrescentado, de qualquer modo que seja considerado e entendido, é universal, pois é tão impossível que algo fora da alma seja de qualquer modo universal (a menos que isso se dê por convenção, como quando se considera universal a palavra 'homem', que é particular), quanto é impossível que o homem, segundo qualquer consideração ou qualquer ser, seja asno".

\footnotetext{
${ }^{16}$ Filosofia do Direito, p. 646.

${ }^{17}$ Ockham é a sua cidade natal, um condado de Surrey, que se localizava próximo a cidade de Londres no final do século XIII.

${ }^{18}$ Dicionário de filosofia, verbete.
} 
Por mais estranho que possa parecer (e mesmo para não dizer contraditório que seja), ser ou fazer qualquer referência ao "universal" denominado de nominalismo e não aos pensadores individuais nominalistas, o ensino de Guilherme de Ockham sobre o tema merece maior exame, porque é justamente o pensamento e obras deste filósofo e verdadeiro jurista que definem o final do direito clássico medieval e o início do direito moderno, com o advento e "eclosão (...) do positivismo jurídico, e quanto à sua estrutura, da noção de direito subjetivo individual". ${ }^{19}$

Estudante e professor em Oxford do século XIV, vivendo os eventos do período da crise do sistema feudal, do início da ascensão burguesa e da formação dos estados nacionais, mudanças que vão exigir uma "nova via", traçada sobre a hegemonia do individual e uma revisão crítica da filosofia predominante até então, a Escolástica, Guilherme de Ockham é um apaixonado pela dialética, especialmente a aristotélica.

Ockham introduziu na filosofia ocidental uma inovadora visão que permitirá o aparecimento dentro da filosofia de um novo caminho a ser percorrido, distinto daquele até então conhecido pela filosofia medieval, uma "via nova" denominada de nominalismo moderno (o termo pode levar a uma diversidade de doutrinas ${ }^{20}$, mas tradicionalmente é compreendido como a doutrina que, contrária à tradição aristotélicatomista, chamada de corrente realista, e seu direito natural clássico ${ }^{21}$, nega a real existência dos universais, limitando a realidade ontológica ao singular) que "por si só, significa em filosofia do direito uma revolução radical"22.

Como comprovação desta justificação de Michel Villey, temos a conhecida discussão e defesa que Guilherme de Ockham fez, já naquela época, séculos antes do Iluminismo, quanto à divisão entre o poder eclesiástico e o poder político imperial, fundamentando sua proposta de rotura justamente no questionamento da legitimidade de cada poder em questão e da participação do povo na escolha de seus representantes políticos, temas que, apesar de não serem de exclusividade do pensamento de Guilherme de Ockham, trazem nele, um religioso que era, maior destaque pela sua

\footnotetext{
${ }^{19}$ Michel Villey, A formação do pensamento jurídico moderno, p. 221 e 225.

20 "Lors qu'on envisage uma 'enquete sur le nominalisme àtravers l'histoire de la philosophie (comme le propose la thèse de Jean Largeault), on se trouve devant une diversité de doctrines entre lês quelles l'assimilation semble purê ment nominale". - Dictionnaire de la philosophie, verbete.

${ }^{21}$ Esta tradição fundamenta o direito sobre algo exterior, a justa e objetiva relação da proporção e não sobre natureza do homem, como a modernidade do direito subjetivo apresentará.

${ }^{22}$ Michel Villey, A formação do pensamento jurídico moderno, p. 223.
} 
participação no abrandamento do poder eclesiástico e consequente fortalecimento do poder estatal.

De tal modo a filosofia jurídica do nominalismo de Guilherme de Ockham traz uma revolução que não é exagero algum afirmar que dele resulta antecipada determinada utilização consciente e sistemática do reconhecido contrato social do Iluminismo francês e do próprio positivismo jurídico, quando muitos colocam sua origem somente no século XIX.

Quanto ao contratualismo, decorre da análise que Ockham faz da noção de direito natural que pode apresentar três sentidos diversos: preceitos morais necessários para a razão; condição inicial da sociedade humana e, por fim, decorrências racionais da convenção estabelecida pelos homens ou por regras positivas humanamente colocadas.

É neste terceiro sentido que Ockham aposta: é o resultado racional de regras positivas sem relação com o estado de natureza universal e obrigatório.

Quanto ao positivismo jurídico, "um empréstimo que os juristas fizeram dos teólogos”23, se aceito e definido como a doutrina que, não aceitando o direito natural, promove como único direito aquele posto tendo como exclusiva fonte o Estado, edificando sobre a norma todo o conjunto da ordem jurídica, Guilherme de Ockham já dele se utiliza, em modo e em argumentações, seja quando apresenta que o Decálogo (ou seja, os dez mandamentos da lei de Deus como traz a Torá dos judeus e a Bíblia dos cristãos) é do mesmo modo um direito positivo, pois é posto tendo como exclusiva e única fonte, no caso, Deus; portanto, se trata de um direito positivo ainda que divino; seja quando analisa o já aludido embate entre o poder eclesiástico e o poder estatal, distinção e separação que se origina no direito positivo humano, criado pela vontade do imperador com fundamento na vontade popular. Em ambos os casos, as vontades estão entendidas como vontades individuais (e subjetivas), seja de Deus, seja do imperador, seja de cada súdito.

Do confronto dos seus estudos sobre a teologia e a moral, como religioso que era, com outros sobre a política e o jurídico, vislumbra-se o advento do direito subjetivo que, de igual modo, não é exagero afirmar é originário do nominalismo de Ockham.

Conflitante com o realismo e o direito natural clássico, a noção de direito subjetivo não é tão claro de definição como possa parecer ser. Seus efeitos não permitem

${ }^{23}$ Michel Villey, A formação do pensamento jurídico moderno, p. 247. 
que seja reduzido a mera possibilidade dada ao indivíduo pela norma de praticar ou não apontada e permitida conduta.

Todo este questionamento surge por decorrência da discussão entre o religioso e o papa da época, João XXII. Ockham, ao se opor às teses do papa que procurava com que os franciscanos tivessem a real propriedade daqueles bens dos quais detinham no seu uso diário ${ }^{24}$, busca defender a pobreza extrema da ordem franciscana. Mas, por frutos, fez mais que isto.

Ockham, para rebater as teses do papa, cria uma nova via para o direito, ou melhor, para o jus, que será, então, agora definido como um poder, uma possibilidade, uma faculdade, uma autoridade, um domínio do indivíduo visto como o ser único a ser considerado, evitando àquela definição da noção realista centrada na justa distribuição dos bens que se extrai da reflexão do direito grego-romano clássico: dar a cada um o que lhe é de direito ou de mérito, num sentido objetivo e externo ao indivíduo.

O direito não está mais nas coisas; está no indivíduo.

Os fundamento do pensamento clássico e seus argumentos a favor do papa, logicamente não poderiam ser aceitos por Ockham porque, se assim o fizesse, obrigatoriamente teria que chegar às mesmas conclusões e concordar com ele.

Ockham, então, procura e encontra outro caminho: evita a justa e proporcional distribuição, centrando suas argumentações não mais nos bens, mas no titular do direito (agora transformado em poder), ligando a vontade do individuo sobre o bem, ou seja, não um privilégio ou faculdade, mas uma autoridade da pretensão do indivíduo sobre a coisa e, assim, logo também, subjetivo, o fundamento da ideia moderna de direito, ou melhor, de jus.

Como se vê, está presente nesta ideia a perfeita representação da noção hodierna do direito subjetivo (poder de vontade) que se contradiz com a noção objetiva do pensamento clássico.

Contudo, muito embora seja tema de conversa frequente entre os juristas e os operadores do direito na sociedade jurídica hodierna, como já dito, não existe uma definição uníssona ou até mesmo aceita pela maioria de direito subjetivo.

${ }^{24}$ O papa João XXII, médico e jurista de formação, ao contrário de seus antecessores, declarava a impossibilidade dos franciscanos terem a utilização fática dos bens, mas não um direito seja de posse, seja de propriedade dos mesmos bens. Ou seja, na utilização do bem, necessariamente estava presente um direito, ainda nos bens consumíveis, como "um pedaço de queijo": como não comer um pedaço de um alimento que não é de sua propriedade? 
Quando dela se necessita, se toma alguma de caráter instrumental, voltada para os interesses particulares daqueles que carecem de sua noção para a elaboração e no sustento de um sistema.

Sem maiores ambiguidades, a noção de direito subjetivo faz a ligação entre a faculdade de um sujeito (poder) com mundo jurídico (direito), numa clara e elevada valorização do individuo, do individual, em face do coletivo e do social.

Ao invés de enfocar as atenções no social, como fez, por exemplo, Platão na República, o direito, agora, dedica a maior parte do seu zelo e atenção para o sujeito entendendo este como o indivíduo titular de direito.

O direito próprio do sujeito individual torna existente o direito subjetivo que inicialmente possui primeiramente a qualidade de ser ilimitado, mas que, depois, terá termos ao se chocar com o ilimitado do outro.

Vê-se que a subjetividade, característica daquilo que pertence e é pessoal do sujeito é resultado de processos e de experiências tidos dentro de uma história que possibilitam seu aparecimento e fixação numa sociedade típica e carente de sua necessidade.

Até a alta Idade Média, a ordem jurídica natural restava adormecida, assim como a doutrina aristotélica, se vivendo de um antigo e decadente (porquanto distorcidos para alguns autores) direito romano que, suplantado pela pregação cristã de origem paulina, preparou campo fértil para o individualismo jurídico que se realizará, como já dito, no pensamento nominalista de Guilherme de Ockham.

Tendo início com a questão da pobreza da ordem franciscana (e de toda a Igreja Romana) no século XIV em confronto com as determinações do governo do então papa João XXII que, formado em medicina e direito e de clara admiração pelo tomismo, é mais conhecido por pertencer à época da dita "crise dos papas de Avignon", período compreendido entre os anos de 1309 e 1377 quando os papas foram forçados a mudar a residência oficial e sede da Igreja de Roma para a cidade de Avignon, no sul da França e de ter sido eleito após uma manobra de Felipe V da França, Ockham, apoiando este último, centra sua atenção nos direitos defendidos por sua ordem religiosa, na tentativa de deitar abaixo o que chama de heresias doutrinais do papa, apontando a sua prática falaciosa.

Neste debate, por não ser um jurista de formação, mas amante da dialética e nominalista, Ockham traz a ousadia da inovação pela elaboração pessoal de suas 
definições ao direito e não simplesmente meras repetições de ditos por outros anteriores. Ensina que todo direito será especificado pelo seu conteúdo do poder $^{25}$ num provável arranjo formal de direitos.

"Parar de entender, pela palavra jus, a parte de bens que corresponde a cada um segundo a justiça, tanto natural como positiva, mas, como tende a fazer uso linguístico vulgar na Idade Média, entender por essa palavra um poder. Pois, então, torna-se possível distinguir, em relação a um mesmo bem, cujo uso nos é atribuído, o poder que vem da lei humana; separar a permissão de fazer uso desse bem, que todos os homens receberam de seu Criador, e o poder instituído pelo legislador temporal (...)"26.

Partindo de um campo novo, livre para uma nova via, contrária àquela oriunda dos vícios e dos ajustes conceituais decorrente da formação técnica jurídica até então repousada na visão realista dos escolásticos que se estabelecem sempre na visão geral da relação justa entre a pólis e o cidadão, Ockham, livre com a origem jurídica na vontade individual, inaugura um direito que se propõe a servir o indivíduo, porquanto, subjetivo.

Cada um, na liberdade plena da sua conduta, faça por seu próprio desejo, apartado de qualquer ordem de direito externa.

Esta é a nova realidade: o indivíduo, seja no direito positivo divino, seja no direito positivo humano, o que vai ocasionar a troca do direito natural clássico por outro, então contrário desde suas bases, gerando uma nova via para a noção ordem jurídica e social, particularmente favorável ao mundo moderno e seu apregoado sistema de vida.

Contudo, Guilherme de Ockham, apesar de tudo o que foi exposto, ainda carrega consigo o arcaísmo do pensamento medieval.

Ele ainda apoia (e muito) suas reflexões na autoridade do texto bíblico apresentada como verdade revelada e, portanto, uma verdade eterna e no pensamento filosófico principalmente de Aristóteles a quem chama de o Filósofo, apontando que, assim como faz Tomás de Aquino, não supera de uma vez a questão do enraizamento objetivo do conhecimento moral e jurídico.

\footnotetext{
${ }^{25}$ Michel Villey, A formação do pensamento jurídico moderno, p. 274.

${ }^{26}$ Ibidem, p. 266.
} 
Dado os passos iniciais, seguindo no seu caminho, superando de modo mais definitivo os ranços medievais, desenvolverão os estudos de Hobbes, Locke e Espinosa, entre outros.

Mais a frente na história, apoiados sobre as descobertas científicas, deliberações de questões mais práticas (com reflexos na política, na economia, na filosofia e outros campos) que aquelas outras que dominavam o mundo cultural de outrora, passam a ocupar de forma predominante as atenções da cultura humana.

Novos pensamentos surgem na discussão sobre a organização e disposição da natureza, tendo como seus ícones as figuras de Galileu Galilei e Copérnico e seus estudos desenvolvidos (a experiência de fatos singulares, a análise de um objeto em particular).

Ao mesmo tempo, no séc. XVII, o desenvolvimento burguês capitalista assume a pessoa não mais como indivíduo, não mais como a racional grega ou a criatura amada de um deus, mas agora como cidadão então considerado como aquele que, por si mesmo, por sua autônoma vontade, é portador da capacidade de constituir direitos e obrigações.

O direito natural moderno é criado para e pelo direito subjetivo ${ }^{27}$ que, vinculado ao uso racional da liberdade individual, foram "talhados para a busca estratégica de interesses privados e que configuram espaços legítimos para as liberdades de ação individuais, constituem o núcleo do direito moderno",28 que enfoca suas atenções para as qualidades, as faculdades e os direitos do indivíduo.

Desta forma, o sujeito de direito possui íntima relação com o pensamento moderno e, assim, cresce e floresce no entendimento do direito que aborda determinadas características de natureza social e racional do homem, também denominado de moderno direito subjetivo, cuja presença já está cunhada de forma latente nos ensinos de Grócio,

27 "O significado de S. como pertencente ao eu ou ao sujeito do homem é encontrado pela primeira vez em alguns escritores alemães do século XVIII (...). Já Baumgarten falava da 'fé considerada subjetivamente', em oposição à 'fé considerada objetivamente', que é o conjunto de crenças (...). Algumas décadas depois, discutia-se a beleza ou a verdade: seriam subjetivas ou objetivas? Entendia-se por objetiva 'uma propriedade dos objetos', e por S. 'uma representação da relação entre as coisas e nós, ou seja, uma relação com quem as pensa' (...). Foi desse uso do adjetivo que Kant extraiu o novo significado atribuído ao substantivo sujeito". - Nicola Abbagnano, Dicionário de filosofia, verberte.

${ }^{28}$ Jürgen Habermas, Direito e democracia - entre facticidade e validade, p. 47. 
Hobbes $^{29}$, Locke e, com certeza, em Leibniz ${ }^{30}$, no qual, o ser natural, por si, como elemento natural tão somente, não é portador de nenhum direito natural, devendo abstrairse no sujeito de direito para ser e ter.

Mais à frente, em Descartes, acontece o prelúdio da concepção moderna com a extrema opção de fundar toda a realidade sobre a subjetividade do ego cogito, tornando o entendimento humano o justificador de toda a realidade.

Portanto, somente na superação de um sujeito ainda devedor da natureza e do divino (que concorda em muito com o costume e com a tradição), se alcança o sujeito do direito moderno.

"No período moderno o homem procede à quebra com a ordenação de origem teleológica e metafísica fundado em sua autonomia e racionalidade. Desde modo, o homem moderno-iluminista permeado pelas ideias de liberdade perante o mundo, rompendo com a obediência a leis extrínsecas que não eram de sua autoria e às quais se subordinara durante a idade média. O ser humano, racional, teria a responsabilidade pelos destinos da história." ${ }^{31}$

Motivado na superação do fato, o direito moderno se forma do direito subjetivo, do homem mesmo, cuja imagem-ícone é a sua liberdade inalienável e eterna, entendida como o exercício racional da vontade em fazer ou não, numa abertura dele mesmo a uma perspectiva intersubjetiva ${ }^{32}$.

"Entramos, contudo, agora, no âmago do pensamento jurídico moderno. O próprio termo 'direito subjetivo' só data do século XIX. Mas a noção de direito concebido como o atributo de um sujeito (subjectum juris) e que existe exclusivamente só na vantagem deste sujeito remonta pelo menos ao século XIV. (...) Sua definição - Que é preciso entender precisamente por direito

29 "Um filósofo extraiu todas as consequências do nominalismo para o direito. Pode-se chama-lo o fundador da moderna filosofia do direito individualista, embora os princípios de seu sistema estejam já em Guillaume d'Occam e Duns Scot, desde o século XIV. É o grande filósofo inglês dos meados do século XVII, autor, entre outros livros, do Léviathan (1651)." - Michel Villey, Filosofia do direito: definições e fins do direito: os meios do direito, p. 117-118.

30 "Dicho de outro modo, Leibniz no solo descubre y nombra al sujeto de derecho, sino que, al trasladar la cuestión del sujeto desde el plano gnosiológico hasta el plano jurídico, también define las primeras lineas de una fundamentación intersubjetiva de la teoria del derecho" - Yves C. Zarka, La outra vía de la subjetividad, p. 36.

${ }^{31}$ Marcelo Benacchio in Sujeito no direito, p. 100.

${ }^{32}$ Yves C. Zarka, La outra vía de lasubjetividad, p. 36-37. 
subjetivo? (...) O direito apenas ligado ao seu sujeito. (...) o jus não mais evoca o dever que impõe a lei moral - uma licentia - ou uma liberdade - libertas. A ciência abstrata dos modernos isola no direito a vantagem que ele constituirá para o indivíduo." 33

Com a proteção da subjetividade humana típica da modernidade, como processo histórico-teórico, o sujeito (e não o ser natural ou a pessoa) passa a ser o centro de toda sociedade e de toda cultura produzida por estas relações que se fundamentam nas descobertas das ciências e na racionalidade, especialmente no direito.

De modo especial, temos o sujeito de direito, as pessoas dotadas de uma mesma racionalidade organizadora da realidade que constitui a sua estrutura imanente.

Superada a natureza das coisas grega e o divino medieval - na qual nem o dominador tinha poderes para criar as leis que não se fundassem nos desígnios divinos, cabe ao sujeito de direito, com sua razão e sua liberdade racional expressada em vontade, ser o novo fundamento sobre o qual o mundo se apoiará, a partir de então, na sua visão de cosmo.

A organização do poder, o positivar das leis, a forma de se viver como se estivesse "numa fina camada de gelo na qual não se pode parar", tudo irá se cravar e será orientado pelo e para o sujeito e seu subjetivismo que não poderá aceitar mais a desigualdade e a distinção entre os sujeitos e, por consequência, pregará aos quatro ventos a não diferença entre as várias etnias, religião, opção sexual, entre outros.

Ou seja, na mesma bandeira da liberdade repousa a igualdade do sujeito capaz.

Contudo, esta igualdade continua a ser manifestação do individualismo subjetivista, porquanto o sujeito de direito ainda é o único titular dos direitos universais ${ }^{34}$.

No exercício racional da liberdade e da igualdade típicas do pensamento moderno, nasce o sujeito de direito, tendo-as ligadas a sua própria personalidade não

\footnotetext{
${ }^{33}$ Michel Villey, na obra Filosofia do direito: definições e fins do direito: os meios do direito, especialmente p. 120 e 121.

${ }^{34}$ Cabe o alerta que temos no Poder Judiciário do Ceará e do Rio de Janeiro, por exemplo, habeas corpus impetrados em favor de chimpanzés mantidos em zoológicos, com base que na Constituição Federal que utiliza o termo "alguém" no seu texto sobre o instituto jurídico.
} 
existindo direito sem um sujeito como o seu titular, individualmente assim considerado, como dirá Kelsen ${ }^{35}$.

O sujeito de direito é uma instituição jurídica, uma criação do individual livre e igual que, de vontade autônoma ao meio que vive, com outros livres e iguais contrata, gerando obrigações entre as partes, no mais verdadeiro e fundamental contrato já firmado pela modernidade: pacta sund servanta.

Hobbes, Rousseau e Locke seguiram por esta trilha. Kant e mais recentemente Hegel também, ao lado dos iluministas franceses.

Porém, a história nos mostra que a racionalidade moderna não foi suficiente para garantir a igualdade, mesmo porque não nasceu para isto, mas para defender isolamento almejado pelo burguês.

É conhecido o dito popular: "Alguns são mais iguais que outros" em referência as regalias legais que os mais poderosos e detentores de privilégios recebem do Poder Judiciário em desfavor de outros “iguais”.

Também o holocausto pode ser considerado o marco símbolo deste fracasso.

Ou ainda antes dele se realizar, quando no início do domínio nazista, na utilização da racionalidade instrumental, como aponta a escola de Frankfurt, o povo judeu alemão na década de 1930, por força de lei, foram subjugados a uma segunda categoria de sujeito de direito (quase que "apátridas"), na qual não contavam sequer com a possibilidade de proteção do seu estado ${ }^{36}$.

Evidencia-se uma terrível contradição no instituto do sujeito de direito criado pela modernidade: embora o discurso seja diverso ${ }^{37}$, nascido para defender o ser natural, aquele definido como um corpo humano vivo dotado de capacidade de autoconsciência, este é perdido e afogado, porquanto por este o direito não irá se preocupar

\footnotetext{
${ }^{35}$ Hans Kelsen, Teoria geral do direito e do estado, p. 99.

${ }^{36}$ Sobre esse assunto, Marcelo Benacchio cita a obra de Ricardo Sayeg e Wagner Balera (O Capitalismo humanista) que apresenta inclusive uma cronologia das leis emitidas pelo estado alemão.

37 "Apesar de se apresentar como uma categoria formal, sujeito do direito corresponde a um sujeito psíquico e moral, que na perspectiva moderna liberal clássica é a pessoa humana." - Fabiana Cristina Severino in Sujeito no Direito, p.13.
} 
basicamente, mas irá sim se ocupar, pela abstração da instituição jurídica, do sujeito do direito criado pela ordem jurídica que lhe necessita e, por isso, alimenta e escora.

A pessoa somente terá valor por ser uma possibilidade de tornar sujeito do direito $^{38}$, valendo por aquilo que poderá ser, tendo como exemplo o nascituro na legislação pátria.

Desta forma, o direito moderno tem por base a concepção subjetiva do sujeito do direito, do qual mantém apenas uma relação inicial com a ideia de pessoa, na medida em que o direito é coligado com o uso singular da liberdade e da vontade de forma racional o que, ao invés de promover relações sociais, acarreta na superposição do eu sobre o outro, do individual e subjetivo sobre a comunidade e coletividade.

\section{b) A filosofia de Descartes, Kant e Hegel.}

\section{René Descartes}

Apesar de ser um tema controvertido, René Descartes é colocado como, senão o precursor, o fundador do racionalismo e da filosofia modernos pelo novo método que adota e empreende toda a construção do seu sistema sobre uma instituição plenamente subjetiva e estritamente individual. É conhecida sua famosa máxima: cogito, ergo sum. ${ }^{39}$

"Assim, porque os nossos sentidos nos enganam algumas vezes, eu quis supor que nada há que seja tal como ele o fazem imaginar. E porque há homens que se enganam ao raciocinar, até os mais simples temas (...) rejeitei como falsas, visto estar sujeito a enganar-me como qualquer outro, todas as razões de que até então me servira nas demonstrações. Finalmente, considerando que os pensamentos que temos quando acordados, nos podem ocorrer também quando dormimos, sem que neste caso nenhum seja verdadeiro, resolvi supor que tudo

\footnotetext{
38 “(...) em face da lei geral, é assegurada a toda pessoa humana uma esfera de autodeterminação em que ela pode se afirmar, de forma contínua, sujeito capaz de direitos e obrigações".- Fabiana Cristina Severino in Sujeito no direito, p.14-15.

${ }^{39}$ Michel Villey, Filosofia do direito, p. 111.
} 
o que até então encontrara acolhimento no meu espírito, não era verdadeiro que as ilusões dos meus sonhos. Mas, logo em seguida, notei que, enquanto assim queria pensar que tudo era falso, eu, que assim o pensava, necessariamente era alguma cousa. E notando que esta verdade - eu penso, logo existo, era tão firme e tão certa que todas as extravagantes suposições dos cépticos seriam impotentes para a abalar, julguei que a podia aceitar, sem escrúpulo, para primeiro princípio da filosofia que procurava". 40

Nascido na cidade de La Hayne (Turena) em 1596, Descartes estuda com os jesuítas de La Flèche, recebendo forte educação filosófica e científica nos moldes escolásticos. A princípio, a partir de 1618, dedica-se a vida militar, o que abandona já em 1620 para consagrar-se a sua paixão: a meditação científica. Após várias viagens, considerando que sua vocação era a procura pela verdade, rejeita a vida comunitária da família e do casamento e se retira para o seu "monastério" na Holanda onde, durante vinte anos, tendo por exclusividade os estudos, se dedica a sua cobiçada meditação, suas leituras e elaboração de suas obras. Em 1649, aceita um convite da rainha da Suécia e viaja para Estocolmo onde adoece, pois não possuía considerável vigor físico, morrendo em 1649 (ou 1650).

Descartes começa seu pensamento com uma indagação, uma dúvida metódica, gnoseológica e provisória que lhe servirá como marco inicial de tudo que construirá posteriormente.

Imposto pelo primeiro elemento que é o da intuição (virão outros: a análise, a síntese e a enumeração completa), todo conhecimento humano será submetido à dúvida, especialmente aqueles do campo sensível e o do racional, visto que claramente são passíveis de engano.

"O que me levou a pensar que era necessário procurar um outro método qualquer, que, compreendendo as vantagens desses três, fosse isento dos seus defeitos. E como a diversidade das leis serve muitas vezes de desculpa aos vícios, de sorte que um estado é bem melhor administrado, quando, tendo embora muito poucas, se aplicam rigorosamente; assim em vez desse grande número de preceitos que constituem a Lógica, julguei que me bastariam os

\footnotetext{
${ }^{40}$ Discurso do Método in Aloysio Ferraz Pereira, Textos de filosofia geral e de filosofia do direito, p. 132.
} 
quatro seguintes, contanto que tomasse a firme e constante resolução de não deixar uma só vez de os observar.

O primeiro, consistia em nunca aceitar como verdadeira qualquer cousa, sem a conhecer evidentemente como tal; isto é, evitar cuidadosamente a precipitação e a prevenção; não incluir nos meus juízos nada que se não apresentasse tão clara e tão distintamente ao meu espírito, que não tivesse nenhuma ocasião para o pôr em dúvida.

O segundo, dividir cada uma das dificuldades que tivesse de abordar no maior número possível de parcelas que fossem necessárias para melhor resolver.

O terceiro, conduzir por ordem os meus pensamentos, começando pelos objetos mais simples e mais fáceis de conhecer, para subir pouco a pouco, gradualmente até o conhecimento dos mais compostos; e admitindo mesmo certa ordem entre aqueles que não se prendem naturalmente uns aos outros.

E o último, fazer sempre enumerações tão completas e revisões tão gerais, que tivesse a certeza de nada omitir." ${ }^{11}$

Com isso, Descartes rompe com todo o conhecimento tradicional que recebera em sua formação acadêmica, especialmente a racional-escolástica, na qual vislumbra a possibilidade de incorrer em erro ou em incapacidade de conhecimento da verdade. Ele busca algo novo e o fato de ter escrito sua obra prima Discurso do Método em francês e não em latim comprova esta sua opinião.

É na dúvida que Descartes encontra a sua verdade primeira, imediata, intuitiva, que não pode ser atacada ou vencida e da qual nenhum pensamento pode escapar.

Traduzida tradicionalmente por res cogitans, mas que perfeitamente pode ser ego cogito, porque não se trata particularmente de alguma coisa (uma alma) que cogita, mas sim de um indivíduo que cogita, Descartes reconhece que cogitar (do latim cogitatio) se trata de uma atividade espiritual e psíquica própria do ser que desenvolve a atitude intelectual.

${ }^{41}$ Discurso do Método in Aloysio Ferraz Pereira, Textos de filosofia geral e de filosofia do direito, p. 130131. 
Tal pensamento crítico possui seu apoio maior e ele constrói toda a realidade sobre a subjetividade do cogito (res cogitans) individual. Terá forte influência na cultura francesa e filosófica, de modo especial em Kant, diretamente, e Hegel, indiretamente.

Afirmando que aquilo que faz a coisa ser o que ela é está na atividade da "coisa" que cogita (traduzido muitas vezes por pensamento), Descartes declara de forma aberta a superioridade do conhecimento intelectual (res cogitans) de caráter subjetivo sobre o conhecimento sensível (res extensa) de caráter objetivo. Esses últimos, inclusive, são transtornos para aqueles, e devem ser combatidos.

É neste ponto que Descartes supera o pensamento medieval no qual não se encontra a referida diversidade, mas é tido como um todo.

O sensível é instável e está contaminado pela incerteza e por contextos aleatórios, o que revela a falta de um juízo crítico de verdade que lhe garanta o desenvolver do conhecimento. E se o fundamento não está no exterior, onde buscar um novo ponto de sustento senão no subjetivo do indivíduo?

Mas não nele todo, porque os seus sentidos enganam. Centraliza o fundamento da verdade do conhecimento no entendimento humano (cogito, ergo sum) que apresenta como uma certeza intuitiva e infalível.

Seguindo o ambiente cultural que vive, destaca-se, portanto, o aspecto antropocêntrico de Descartes no qual não é mais Deus que dá a certeza da verdade, mas o homem em seu entendimento.

Descartes vive, diferente de Guilherme de Ockham, o pleno Renascimento, que, se não foi uma ruptura radical com a cultura medieval, traz consigo a plena superação do teocentrismo quando destaca o humanismo como centro da cultura.

Não mais Deus (eterno e absoluto), mas o homem (histórico e relativo).

Ao colocar o homem como centro, a história que se inaugura se encaminhará para a concretização da modernidade e de suas exigências, como cultura burguesa de prazer hedonista e individual, com apoio na divulgação nas artes e nas ciências. 
Ockham não tinha este ambiente, mas Descartes sim e, por isso, lhe foi possível romper com o costume arraigado, passado de geração em geração, eterno e absoluto, colocando a tradição como mero objeto de estudo.

O homem já não precisa de Deus para conhecer o bem e o mal; ele tem a si mesmo! O homem como personalidade se entende como indivíduo, campo aberto para o fortalecimento e instalação do direito subjetivo.

Em Descartes, o homem já não possui sua vida vinculada a uma ordem das coisas de forma eterna e absoluta, mas ele, agora, porque é único res cogitans, tem o direito-poder de dar à natureza a forma que lhe apreciar.

O homem deixa de ser figurante, e passa a ser protagonista.

Sujeito não é mais o tido como aquilo que está por baixo, mas é aquilo que, por baixo, dá sustentação, inclusive a ideia do Deus.

Não recebe mais passivamente as leis, mas as formula e dita conforme a sua razão (que agora ocupa o lugar da autoridade medieval) que lhe é típica; se torna o princípio e fim de todo o complexo normativo.

Tudo isto a partir de Ockham, uma nova via do direito na qual o sujeito de direito não é mais um espectador, um figurante ou ator nas comédias do mundo, mas é o seu protagonista.

Agora, sem a necessidade primeira de Deus para se conhecer a realidade, Descartes apresenta uma realidade nos limites do entendimento humano, retirando o elemento religioso como fundamento da realidade e consolidando a distinção entre fé, filosofia e direito.

Vivendo o Renascimento, é nesta visão compilada por Descartes que surge a relação intrínseca e ordenada entre o direito (jus) e o indivíduo como sujeito de direito que, moldada pela vontade humana, não é mais divina, mas antropocêntrica.

Hobbes, apesar de tecer críticas a Descartes, irá lhe seguir, especialmente no desenvolvimento da ordem da realidade humana.

Descartes assinala a existência de duas formas de moral: uma instrumental e provisória e outra sistemática e definitiva. 
A provisória é uma moral prática que consiste em seguir as leis e os costumes do local, porque, assim, se atende no bom viver enquanto o homem realiza a revisão crítica do saber e elabora uma nova construção do conhecimento.

Portanto, esta moral provisória é instrumental porque serve tão somente enquanto exerce a filosofia da dúvida metódica.

Muito embora necessária neste momento, esta moral não ultrapassa a possibilidade de acontecer ou não das relações entre os indivíduos dentro de uma mesma sociedade.

Mas, se é provisória é porque será substituída por outra definitiva, assim que a verdade for alcançada, construindo, inclusive, uma nova filosofia moral.

Saber se governar de forma prudente e sábia, visando uma solução racional do problema moral é a ciência final do homem, o sumo bem, na qual está a felicidade e o divino (muito embora a ideia de Deus irá proporcionar uma unidade racional ao sistema cartesiano, a estrutura universal somente será encontrada no individual). ${ }^{42}$

Vislumbra-se em Descartes uma raiz da ideia de emancipação, de autodependência que irá diferenciar o ser humano dos demais entes.

Possuindo esta autonomia e sendo capaz de determinar o que lhe é bom ou mal, o ser humano está dotado de uma qualidade que se denominará livre arbítrio e, pela vontade que expõe, o torna o substituto do Deus medieval, o divino no qual Ockham, ainda carrega consigo, com toda a sua autoridade e seus dogmas.

Talvez, devido a posição conservadora de Descartes quando se refere à política e ao direito, seus comentadores pouco apresentam sobre o seu pensamento político.

São conhecidos seus ditos quando escreve para Isabel da Baviera ${ }^{43}$ nos quais afirma que sua teoria não pode ser bem aplicada na política porque exigiria pessoas perfeitamente razoáveis, como deveriam ser os homens, assumindo uma posição muito parecida com a de Maquiavel, dando preferência, neste campo, a experiência, o que acaba

\footnotetext{
${ }^{42}$ Embora fosse católico praticante, Descartes não inclui a religião no seu sistema, pois ela não é possível em seu racionalismo imanentista.

43 Conhecida também por Princesa Palatina, era filha de Frederico, rei destronado da centro-européia Boêmia, uma mulher inteligente e culta, com a qual Descartes manteve íntima amizade.
} 
reduzindo a política e a moral a sua utilidade e tendo o direito à força regulada tão somente por uma ética subjetiva.

Deste modo, não se pode deixar de perceber que é no pensamento de Descartes que está a fonte daquela moral que se verificará fortificada posteriormente em Kant que, vivendo em plena ascensão da burguesia e dos seus preceitos liberais ${ }^{44}$, afirmará que a ação livre é aquela que está em consonância com o juízo racional individual que irá estabelecê-lo como verdadeiro (age de tal maneira que o teu comportamento possa servir de modelos para outros).

\section{Immanuel Kant}

Subjetivo e subjetividade se relacionam com a noção de consciência e a racionalidade, como vista por Kant, orientou todo o percurso da filosofia moderna. Este caminhar sofre uma ruptura quando pensamos na fenomenologia heideggeriana.

Se Descartes é por muitos considerado o fundador da filosofia moderna, Immanuel Kant é o fundador da filosofia contemporânea.

Seu pensamento, denominado de criticismo, influencia intensamente todo o que lhe é posterior, abrindo caminhos para ao menos duas correntes contraditórias e combatentes: o idealismo de Hegel, que radicaliza os ensinos de Kant e, outra, o positivismo de Comte que, embora tente lhe ser contrária, percorre os mesmos caminhos da imanência ${ }^{45}$.

${ }^{44}$ Alysson Leandro Mascaro, Filosofia do Direito, p. 208.

${ }^{45}$ Nicola Abbagnano apresenta três definições para o termo imanência: primeiro, "presença da finalidade da ação na ação ou do resultado de uma operação qualquer na operação; $2 .{ }^{0}$ limitação do uso de certos princípios à experiência possível e recusa em admitir conhecimentos autênticos que superem os limites de semelhante experiência; $3{ }^{0}$ resolução da realidade na consciência." E mais adiante pondera que: "O segundo significado desse termo corresponde ao emprego que Kant faz do adjetivo, chamando de imanentes 'os princípios cuja aplicação se tem em tudo e por tudo dentro dos limites da experiência possível', contrapondo-se, portanto, aos princípios 'transcendentes', que ultrapassam esses limites (...) Neste sentido, I. significa limitação do emprego de certos princípios ao domínio da experiência possível, e renúncia a estendê-los além dele. (...) Comum a esses três significados do termo é o conceitos de imanente como tudo que, fazendo parte da-substância de uma coisa, não subsiste fora dessa coisa." Dicionário de Filosofia, verbete. 
Apresentando-se como uma investigação sobre as possibilidades do conhecimento pela razão e síntese entre o empirismo e o racionalismo, Nicola Abbagnano traz como sendo os pontos básicos do criticismo kantiano:

"1- Formulação crítica (v.) do problema filosófico e, portanto, condenação da metafísica como esfera de problemas que estão além das possibilidades da razão humana. 2- Determinação da tarefa da filosofia como reflexão sobre a ciência e, em geral, sobre as atividades humanas, a fim de determinar as condições que garantem (e limitam) a validade da ciência e, em geral, das atividades humanas. 3- Distinção fundamental, no domínio do conhecimento, entre os problemas relativos à origem e ao desenvolvimento do conhecimento no homem e o problema da validade do próprio conhecimento, isto é, distinção entre o domínio da psicologia (...) e o domínio lógicotranscendental ou lógico-objetivo, onde tem lugar a questão de iure da validade do conhecimento, insolúvel no terreno de facto". ${ }^{46}$

Immanuel $^{47}$ Kant nasce em 1724 na Prússia Oriental, numa família de capacidade econômica modesta. Recebe educação de cunho pietista ${ }^{48}$ que marca sua pessoa.

Na faculdade de filosofia estuda Leibniz e Wolff, dominantes na época, além da matemática de Newton. Depois, estuda os empiristas ingleses, destacando Rousseau, Locke e Hume ao qual aponta como aquele que o despertou do conhecido sonho dogmático que nada mais seria do que o racionalismo. Este período deve ser localizado próximo ao ano de 1766, quando publica uma obra em que relaciona, na sua narrativa, os sonhos de um visionário sueco da época com a metafísica ${ }^{49}$.

Deixando o período pré-crítico, Kant publica em 1781 a primeira das suas grandes obras, Crítica da Razão Pura, na qual examina a razão humana e sustenta a sua capacidade em edificar uma ciência, contudo não metafísica, obra que o firmará como filósofo no mundo cultural.

\footnotetext{
${ }^{46}$ Dicionário de Filosofia, verbete.

${ }^{47}$ Não há unanimidade quanto a grafia do primeiro nome de Kant.

${ }^{48} \mathrm{O}$ pietismo foi uma reação contra o estado de coisas no interior da igreja luterana que, como a época descuidava da dimensão pessoal da religião, valoriza as experiências individuais do crente, influenciando no surgimento outros movimentos protestantes, entre eles o atual pentecostalismo.

${ }^{49}$ A obra de Kant: Os sonhos de um visionário iluminado pelos sonhos da metafísica.
} 
Alvo de lendas e histórias (como a de que de fazia rotineiros passeios onde saída e chegada em sua casa com precisão de cronômetro), nunca se afastou mais que algumas dezenas de quilômetros de sua cidade natal.

Nela nasce, se forma, leciona na Universidade de Königsberg e, após uma vida dedicada inteiramente aos estudos e ao ensino, vivendo sozinho e não constituindo uma família, morre com oitenta anos, em 1804.

De uma forma histórica geral, Kant vive ainda a ascensão da cultura burguesa e como tal, a Europa carece de apoderar-se de novos pensamentos que darão fundamentos a esta nova maneira de pensar que a cultura liberal exige.

Para o tema deste trabalho, torna-se indispensável encarar o trabalho levado a termo por Kant, na síntese que realiza da subjetividade moderna, porque seu pensamento irá apontar para contradições estruturais dessa subjetividade.

Diferente que Ockham que coloca a virtude como um acordo entre a vontade divina e a do indivíduo, em Kant, a ação moral e virtuosa do homem tem seus limites na sua própria vontade racional.

Para todo o pensamento que lhe posterior, a virtude se estabelece num acordo da vontade do indivíduo humano consigo mesmo, ou seja, como norma exclusiva da sua própria vontade racional.

Enfim, se tem a autonomia do sujeito, ainda que na sua versão de protótipo, em construção, e não de modo finalizada.

Em conceitos gerais, depois de introduzir o tema com forte influência de Hume e de concluir numa posição típica do ceticismo, a Crítica da Razão Pura, Kant desenvolve uma investigação sobre a capacidade cognitiva da razão humana.

Trata-se, portanto, de uma obra que trabalha sobre uma teoria do conhecimento, traçando um caminho em três pontos: sobre estética transcendental que aborda o conhecimento sensível governado pela intuição; sobre a analítica transcendental que debate o conhecimento inteligível, mas ainda com base na experiência, governado pelo intelectoe; sobre a dialética transcendental que discute o conhecimento transcendente à experiência governado pela razão, momento no qual destrói a metafísica como construção do espírito humano. 
Tudo irá culminar na famosa "revolução copernicana" (de cunho idealista $)^{50}$ que tanto elogiam Kant e que consiste em ter colocado que o indivíduo não mais reflete as coisas de seu conhecimento, mas as estabelece, ou seja, o objeto não se torna mais o centro do conhecimento, mas, em seu lugar, foi colocado, agora sim, o sujeito.

Não é o sujeito que depende do objeto, mas ao contrário, este é que depende daquele: tudo é subjetivo.

Neste ponto, Kant suplanta com facilidade a posição de Hegel que ainda colocou no divino a responsabilidade de unificar todo do seu sistema.

Na outra obra, Crítica da Razão Prática, Kant busca erguer uma nova metafísica em substituição daquela outra por ele destruída.

Nesta nova metafísica, a moralidade da ação é dada por um imperativo que é categórico, ou seja, se impõe de uma maneira que, além de ser absoluta e necessária, não está sujeita a nenhuma condição, pois objetiva, valendo para todos os racionais, a ponto de coagir a sua vontade.

Este imperativo categórico se traduz de diversas maneiras ao longo das obras de Kant, mas pode ser apresentado como sendo o agir de tal maneira como se a máxima da ação pudesse se tornar, através da vontade individual, em lei universal.

Embora possua um aspecto de universalidade, este se refere tão somente que o imperativo resulta da ação moral incondicionada, ou seja, a ação é moral e intrinsecamente correta em si mesma, e não por obrigação a outro fim buscado pelo sujeito que, desta forma, a condiciona; é independente de relação ou valoração objetiva.

Pode-se afirmar que, portanto, este imperativo nada mais é que um dever, bom em si mesmo e fruto da razão humana.

"Para o homem, norma da razão humana é uma ordem, pois a vontade humana não é a faculdade de escolher apenas $o$ que a razão reconhece como praticamente necessário, ou seja, como bom. Se assim fosse, a norma da razão

50 Alysson Leandro Mascaro citando Otfied Höffe: “A revolução copernicana de Kant significa que os objetos do conhecimento objetivo não aparecem por si mesmos, mas eles devem ser trazidos à luz pelo sujeito (transcendental). Por isso, eles não podem mais ser considerados como coisas que existem em si, mas como fenômenos. Com a mudança do fundamento da objetividade, a teoria do objeto, a ontologia, passa a depender de uma teoria do sujeito, de modo que não pode mais haver uma ontologia autônoma." Filosofia do direito, p. 211. 
não teria caráter coativo e não seria uma ordem. Isso acontece com os seres dotados de vontade santa, de uma vontade que está necessariamente de acordo com a razão e que só pode escolher o que é racional. Mas, como o homem pode escolher também segundo a inclinação sensível, a lei da razão assume para ele a forma de ordem e por isso sua expressão é um imperativo". ${ }^{51}$

Este fruto da razão humana não é somente um formulador das leis que se organiza por meio das sínteses do mundo sensível ou, como aponta Kant, dos fenômenos, ou seja, aquilo que se apresenta aos sentidos do sujeito que conhece; é também do mundo absoluto, ou como diz Kant, dos noumenons (ou seja, a coisa em si), porque é a razão prática aquela que institui os valores morais imperativos.

Verifica-se, portanto, embora Kant tenha sido um religioso praticante, sua filosofia de cunho imanente e idealista tende para um ateísmo, no qual a figura de Deus é completamente substituída pela a do homem, que passa a ser o local onde se encontra as definições das normas para seu agir.

Em Kant, seguindo Descartes, toda a sistematicidade da realidade, inclusive a estrutura da realidade da natureza, é estabelecida pela racionalidade humana.

Também o direito proposto por Kant como sendo aquele legítimo é o direito da razão, ou que não afronta seus preceitos.

Não mais o direito divino, nem mais o direito natural como aquele que resta presente na natureza, nem aquele volutivo, mas o direito natural da razão, oriundo das vontades livres, fraternas e igualitárias em relação entre aqueles que serão denominados num futuro próximo (em Hegel) de sujeitos de direito.

Isto porque, muito embora Kant não faça referência expressa ao sujeito de direito em suas obras, pois no momento histórico que vive, como dito, o sujeito de direito não se tornou ainda um dos centros de atenção do pensamento jurídico, ocupando uma posição secundária, todavia, colocando como centro do seu pensamento práticojurídico o dever do imperativo categórico, se percebe que o caminho para a presença e desenvolvimento do sujeito de direito e da subjetividade na realidade está traçada, na trilha do desenvolvimento que se encontra na noção de sujeito e indivíduo.

${ }^{51}$ Crítica da Razão Prática, in Nicola Abbagnano, Dicionário de Filosofia, verbete. 
Apesar de todo o esforço feito por Kant, continua presente na sua filosofia traços de uma filosofia medieval, embora já decadente, naquilo que Kant irá apontar em seus escritos como algo que lhe é incoerente, porque ainda continua fora ao sujeito e possui uma realidade que lhe é externa: os conhecidos postulados da razão prática, numa tentativa de salvar os conceitos tradicionais eu lhe são caros, talvez como resultados das suas convicções religiosas pessoais, como também as morais.

Os postulados da razão prática são Deus, a alma e a liberdade, alcançadas pelo fato de que a moralidade é - diversa do restante de seu pensamento - um valor absoluto, mas não pertencente ao mundo dos fenômenos.

A partir deles postulados, Kant se socorre de outro mundo (o das coisas em si, onde a imortalidade da alma é uma realidade) na qual a virtude é recompensada com a felicidade por um Deus que não é mais um legislador, mas um juiz.

Neste mundo "superior", o juízo moral somente é possível com a liberdade da vontade.

Com eles, Kant demonstra que seu pensamento ainda está encarcerado por qualquer coisa que ele tenta se livrar. Trata-se um resquício do pré-modernismo.

Entretanto, Kant anda um bom trecho do percurso e deixa evidente que o jurídico se configura na relação entre sujeitos e, após, envolvendo seus objetos e não mais na incoerente relação entre sujeito e seus objetos.

Apesar do sujeito em Kant não estar ligado exclusivamente a sua vontade particular, subjetiva, mas ligado sim à razão que deve governá-lo de forma imperativa, categórica e, por consequência, objetiva - e, portanto, Kant dá maior destaque ao dever racional objetivo que ao poder subjetivo, como se observa na sua filosofia, o centro do seu pensamento moral reside no sujeito que atravessou as portas da sua emancipação.

Se o sujeito continua ainda submetido à racionalidade universal e objetiva do imperativo categórico, fruto do cogito, não se pode perder que se trata de um adequado ego cogito que se torna universal.

A razão subjetiva pode ser identificada com a transcendente razão universal e o imperativo que se apresenta para a humanidade, parte do sujeito. 
Eis, como dito, o eixo principal da filosofia moral de Kant: embora retirado da imanência do sujeito livre e autônomo, o imperativo categórico é independente da sua experiência, sujeito às ordens da razão, por isso é verdadeiro a priori e, por resultado, universal

Do contrário, este imperativo estaria sujeito às tendências naturais e experiências sensíveis aleatórias do sujeito (ou seja, seria a posteriori), o que Kant já se colocou totalmente distante desde a Critica da Razão Pura, demonstrando que a verdade do conhecimento somente pode estar no a priori.

Ao contrário do categórico que é um dever moral incondicionado, o outro imperativo, o hipotético, não se trata de obrigação, mas de condição para chegar a determinado fim, dependendo de finalidade(s) maior(es) para ser realizada e está sempre sujeita a experiência. São os meros conselhos de prudência.

Voltando para o imperativo categórico, ele versa de uma universalização de um dever moral que foi, em seu início, subjetivo.

Verifica-se, portanto, que é a universalidade a exigência crítica racional do imperativo e não tanto o seu conteúdo.

Se se costuma afirmar que o dever moral de Kant não está sujeito a nenhuma condição (e realmente é incondicionada se se entender como tal condição algum fim subjetivo), melhor seria dizer que, na verdade, ele é condicionado somente um fator: aquele do "que se torne lei universal", ou seja, deve necessariamente, por exigência da racionalidade, se objetivar como uma lei universal.

$\mathrm{Na}$ formulação do imperativo categórico, Kant não se preocupa com o experimentado da ação (que é o seu conteúdo).

Apesar de continuar tendo como ponto de partida ainda o sujeito e sua atuação individual, a regra obtida pelo dever moral se torna independente da vontade subjetiva, donde se originou, na medida em passa a possuir uma forma universal e objetiva, por exigência da racionalidade e, agora sim, independente de fins subjetivos, fim em si mesmo.

Depois de vestir a forma do universal, aquele dever moral, que fora de início subjetivo, então, em conformidade com a razão, se torna imperativo que se estende a 
todos e atua como exigência definitiva sobre a ação de um e de todos que são racionais, eliminando a arbitrariedade da vontade particular de fins subjetivos.

Mas o imperativo categórico não atuará sobre o sujeito e todos outros racionais como algo que lhe é de obrigação externa.

Se assim for, será a imposição da arbitrariedade de um sobre os demais que lhe são submissos.

Reconhecendo o fim em si mesmo do imperativo categórico, a vontade do sujeito (e de cada dos sujeitos) reconhece seu dever objetivo, concordando com ele, fazendo com que o seu dever moral proceda de uma mesma e então única vontade.

Concordando com o imperativo, o sujeito concorda consigo mesmo, como ser racional é.

Concordando com o imperativo, o sujeito submete a sua vontade subjetiva a racionalidade que faz desta vontade, se revestida da forma da universalidade, a legislação objetiva do dever moral.

Colocar-se na posição de obediente ao imperativo categórico, entendendo racionalmente o seu fim em si mesmo, é o mesmo que manter a liberdade (que apesar de não poder ser conhecida, pode ser pressuposta), conservando intacto aquilo que Kant denomina como sendo o princípio da autonomia da vontade.

Este princípio afirma a capacidade que a razão pura tem de ser, ela mesma, a promotora e a seguidora de seus princípios práticos considerados válidos para todo e qualquer ser racional $^{52}$, ou seja, leis práticas de validade objetiva, o que se posiciona no núcleo da teoria da moral kantiana, já que a autonomia da vontade é condição necessária para a ética.

Como se vê, a teoria moral de Kant é dependente da probabilidade da vontade subjetiva ser, pela racionalidade e por ela mesma, o único fundamento de determinação da vontade universal.

\footnotetext{
${ }^{52}$ De forma diferente, os princípios práticos que guardam a sua validade conhecida pelo sujeito apenas para a sua vontade individual são chamados princípios práticos subjetivos ou máximas.
} 
Uma razão pura portadora de princípios práticos ou de leis práticas é antecedente necessário da autonomia. Para ser livre, o sujeito deve agir com autonomia, ou seja, agir moralmente.

Se assim fizer, se pode arriscar ser inclusive desnecessário o imperativo categórico que se coloca somente para aqueles sujeitos que ficar aquém na sua autonomia. É a razão que assinala a disposição do sujeito para a moral.

Daí a distinção que Kant faz entre pessoas e coisas.

Coisas são os seres que não dependem da vontade do sujeito, mas da própria natureza, são irracionais e, por isso, possuem um valor relativo como meio. As coisas não têm autonomia e liberdade e não agem moralmente.

Já as pessoas (ou sujeitos), por serem racionais, são distintas das coisas na natureza, sendo aptos a se tornarem fins em si mesmos.

Como se vê, seguindo ainda o princípio da autonomia da vontade, a ação moral traz íntima correlação com a noção de liberdade como aplicada por Kant.

Tanto a definição negativa - que afirma que livre é a vontade que não é sujeita pelas coisas (que são irracionais), como aquela outra positiva - que diz que a vontade é determinada por sua própria racionalidade (portanto, pessoas), ambas apontam que vontade autônoma é também livre, porque é determinada por si própria e com fim em si mesmo.

Mesmo aqui é a racionalidade o elemento diferenciador que possibilita que as pessoas se dirijam tanto para autonomia, como para a liberdade.

Somente as pessoas (que podemos chamar igualmente de sujeitos), que são aqueles seres portadores de uma vontade prática, porquanto racionais, são livres e autônomas.

Se fiel ao ensino de Kant, uma coisa livre e autônoma é, na verdade, uma contradição, uma incoerência e até mesmo uma impossibilidade, por não ser racional e ser apenas meio.

A liberdade e a autonomia do sujeito se dão no mundo da moral universal que é próprio às pessoas. 
Neste ponto poderia surgir a pergunta: fazendo esta distinção entre coisas e pessoas, Kant realiza uma dicotomia de realidades, aos moldes de Platão, separando sensível do inteligível? Será correto o entendimento de separação entre a realidade das coisas e a das pessoas, da arbitrariedade e da racionalidade, da sujeição ao sensível e da autonomia e liberdade do inteligível? Kant vai, então, se apoiar numa espécie de "crença" em algo que se tem como certeza, mas sem provas da sua realidade, mesmo que seja esta racional? Apesar de compartilhar do mesmo imperativo categórico, será que esta dicotomia se apresentará também entre o direito e a moral? Ou seriam apenas duas manifestações de uma mesma realidade?

Sem dúvida alguma, a liberdade do sujeito não se perfaz no mundo do sensível, mas sim no do racional e do inteligível, o que possibilita a todos os indivíduos atingirem tal realidade.

Todos podem alcançar a situação moral racional, seja pela atuação do imperativo categórico, seja pela atuação da sua vontade de razão prática.

O problema está no relacionamento entre estas liberdades a que todos podem alcançar.

No mundo da moral, enquanto se localiza a argumentação tão somente num único sujeito, como que universal, o problema do relacionamento não é um problema.

Já no mundo do direito, é questão central o que impossibilita o simples passar de um campo ao outro.

E Kant não pode abandonar o fundamento, que construiu ao longo de todas suas principais obras, que é a da ascendência da vontade prática do racional a priori.

Se alguém livremente se colocar como escravo de outro, se mantém intacta a liberdade de ambos? Como isto seria possível se se ter uma pessoa como escravo não é o mesmo que transformá-la numa coisa em relação ao senhor?

Não se pode esquecer que Kant está empenhado em arquitetar um direito que seja aquele procurado - ao menos em parte - como novo fundamento jurídico pela cultura burguesa em ascensão. 
Para isso, ele resolve (ou tenta resolver) mostrando que o direito não se estabelece como a moral com base na vontade prática do sujeito.

Ao contrário, a legalidade do direito não se apoia exatamente na vontade prática do subjetivo. Ela lhe pode ser externa, como numa ação de uma vontade que foi definida como consenso para as relações entre de liberdades e autonomias subjetivas, desde que aconteça a influência de uma sobre a outra.

Quando se foca no direito, nota-se uma evidente contradição na teoria kantiana: feita de sujeitos livres, permite a atuação legalidade na sociedade, ou seja, admite a condição de se estar sujeito a vontade de outro.

Para Kant, assim como para os filósofos contratualistas modernos, é a razão autônoma dos próprios indivíduos humanos que fundamenta a vontade geral da sociedade.

$\mathrm{O}$ direito desvincula-se de qualquer base transcendente, para ter sua origem nos indivíduos para, a seguir, tornar-se dependente da vontade autônoma e racional destes.

O imperativo categórico é transcendente e deve gerar a comunhão racional dos seres. Mas esta comunhão não supera a própria racionalidade.

A singular contradição é resolvida com a noção de que mesmo que esta vontade presente no direito seja externa, ela será sempre uma projeção da racionalidade desujeitos autônomos.

O direito, portanto, é também um dever moral, mas que se preocupa das relações entre liberdades, cujo centro continua a ser, em ambos, a razão.

Permitir o convívio das liberdades das autonomias de cada sujeito, em relação, de tal modo que uma não dificulte a atuação da do outro é a finalidade do direito.

O sujeito de direito, em Kant, continua a ser o sujeito moral livre e, portanto, autônomo que, compreende racionalmente a limitação da sua liberdade exterior como condição para a possibilidade da coexistência da relação entre os sujeitos.

Desde modo, até mesmo o emprego de uma ação coercitiva (completamente externa, portanto) encontra sua justificativa racional. 
A coerção é na verdade uma manifestação da liberdade inerente a todos os sujeitos porque protege e sustenta, especialmente destinada para aqueles que ainda necessitam do imperativo categórico na atuação da sua moral, a coexistência da autonomia de sujeitos de direitos que são livres em si.

Ao que parece, Kant prega a crença de dois mundos distintos, ou ao menos, de dois aspectos da mesma realidade. No embasamento destes mundos (exterior e interior) ou destas realidades (não racional e racional) está firme o sujeito subjetivo como único capaz da vontade prática e da ação moral.

E aquele que se coloca na situação de escravo de outro, muito embora seja como uma coisa para o seu senhor, própria de ter a sua posse declarada e até mesmo reclamada perante terceiros, ainda preserva sua condição de sujeito livre porque, como foi assim que ele quis, não entrega (ou vende) ao outro o seu sujeito moral, mas tão apenas os seus serviços.

Numa contradição, aquele que se colocou na condição de servo é, ao mesmo tempo, sujeito livre para si (e, portanto, não menos sujeito de direito que o senhor) e uma coisa para o seu senhor.

Com o "todos são iguais" receitado pela legislação, a economia burguesa está no rumo adequado para a justificação racional da venda da mão de obra e da exploração do trabalhador pelo capital.

\section{Georg Wilhelm Friedrich Hegel}

Radicalizando o idealismo proposto por Kant, surge a figura de Hegel cuja máxima é por todos conhecida: todo ou o que é racional é real e todo ou o que é real é racional.

Com este dito, Hegel se afasta daqueles que atrelam a metafísica com a realidade vivida, porque, para ele, a realidade e tudo que nela se encontra possuem a qualidade única de ser histórica inclusa numa doutrina que nega qualquer ser ou ainda 
qualquer manifestação deste mesmo ser fora da consciência ou da autoconsciência racionalmente colocada (imanência).

Hegel, apesar de afrontar Kant em muitas ocasiões (como faz, por exemplo, com a negação da ideia de dicotomia entre a realidade das coisas e a das pessoas), parte e coloca como alicerce da sua filosofia o pensamento daquele, especialmente a ideia da síntese a priori, na qual a realidade, como um vir-a-ser dialético, e toda a sua atividade, reduzida ao âmbito da experiência ${ }^{53}$, são concebidas para a plena realização do Espírito.

Niccola Abbagnano apresenta as várias definições para o termo "Espírito" (alma racional ou intelecto, pneuma, substância incorpórea e outros), indicando quanto se refere a Hegel:

"Foi só com Hegel que se teve uma especificação diferente da noção de E., com as noções de E. objetivo e E. absoluto. Se por E. subjetivo ele entende o E. finito, ou seja, alma, intelecto ou razão (E. no significado cartesiano do termo) (Ene, §386), por E. objetivo ele entende as instituições fundamentais do mundo humano, quais sejam, direito, moralidade e eticidade, e por E. absoluto entende o mundo da arte, da religião e da filosofia. Nessas duas concepções, o E. deixou de ser atividade subjetiva para tornar-se realidade histórica, mundo de valores. Enquanto E. objetivo é o mundo das instituições jurídicas, sociais e históricas que culmina na eticidade (que compreende as três principais instituições históricas: família, sociedade civil e Estado), o E. absoluto é o mundo da Autoconsciência, que se revela a si mesma nas produções superiores, que são a arte, a religião e a filosofia (Ibid., §§ 486, 553). Para Hegel, as três formas de E. são manifestações da Ideia, da Razão infinita, mas é só no E. objetivo e no E. absoluto que a Ideia ou Razão se realiza plenamente ou chega à manifestação acabada ou adequada. Essas noções caracterizam o idealismo romântico de inspiração hegeliana, que identificou E. com sujeito absoluto ou eu universal, $(\ldots)^{54,}$

\footnotetext{
${ }^{53}$ Se toda a realidade está reduzida ao âmbito da experiência e nada lhe transcende, Hegel completará o ateísmo proposto por Kant.

${ }^{54}$ Dicionário de Filosofia, verbete.
} 
Apesar de poucas décadas os separarem, a realidade histórica de Hegel é bem diferente daquela de Kant, que ainda guerreava contra o estado absolutista típico do feudalismo que apesar de moribundo, sobreviva.

O Iluminismo, que defendia os interesses os interesses burgueses, se tornou o sinal de nascença do novo modo de vida do sistema capitalismo que, com o seu prolatado individualismo, mostrava que a cultura burguesa não era mais algo em desenvolvimento.

Faz-se necessária, agora mais do que nunca, novas teorias, ideias e explicações que justifiquem e ampare esta novidade de realidade que se apresenta como uma construção da burguesia, que consolida a economia capitalista de tal maneira que, se precisava, de se ter princípios que, ao oferecer uma nova interpretação da realidade, colocassem, de uma forma racional, o indivíduo como sujeito de direito proprietário de suas coisas - até mesmo de seu corpo e força de trabalho (como se coisas fossem) e livre, para que pudesse, com seus iguais, se relacionar, contratar e negociar e, assim, legitimar a acumulação de bens por meio do direito subjetivo.

Alysson Leandro Mascaro aponta de modo claro a situação da filosofia de Hegel:

"O pensamento de Hegel representa a grande virada em relação à tradição da filosofia do direito moderno. Numa trilha que vai de Locke a Kant, o Iluminismo insiste em conteúdos universais do direito, extraídos da razão individual. Contra a realidade absolutista, os burgueses iluministas apregoavam o direito natural da razão. Mas Hegel, em outra etapa, já na virada para o século XIX, não trata de opor, em face do Estado, algum direito da razão individual. O Estado já é burguês. A própria burguesia, que defendia um direito universalista, consolidava-se no poder de cada Estado nacional e se adaptava às contingências específicas valendo-se do direito positivo que agora the pertencia. A burguesia, que passara séculos defendendo uma filosofia do direito jusracionalista, agora era juspositivista. Sua visão filosófica, que se pretendia eterna e universal, paradoxalmente mudou. (...) (Hegel) pode apreender as transformações de seu mundo constituindo uma teoria geral que se centra, da mesma forma que seu tempo, no problema filosófico da 
transformação, da história, da mudança. É justamente nessa processualidade que se funda a base do pensamento hegeliano." ${ }^{.55}$.

Ou seja, o que Kant vivia em expectativa, Hegel vive em realidade.

Hegel nasce em Stuttgart em 1770. De início estuda teologia e filosofia e defende ideias simpatizantes ao pensamento do amigo Fichte e de Schelling, aos quais abandona pouco tempo depois. Pessoa de afinada inteligência e vasta cultura, Hegel adquire fama como professor nas Universidades de Heidelberg e, depois, de Berlim, cargo que ocupou até a sua morte em 1831. Pesa-lhe a acusação de desfigurar os fatos para adaptá-los ao esquema lógico do seu sistema e aos seus interesses. Na política e no direito, fica conhecido pela defesa das disposições absolutistas do estado prussiano.

Não se pode tratar de Hegel se antes não abordar sua noção de dialética.

Se Hegel coloca que tudo está reduzido ao âmbito da experiência, ele carecia de encontrar uma maneira de elevar a realidade da experiência à ordem absoluta, a fim de conseguir desvendar a racionalidade absoluta da realidade da experiência.

O caminho escolhido foi o da percepção desta racionalidade absoluta da realidade da experiência como um contínuo e absoluto devir, no qual a tese gera a antítese, concluindo numa síntese, que se tornará uma nova tese, que vai gerar uma nova antítese, com nova síntese, num contínuo vir-a-ser absoluto e dialético.

Novamente Abbagnano ajuda na compreensão do termo "devir":

"Devir ou vir-a-ser. 2. Uma forma particular de mudança, a mudança absoluta ou substancial que vai do nada ao ser ou do ser ao nada. Esse é o conceito de Aristóteles e Hegel (...) Conceito não muito diferente foi expresso por Hegel ao dizer que o D. é a unidade do ser e do nada. 'O D.', disse Hegel, 'é a verdadeira expressão do resultado de ser e nada, como unidade destes: não é só a unidade do ser e do nada, mas é a inquietação em si’ (Ene, §88). Na grande Lógica, Hegel ilustrou e defendeu longamente o significado desta definição: 'A verdadeira importância da proposição: 'nada vem do nada, nada é dada', está em sua oposição ao devir em geral e, portanto, também à criação do mundo a partir do nada. Aqueles que se acaloram defendendo a proposição de que o

${ }^{55}$ Filosofia do direito, p. 237-238. 
nada é o nada, não se aperceberam de que nisso coincidem com o panteísmo abstrato dos eleatas e substancialmente também com o spinozismo. A visão filosófica para a qual vale o princípio de que o ser é somente ser e o nada somente nada merece o nome de sistemas de identidade. Essa identidade abstrata é a essência do panteísmo' (...). Na verdade, o 'nada' de Aristóteles é, com efeito, um nada privativo que, assim como a privação aristotélica, está na constituição do devir. Portanto, todas as discussões a que a definição hegeliana do D. deu origem entre os hegeliano (e também entre os não hegelianos) parecem hoje completamente ociosas". 56

A esta nova lógica a qual denominou de dialética dos opostos possui os moldes heraclíticos porque, no seu desenvolvimento, compõe a si mesma.

Ela se contrapõe ao princípio da identidade e da contradição tipicamente aristotélico e foi avaliada por Hegel como sendo a mais adequada lei do "ser" que é definido como o devir absoluto.

Segundo a lógica hegeliana, a realidade não é, nem não é; se for, é essencialmente devir, cujo conceito, ao contrário da lógica tradicional que coloca como sendo universal abstrato, é universal, mas concreto, ou seja, o individuo tem uma vinculação com a total realidade se desenvolve dialeticamente.

Este desenvolvimento dialético faz com que o Espírito atinja a completa consciência de si mesmo o que, para alguns, resulta num verdadeiro panlogismo ${ }^{57}$ dinâmico.

Neste incondicional devir da realidade, Hegel aponta as três grandes fases do conhecimento do Espírito: a ideia (fase do em si, a tese, trata-se de um sistema de conceitos puros que descrevem os esquemas do mundo natural e do espiritual, sendo o princípio inteligível da realidade, estudado pela lógica), a natureza (do em si, surge a fase do fora de si, que é a exteriorização da ideia no tempo e espaço, concretizando-se na história, representando a antítese da fase anterior. É objeto de estudo da filosofia da natureza) e o espírito (é a ideia consciente de sua divindade imanente, é o retorno da ideia

\footnotetext{
${ }^{56}$ Dicionário de Filosofia, verbete.

${ }^{57}$ Doutrina que prega a identidade entre o real e o racional.
} 
para si mesma é a terceira fase, a síntese. É a fase do por si, estudada pela filosofia do espírito).

Também o Espírito se apresenta em três momentos dialéticos: o da individualidade empírica (espírito subjetivo), na qual nasce a consciência do mundo, para o da sociedade (espírito objetivo), culminando no terceiro que é a sociedade do Estado (espírito absoluto) chamado por Hegel de "espírito vivente, razão encarnada, deus terreno".

E cada momento se desenvolve na sua dialética própria. Do indivíduo: consciência, autoconsciência e razão. Da sociedade: direito, moralidade e eticidade. Do Estado: arte, religião e filosofia.

A lógica, o pensamento e, portanto, toda a realidade sempre trabalha em trilogia e em dialética (tese - antítese - síntese).

Mas, como já visto, se todo real é racional (e vice-versa), este conflito não é entendido como sendo algo abstrato que possui como características ser imediato e finito, mas é, ao contrário, concreto, ou seja, aquilo que é verdade e objeto infinito.

A incongruência entre tese e antítese é realidade concreta e verdadeira e a síntese é a conciliação desta realidade.

Também no mundo jurídico acontece esta síntese.

$\mathrm{Na}$ filosofia grega, o pensamento clássico se caracterizava pela relativação do indivíduo perante a coletividade a qual lhe dava sua existência e finalidade. É a tese.

Na filosofia medieval ainda não se havia alcançado a síntese, apesar de se ter iniciado o aprendizado para uma autoconsciência e valorização do indivíduo desvinculando-o da antiga autoridade do coletivo sobre ele, o que ocorreu desde o cristianismo até Kant (a antítese).

Mas agora, Hegel, com suas raízes firmadas no Iluminismo, vivendo um momento particular da história burguesa moderna, assinala o indivíduo como sujeito de direito como um dos temas centrais do pensamento jurídico para, depois, culminar na noção de Estado que o apresenta. Não é mais o coletivo que fornece a identidade e a finalidade ao indivíduo. 
No confronto da tese com a antítese, se alcança a sua conciliação: é o indivíduo o eixo que nasce com direito que lhe são inerentes e, neste momento, é o coletivo que passa a necessitar dele para existir e conseguir finalidade. Eis a síntese.

E mesmo esta síntese se desenvolve em três momentos dialéticos, culminando no Estado chamado de Espírito absoluto.

"Hegel - ensina Alysson Leandro Mascaro - sistematiza seu pensamento jurídico (...), dividindo-o em três partes fundamentais: direito abstrato, moralidade e eticidade. Traduzindo-as de outro modo, trata-se do direito da individualidade (primeira parte), do direito como moralidade subjetiva (segunda parte) e do direito como moralidade objetiva (terceira parte). No que tange ao ponto específico da eticidade, Hegel percebe nela um transcurso de vários graus: seus níveis primeiros se encontram na família, depois passando pela sociedade civil, para, enfim, ter por ápice o Estado". ${ }^{58}$

Porém, se deve observar que até mesmo o desenvolvimento que se encaminha para o atingir em plenitude com o Estado, muito embora supere o primeiro e o segundo momentos, necessitou da existência da sua primeira condição do direito abstrato inteiramente vinculada ao indivíduo.

O Estado (apesar de não localizar o seu fundamento no individual, porque é superior a este, assim como da moralidade) não poderá existir independente e anteriormente ao indivíduo, como apontava Aristóteles, mas é necessitado do indivíduo para o seu efetivo desdobramento.

Por indivíduo deve ser entendida a pessoa de vontade subjetiva, abstrata (não é a real, concreta e histórica) e livre porque decide por si mesma, ou seja, o sujeito de direito, que oriundo de um processo histórico.

Este mesmo processo histórico não permite que sujeito de direito fique em repouso, mas exige a passagem da pessoa subjetiva para a pessoa objetiva, pela necessária dialética que governa a realidade em direção ao Espírito absoluto, apresentando como primeira manifestação de exteriorização de sua vontade a capacidade de ser proprietário.

${ }^{58}$ Filosofia do direito, p. 250. 


\section{Diz Hegel:}

“41 - Deve a pessoa dar-se um domínio exterior para a sua liberdade a fim de existir como ideia. Porque nesta primeira determinação, ainda completamente abstrata, a pessoa é vontade infinita em si e para si, tal coisa distinta dela, que pode constituir o domínio da sua liberdade, determina-se o que é imediatamente diferente e separável.

42 - O que é imediatamente diferente do espírito livre, e considerado este como em si, é a extrinsecidade em geral: uma coisa, qualquer coisa de não livre, sem personalidade e sem direito.

Nota - A coisa, como a objetividade, tem duas significações opostas: por um lado, quando se diz ' é uma mesma coisa, trata-se da coisa e não da pessoa', isso significa algo substancial; por outro lado, porém, a coisa aparece em relação à pessoa (não no sentido de sujeito particular) como o contrário do que é substancial, como aquilo que por definição é apenas extrinsecidade. O que é extrínseco para o espírito livre (que se deve distinguir da simples consciência), o é de uma maneira absoluta, em si e para si, tal como a definição conceitual da natureza é a de ser a extrinsecidade em si mesma."59

É a necessidade da Ideia de se concretizar historicamente, onde dominar as coisas, ter a sua propriedade, é o primeiro passo de dar-se a conhecer do sujeito de direito.

Neste momento, a coisa não é mais definida como se apresentava em Kant. A coisa é, agora, uma verdadeira marcha na qual a subjetividade primitiva se lança "para fora de si" em elementos externos à consciência, estabelecendo-se como realidade externa.

Por isso, a liberdade a qual o sujeito de direito detém não é para si, conquanto ainda abstrato, mas deve ser concebida em relação e como movimentação necessária para o efetivo desenvolvimento do Espírito.

O Estado surge após a essencial realidade do sujeito de direito que se objetiva.

${ }^{59}$ Princípios da filosofia do direito, p. 44. 
Apesar de Hegel apontar o Estado como sendo deus terreno, fundamentado na potência da razão que se efetiva como vontade (também individual, dele), é possível se identificar neste ponto a miséria do Estado hegeliano.

"O Estado, pensado como elemento superior da dialética da história, é uma entidade autorreferente, na medida em que se alicerça na sua mecânica jurídica pública, nos seus costumes e nas suas relações políticas concretas - é juridicamente distinto dos indivíduos que lhe são subordinados, ou seja, é soberano. Mas é também, ao mesmo tempo, o espaço de consolidação da cidadania dos indivíduos, que encontram no Estado, submetendo-se a ele, sua razão de ser coletiva. Ao subordinar os indivíduos, integra-os e os dota de objetividade, verdade e moralidade. (...) É justamente o Estado que garante o sujeito como cidadão."60

“O Estado, para Hegel, é uma individualidade, animando o próprio povo. (...) O Estado é uma individualidade com seus próprios interesses e necessidades históricas."61

Porém, é um erro entender que o Estado de Hegel se reduz, como afirmam os contratualistas, num acordo de vontades decorrente de uma convenção e aceitação mútua de cidadãos que são naturalmente isolados e que passam, por necessidade ou opção, a compartilhar de uma mesma sociedade.

Partindo inicialmente dos sujeitos de direito, situação alcançada na movimentação da história, a realidade do Estado não dependerá mais desses, porque o Estado é em si (abstrato, imediato, que não traz referência com outro) e para si (contraposto ao em si, designa o real racional, que se desenvolveu por meio da reflexão e da consciência).

Com a dialética em progresso, não há mais um sujeito de direito subjetivo; há a universalização do sujeito de direito na propriedade, ou melhor, de sujeitos de direitos que se relacionam como senhores de coisa que é a exteriorização da pessoa: o ter mostra o ser.

\footnotetext{
${ }^{60}$ Alysson Leandro Mascaro, Filosofia do direito, p. 253.

${ }^{61}$ Ibidem, p. 261.
} 
Outro confronto para com Kant. Enquanto neste o servo jamais será livre porque é coisa assim considerada para o seu senhor, em Hegel, o servo mantém-se livre, se a condição de servo foi livremente buscada por este último. Se é servo, é porque assim quis ser e continua a ser a sua livre vontade que se realiza.

A coisificação não atinge a vontade do sujeito de direito em si, mas somente sua exteriorização, como o operário, que é sujeito de direito de vontade livre, que vende sua força de trabalho (coisa) em determinada jornada do seu dia (coisa); ele não vende a sua pessoa (porque não pode ser coisa, vez que é sujeito de direito): é "servo" somente porque assim quis, como também pelo tempo que aceitou ser. Pode se coisificar porque é livre. É a realização da dialética do senhor e do escravo exposta na Fenomenologia do Espírito.

O Espírito se realiza de forma plena na história ao alcançar a situação de sujeito de direito universal e a perfeita autoconsciência, e o Estado é a sua realidade objetiva, o racional em si e para si.

A história não deve ser entendida como um encadeamento aleatório de acontecimentos, mas um suceder imanentemente dialético por meio da qual o Espírito vem a ser em sua autoconsciência, atingindo a si mesmo.

A protagonista na história é o Espírito absoluto.

Não há mais o que acrescer: o Espírito absoluto se autocompreende como sendo a realidade total e esta é a sua manifestação.

Estruturado sobre o individualismo de Kant, concretiza-se o Estado burguês, amparado pela filosofia de Hegel, e não é mais necessário o imprescindível caminhar dialético. Chegou-se ao "ápice”. Não cabe mais discutir, mas tão apenas cumprir as determinações do "deus encarnado".

Esse é o tempo que Hegel vive e esta é a filosofia que esse tempo necessitava.

Abre-se o caminho para o enraizamento do pensamento juspositivista (cujas raízes se encontram na pregação de Paulo e Agostinho), filosofia de aceitação 
comum a maioria dos juristas até pouco tempo recente ${ }^{62}$, tendo na teoria geral do direito Hans Kelsen seu melhor representante.

Porém, um outro irá desafiar e criticar o pensamento e o Estado burgueses.

\section{c) O sujeito em Marx (autor e ator da história).}

O marxismo é uma filosofia crítica ${ }^{63}$ e percorre uma um caminho totalmente diverso quanto ao sujeito de direito e sua subjetividade.

Partindo da via histórica de Hegel que muito o influencia desde o início de sua formação, de forma revolucionária, Marx coliga o desenvolvimento do pensamento jurídico com o desenvolvimento do capitalismo, identificando-o como sendo uma das estruturas para a reprodução do sistema, além de apontar as suas contradições.

“A compreensão do marxismo há de identificar, de forma profunda, os nexos que vinculam o fenômeno jurídico moderno ao capitalismo. São as relações capitalistas que dão especificidade ao direito tal qual este apresenta nas sociedades contemporâneas."

Karl Marx nasce em 1818 na cidade de Trier, sendo o segundo dos nove filhos de família judaica de classe média. Estuda direito, inicialmente em Bonn e depois, transferido, em Berlim. Discente de uma universidade onde Hegel fora professor e reitor, é membro do movimento denominado Jovens Hegelianos.

Embora seja em forma de censura, uma de suas obras é justamente sobre o antecessor: Crítica do Direito Público de Hegel (1843) onde rejeita uma explicação racional da realidade.

\footnotetext{
${ }^{62}$ Na segunda metade do século XX, se introduz na discussão jurídica as questões da linguagem, estudando o direito como se fosse uma espécie de lógica normativa.

${ }^{63}$ Alysson Leandro Mascaro, Filosofia do direito, p. 443.

${ }^{64}$ Ibidem, Filosofia do direito, p. 443.
} 
Obtém o título de doutor com um estudo filosófico sobre os présocráticos Demócrito e Epicuro, ainda sob inspiração de Hegel.

Pretende ser professor, mas, diante de vários empecilhos, desiste da carreira e passa a trabalhar em redação de jornais, o que lhe impõe estar em contato diário com problemas da vida concreta sobre política e economia enfrentados pelo povo e com o movimento operário, especialmente a partir de 1840. Até então redige textos de caráter mais liberal.

O início comunista pode ser colocado quando Marx se muda para Paris onde passa a viver na casa de amigo para, depois, novamente se mudar junto com toda a família para Londres onde passa inclusive por sérias dificuldades econômicas e de saúde.

A partir de 1844, a amizade com Friedrich Engels, além de salvá-lo da falência total, o estimula a abdicar definitivamente do seu vínculo com a esquerda hegeliana e contribuirá, e muito, na elaboração de seus escritos mais famosos: O Manifesto Comunista e $O$ Capital.

A crítica de Marx se inicia com a noção de história em Hegel a qual atribui ser muito mais fruto de um misticismo racional ou de uma ideologia, pois a submete ao autoconhecimento do Espírito, assim como fazem os crentes com o divino, do que de uma verdadeira compreensão da realidade.

Em oposição, Marx atua na opção de que não só a história, mas todo o pensamento filosófico deva ser corrigido e estabelecido no aquém de uma visão concreta.

Esta opção demonstra que a história não segue um raciocínio, uma lógica, mas é contraditória e incapaz de ser sistematizada. O real não é o racional, mas é a realidade da práxis humana.

Quem atua na história é o homem. Ele é o sujeito real que cria a realidade, inclusive a divina.

E o homem não se resume a sua razão ou a sua capacidade cognoscente. Ele é a sua realidade material concreta de vida, não só individual, mas essencialmente social, o que foi denominada de práxis. 
"Com esta palavra (que é a transcrição da palavra grega que significa ação) afirma Abbagnano ao explicar a palavra "práxis" - a terminologia marxista designa o conjunto de relações de produção e trabalho, que constituem a estrutura social, e a ação transformadora que a revolução deve exercer sobre tais relações. Marx dizia que é preciso explicar a formação das ideias a partir da 'praxis material', e que, por conseguinte, formas e produtos da consciência só podem ser eliminados por meio da 'inversão prática das relações sociais existentes', e não por meio da crítica intelectual (...)". 65

Portanto, não se deve se deter no campo do pensamento puro de Kant ou do ideal de Hegel, mas trabalhar para a transformação da realidade prática que indica em toda parte que o homem sofreu a perda das autênticas possibilidades de existência o que irá denominar de alienação.

"Segundo Marx, Hegel cometeu o erro de confundir objetivação, que é o processo pelo qual o homem se coisifica, isto é, exprime-se ou exterioriza-se na natureza através do trabalho, com a A., que é o processo pelo qual o homem se torna alheio a si, a ponto de não se reconhecer. Enquanto a objetivação não é um mal ou uma condenação, por ser o único caminho pelo qual o homem pode realizar a sua unidade com a natureza, a A. é o dano ou a condenação maior da sociedade capitalista." 66

Esta sociedade capitalista, que se movimenta com o seu idealismo de base kantiana e hegeliana e atrelada aos interesses burgueses, promove a alienação do homem por meio da expropriação do seu trabalho (transformado em coisa) que não serve mais para humanizar a natureza, mas tão apenas para a sua sobrevivência e de sua família, situação na qual o operário destrói seu espírito e arrasa seu corpo.

Assim alienado, só trabalhando e sem transformação alguma, o homem é comparado com a aranha que executa operações semelhantes às do tecelão e a abelha que supera vários arquitetos na construção da sua colméia.

O trabalhador, como um todo, se torna coisa de mercado, porque está trabalhando sem sentido, em algo que lhe é externo. A alienação alcança todos outros campos.

${ }^{65}$ Dicionário de filosofia, verbete.

${ }^{66}$ Ibidem, verbete. 
O operário já não trabalha mais espontaneamente para humanizar a natureza, mas é forçado para gerar a cada momento maior riqueza de coisas, enquanto mais pobre fica (mesmo naquelas coisas que ele mesmo produz), e de si mesmo (pois passa a não mais se sentir humano, mas concorrente com os animais que tão somente querem comer, procriar e se abrigar).

Instigado pelo sistema produtivo capitalista, o alienado afasta-se de si mesmo.

Parafraseando, Marx almeja uma sociedade não alienante onde o trabalho seja um processo participativo entre o homem e a natureza, no qual o ser humano com sua própria ação estimule, regule e controle seu intercâmbio material com a natureza.

Desta forma, atua sobre a natureza externa, modificando-a, ao mesmo tempo modifica a sua natureza e desenvolve potencialidades nela adormecidas.

Será preciso, portanto, uma revolução, não ideal e abstrata, mas real e concreta; não de consciência apenas, mas do ser social, obtida por meio da luta de classes no intuito de acabar com a propriedade privada, fonte do capitalismo que se alimenta do trabalho alienado do trabalhador, visto como mera coisa nas mãos do proprietário.

Já não existe mais aquele que poderia ser sujeito de direito e coisa ao mesmo tempo ou em momentos ou situações alternadas.

Todos são sujeitos de direitos, pois tornaram-se cidadãos de um estado, contudo, temos pessoas de um lado e coisas do outro.

Para a que a revolução aconteça, não basta que o estado, tal como se encontra, progrida. Se assim, for, embora aconteça aqui ou ali relances de socialização de direitos, o estado continuará um estado solicitado e amparado pelo capitalismo.

Faz-se necessária uma verdadeira mudança de rota: re+evolução.

Esta mudança é proposta por Marx com o suplantar do individualismo, se fixando no social.

A pessoa, até então, entendida na sua dimensão individual quer por uma racionalidade, quer por um destino divino ou quer por uma necessidade, deve se sociabilizar. 
Marx suplantando o idealismo e o humanismo do passado e propõe que se entenda toda a realidade a partir da dinâmica da vida social concreta.

"Superando o individualismo presente no kantismo e a sagração do Estado por parte do hegelianismo, Marx já aponta para um eixo ainda mais profundo da lógica social, que será depois desenvolvido em suas obras. A filosofia se pensa na radicalidade da vida social. O Estado não é o universal; as classes manifestam uma verdade social ainda maior: (...). ${ }^{67}$

“O subjetivismo, próprio do pensamento moderno, estará definitivamente sepultado pela crítica marxista. Não se trata mais de conhecer o mundo com base no homem em si, ou em sua essência, ou em sua natureza, ou em seus atributos fundamentais. Na verdade, o homem somente o é enquanto se perfaz nas próprias relações sociais, de trabalho. (...)

"Rompendo, pois, com as tradições tanto materialistas quanto idealistas, que buscavam ou uma natureza e necessidades humanas ou essências abstratas, Marx inscreverá o homem em seu trabalho, em sua relação objetiva com a natureza (...). Consegue, pois, definitivamente, ultrapassar a barreira filosófica da tradição moderna que limitava o homem a sua individualidade, a sua subjetividade. A compreensão humana é a partir da práxis, (...)"68

Em Marx, o homem é sociabilidade, encontrando na aptidão social a sua mais verdadeira natureza.

Aí está o ponto de diversidade do seu materialismo histórico dialético (a dialética é uma herança hegeliana transformada em método de análise da realidade social) daqueles outros que o antecederam.

A "ciência da história" de que trata o materialismo histórico dialético mostra que a concepção filosófica que governa a vida social depende e é condicionada pela estrutura sócio-econômica que a justifica. A mudança radical da direção social deve começar a partir da transformação desta estrutura.

\footnotetext{
${ }^{67}$ Alysson Leandro Mascaro, Filosofia do direito, p. 269.

${ }^{68}$ Ibidem, p. 273.
} 
Tal estrutura é mantida por pilares dos quais um deles, o estado, se apresenta como essencial. Ele é a classe social burguesa e o capitalismo organizado em sua política.

O estado, como se apresenta historicamente, não surge para defender o bem comum ou a real igualdade entre os seus cidadãos, como anuncia e faz crer. Ele tem a missão de estabelecer e organizar os trabalhadores que, julgando-se livres porque estão protegidos em sua liberdade por um mesmo estado, são capazes de negociar.

Esta é a função do estado burguês para o capitalista: permitir e amparar a exploração da força de trabalho dos operários que devem se julgar livres para voluntariamente negociar a venda de seu tempo e energia.

E para esta missão, nada melhor do que criar da ilusão de que os trabalhadores são verdadeiros sujeitos de direito dotados de liberdade e de vontade própria, formal e juridicamente iguais perante a lei, inclusive com relação aos detentores do poder de produção.

$\mathrm{Na}$ realidade, o estado legitima e organiza a exploração do mercado dos sujeitos de direitos nos moldes capitalistas utilizando-se do direito como seu instrumento capital.

A criação do sujeito de direito foi um fenômeno de exigência do sistema capitalista burguês diante da necessidade da circulação não só de bens, mas também da força de trabalho no mercado.

Mas somente pode negociar sua capacidade de trabalho no mercado com quem quiser aquele que é dotado de capacidade jurídica, considerado sujeito de direito, dito possuidor de liberdade e de vontade própria.

Portanto, o estado não é indiferente em sua atividade e a justiça do seu direito não é cega (se fosse, não precisaria de uma venda para tapar seus olhos).

"Marx - afirma Alysson Leandro Mascaro na sua obra Filosofia do Direito altera a compreensão do direito; não mais aquela da filosofia do direito moderna, na qual o fenômeno jurídico era pensado a partir de uma ideia ou um conceito de justo. $\mathrm{O}$ direito não é um produto histórico do melhor aclaramento da consciência do jurista, nem tampouco da melhor elaboração dos conceitos. 
$\mathrm{Na}$ verdade, o direito se constitui pela necessidade histórica de as relações produtivas capitalistas estabelecerem determinadas instâncias que possibilitem a própria reprodução do sistema". 69

Com a filosofia marxista, fica evidente que o direito fora transformado numa espécie de paladino que resguarda o mercantil.

E a exigência capitalista não se restringiu ao surgimento do sujeito do direito, mas atingiu a universalização desta categoria.

Em Marx, quando se refere ao processo de trocas, a famosa passagem contida na obra $O$ Capital (Livro I, início do capítulo II):

"As mercadorias não podem por si mesmas ir ao mercado e se trocar. Devemos, portanto, voltar a vista para seus guardiões, os possuidores de mercadorias. As mercadorias são coisas e, consequentemente, não opõem resistência ao homem. Se elas não se submetem a ele de boa vontade, ele pode usar de violência, em outras palavras, tomá-las. Para que essas coisas se refiram umas às outras como mercadorias, é necessário que os seus guardiões se relacionem entre si como pessoas, cuja vontade reside nessas coisas, de tal modo que um, somente de acordo com a vontade do outro, portanto cada um apenas mediante um ato de vontade comum a ambos, se aproprie da mercadoria alheia enquanto aliena a própria. Eles devem, portanto, reconhecerse reciprocamente como proprietários privados. Essa relação jurídica, cuja forma é o contrato, desenvolvida legalmente ou não, é uma relação de vontade, em que se reflete a relação econômica. O conteúdo dessa relação jurídica ou de vontade é dado por meio da relação econômica mesma. As pessoas aqui só existem, reciprocamente, como representantes de mercadorias e, por isso, como possuidores de mercadorias. Veremos no curso do desenvolvimento, em geral, que os personagens econômicos encarnados pelas pessoas nada mais são que as personificações das relações econômicas, como portadores das quais elas se definem". 70

${ }^{69}$ p. 293.

${ }^{70}$ O capital, Edipro, p. 209-210. 
Vê-se que o sistema capitalista não se interessa somente pela mercadoria isolada, nem só pelo guardião da mercadoria ou proprietário como realidades subjetivas.

Ele se interessa, numa visão mais larga e universal, também pelos guardiões e proprietários (sujeitos de direito para o mundo jurídico) que, ligados de modo capital a mercadoria que possui, for apto e capacitado de se relacionar com os outros guardiões ou proprietários no relacionamento mercantil de trocas, fundamento do ius abutendi.

Portanto, não se trata de um subjetivismo jurídico que resta protegido pelo direito capitalista que dirige as trocas de mercadorias, mas de uma universalidade a partir do subjetivismo jurídico, o qual desaparece (em favor do universal) quando mercantiliza suas propriedades.

O importante não é o proprietário, nem a mercadoria, mas a transformação em objeto de comércio de tudo aquilo que possível for, inclusive do próprio sujeito de direito.

Marx aponta na passagem, portanto, que todos os homens serão reconhecidos por serem guardiões de mercadorias, reconhecimento este que é sustentado pelo ordenamento jurídico que lhe determina e orienta quando a sua capacidade para a prática de atos jurídicos.

Apesar de a forma jurídica denominar a todos os homens genericamente de sujeitos de direito, que se observe que o direito capitalista, fruto desta mesma sociedade, o que promove e regula é o encontro e o negociar de proprietários de mercadorias.

Se o sujeito de direito possui valor para o direito, é somente enquanto proprietário apto para comercializar mercadorias (coisas ou força de trabalho). E é assim que eles se reconhecem: no mercado.

Contudo, para que possam negociar, os sujeitos de direito devem obrigatoriamente ser livres e iguais.

A liberdade se realiza no desejo voluntário de colocar no mercado determinada coisa sua ou, se nada mais tiver, de sua capacidade de trabalho e de adquirir o que quiser de quem quiser que voluntariamente também colocou a sua mercadoria à 
disposição de aquisição de outro. Segundo o sistema capitalista, cada um comercializa o que quer, com quem quer, quando quer.

A igualdade, por sua vez, se realiza na proteção jurídica necessária que determina que não exista diferenças entre os sujeitos, vez que impossível negociar com diferentes, ou seja, incapazes aos atos do comércio. Cada sujeito de direito é visto igualmente como um negociante e o reconhecer-se igual ao outro favorece e impele o comércio.

Liberdade de mercado e igualdade no mercado são qualidades essenciais e necessárias do sujeito de direito no sistema capitalista, para a sobrevivência da movimentação de mercado.

Mas essas qualidades essenciais não são postas para a realização do sujeito de direito.

Elas têm objetivo diverso que não se encaixa no sujeito de direito. Seu alvo é a circulação das mercadorias. É uma liberdade e uma igualdade não para o sujeito, mas para o mercado.

$\mathrm{O}$ direito tem a função de esconder esta realidade fazendo com que o sujeito de direito se considere ele o agraciado e merecedor. O não perceber desta invocação histórica é indício da alienação.

E o sujeito de direito sempre será proprietário de ao menos uma mercadoria para o comércio: a sua força de trabalho que, ao ser transformado em mercadoria, será colocada no comércio por determinado equivalente em dinheiro (salário).

Ele é considerado proprietário não tanto porque a mercadoria seja dele, mas porque pode dispor dela como quiser. De nada vale ser proprietário de algo que não pode comercializar.

Neste ponto está o a prerrogativa maior do sujeito de direito: manifestar a sua vontade subjetiva colocando sua mercadoria no processo de compra e venda.

O sujeito de direito alcançado como uma forma de abstração universal do guardião da mercadoria encontra na circulação mercatória a sua razão de existir. 
Se as mercadorias não necessitassem circular no mercado, não haveria razão para ele existir. Como dito antes: não importa quem comercializa o que for; o que importa é que se comercialize.

O direito deve cuidar do comércio.

Neste campo, não há um subjetivismo; existe uma universalização do sujeito de direito subjetivo dominado e dirigido pelas rédeas do capital.

Marx expõe às claras que a condição de sujeito de direito não é algo de natural ao homem.

Ele é um produto da história, fruto de um processo histórico social.

O desenvolvimento da personalidade jurídica do sujeito foi exigência de desdobramentos do crescimento capitalista e seu exigente comércio.

Após a exposição do pensamento dos autores acima indicados sobre a figura do sujeito do direito, verifica-se a correção do dito de Habermas:

"Do ponto de vista histórico, os direitos subjetivos privados, que foram talhados para a busca estratégica de interesses privados e que configuram espaços legítimos para as liberdades de ação individuais, constituem o núcleo do direito moderno". ${ }^{71}$

Por conclusão desta primeira parte, necessária a citação de dois textos de muito proveito.

O primeiro texto de autoria de Aloysio Ferraz Pereira que dá uma síntese do todo apresentado:

“A serviço do indivíduo.

Primeiramente acreditar-se-ia que uma filosofia individualista se contentaria em ignorar o direito. O Evangelho cala-se quanto ao direito. Quanto às doutrinas helenísticas, estóicas ou epicuristas, por muito tempo elas não foram tratadas como filosofias do direito; eram exploradas no seu próprio terreno, o

${ }^{71}$ Direito e democracia, p. 47. 
da moral, para dirigir a conduta pessoal do sábio. E não se lhes pedia em Roma que fornecessem os princípios do jus civile.

Não era menor a discordância entre a primeira grande eclosão do nominalismo, no mundo religioso franciscano, e a arte dos juristas. Os nominalistas em princípio se interessam pelos indivíduos, enquanto seres únicos, no que cada homem apresenta de irredutível aos outros - como é tal moça para seu noivo, Deus para o místico franciscano.

Estes filósofos dos tempos modernos, atormentados, obcecados pelo seu $e u$, submersos no coração da subjetividade, não irão calar-se sobre o direito? É o contrário que se verifica e podemos compreender por quê. Toda filosofia é tentacular. Quando se impõe certa linguagem, certa maneira de ver o mundo, de separá-lo em elementos e raciocinar sobre esses elementos, o espírito de sistema obriga a ver todo o universo sob esta visão. Seria preciso que a filosofia individualista moderna explicasse o direito, que desse sua definição de direito. Os juristas contemporâneos são os primeiros interessados em conhecer esta definição, porque sua teoria jurídica dela procede na maior parte...".72

O segundo texto, a conclusão que apresenta Michel Villey em uma das suas obras:

"Estas reflexiones sobre la outra vía de la subjetividade han aberto una perspectiva que tiene al menos dos implicación es fundamentales. La primera es la que hemos subrayado desde el principio, a saber, que la teoría moderna de la subjetividade no se debeconcebir como uma teoria que procede de forma unívoca de las posiciones de Descartes. Em efecto, la outra vía de la subjetividade se desarolla, a través de sus diversas figuras, e nun plano distinto (locual no impede las coincidencias, ni las oposiciones). La segunda es que las teorías del sujeto y de la subjetividade que hemos examinado, lejos de cuestionar la existencia de valores y de normas universales, la fundamentan. Dicho de outro modo, la figura del sujeto que se dibuja en la corriente intelectual del derecho natural moderno no es la de um sujeto replegado sobre sí mismo sino de um sujeto aberto a lo universal. Por tanto, la outra vía de la

${ }^{72}$ Textos de filosofia geral e de filosofia do direito, p. 109. 
subjetividade debe ser capaz de proporcionar los instrumentos conceptuales necesarios para afrontar y superar el subjetivismo y el relativismo, generalmente considerados como derivación es directas de la figura del sujeto moderno."73

Aplicando-se para a filosofia heideggeriana, não há que se falar do sujeito de direito clássico da filosofia jurídica, mas sim do Dasein (ser-no-mundo-para-amorte) entendido como sendo o homem aberto não ao universal, mas ao mundo. Tomemos o pensamento de Heidegger. Por quê? Porque nunca se poderá ter uma conclusão jurídica que não seja apropriada ao ser natural.

${ }^{73}$ La outra vía de la subjetividade, p. 114-115. 


\section{Capítulo II - Construção analítica de Heidegger}

Antes, necessário compreender o termo "desconstrução", visto que a filosofia de Heidegger está muito ligada à noção de desconstrução, termo trazido para a filosofia por Derrida e que comporta variada coletânea de significados e noções.

O que é desconstruir?

Para muitos, esta palavra sempre vem acompanhada pelo área da engenharia civil no setor de construção, mas na verdade desconstruir é mais abrangente a diversos temas tanto na área do conhecimento exato, como também em outros (literatura, por exemplo).

$\mathrm{Na}$ teoria da engenharia, descontruir está ligado ao ato de desfazer, desmontar ou de desagregar.

Há uma diferença entre desconstruir e demolir, sendo que a desconstrução pode ser uma etapa de qualquer processo, como por exemplo desmontar um aparelho.

Já demolir é destruir, arruinar, acabar com tudo aquilo construído de forma a perder tudo.

É possível saber como foi construído (ou saber construir) desconstruindo.

$\mathrm{Na}$ engenharia, esse processo é chamado de engenharia reversa que tem por objetivo o estudo de algo que já foi criado, não sendo uma cópia. A engenharia reversa também pode ajudar a entender o funcionamento de algo, para desenvolver o objeto de estudo, ou mesmo produzir algo completamente novo, a partir de dados coletados.

Nascido em 1889 na pequena cidade de Messkirch, do estado de BadenWürttemberg, sul da Alemanha, Martin Heidegger ainda jovem ingressa no seminário jesuita, não tanto para ser padre, mas para aproveitar dos estudos que lá lhe era oferecidos.

Depois de alguns anos, deixa o seminário e estuda teologia e filosofia na Universidade de Freiburg - distante um pouco mais de uma centena de quilômetros da sua cidade. Heidegger foi aluno e secretário particular de Edmund Husserl, o fundador 
da fenomenologia, a quem dedicou a primeira edição da sua obra principal (dedicatória retirada posteriormente).

Após ser professor na Universidade de Marburgo, a partir de 1929, sucede Husserl na cátedra de filosofia na Universidade de Freiburg apresentando como tema inaugural a famosa aula "O que é a metafísica?".

Em 1927 publica sua obra maior: Ser e Tempo.

O ano de 1933 é um período até hoje controvertido porque assume a reitoria da Universidade e proclama o discurso “A auto-afirmação da universidade alemã".

Sobre este período cabe esclarecer: Hitler, que não foi aceito pela Academia de Belas Artes de Viena em 1907 onde pretendia fazer estudos artísticos, foi nomeado Chanceler do Reich em 30 de janeiro de 1933 pelo presidente Paul von Hindenburg, apoiado por 230 deputados nazistas eleitos em 1932 do Partido Operário Alemão Nacional Socialista.

Em janeiro de 1933, Heidegger diria junto com todo o povo alemão (e com a concordância e apoio da burguesia industrial e financeira) que Hitler era a única saída para o aumento do desemprego, da inflação e da humilhação da Alemanha pelos vencedores da Primeira Guerra Mundial.

Sobre este período, Martin Heidegger concedeu uma famosa entrevista para a revista semanal alemã Der Spiegel em 23 de Setembro de 1966 (publicação n. $\left.{ }^{0} 23 / 19761\right)$ :

"DER SPIEGEL: Foi por isso que assentiu definitivamente? Como se desenvolveu a sua relação com os nacional-socialistas?

M.H.: Dois dias depois da minha tomada de posse, apareceu na Reitoria o dirigente dos estudantes (Studentenführer) com dois acompanhantes, exigindo de novo a colocação do 'cartaz dos judeus'. Recusei. Os três estudantes afastaram-se com a advertência de que avisariam a Direcção de Estudantes do Reich (Reichsstudentenführung) do indeferimento. Alguns dias depois recebi uma chamada telefónica dos Serviços Universitários das SA, pertencentes à Direcção Suprema das SA, da parte do Dr. Baumann, chefe de grupo das SA. Exigia a colocação do cartaz, tal como se fizera já noutras universidades. Em 
caso de recusa, deveria contar com a demissão, senão mesmo com o encerramento da Universidade. Procurei ganhar o apoio do Ministro da Cultura de Baden para o meu indeferimento. Ele explicou-me que não podia fazer nada contra as SA. Mesmo assim, não levantei a proibição." ${ }^{, 74}$

Desta forma, Heidegger explica seu comportamento com a história da Alemanha, mas não com a política da Alemanha. Afirma que:

1. No inverno de 1932-33 passou a maior parte do tempo em sua cabana na região de florestas;

2. Que em 1933 (mais ou menos no final de abril) assume a Reitoria da Universidade de Freiburg, negando, como se viu acima, estigmatizar os estudantes judeus com a marca imposta pelos estudantes nazistas, como também continuou permitindo o comentário de autores judeus nas aulas e seus livros não foram retirados da biblioteca que cuidava;

3. Que se demitiu em fevereiro de 1934, 10 meses após ter ocupado o cargo e que a imprensa fez silencia sobre a sua demissão;

4. Que se recusou a assistir à cerimônia oficial de transmissão do cargo a seu sucessor, que era um jurista, que o jornal do partido Der Alamano anunciou a nomeação um o título: "O primeiro reitor nacional-socialista da Universidade"75, deixando claro que o próprio nazismo, por sua imprensa, quis apagar Heidegger da história da Universidade.

Com a recusa, é forçado a renunciar e deixa a Reitoria, dedicando-se a docência, palestras e seus escritos.

Em janeiro de 1934, já estaria instalada a ditadura nacional-socialista.

Em agosto de 1934, com a morte de Hindenburg, Hitler tornou-se presidente do Reich.

\footnotetext{
74 In http://www.lusosofia.net/textos/heideggger_ja_so_um_deus_nos_pode_ainda_salvar_der_spiegel.pdf, acesso em 12 de janeiro de 2014.

${ }^{75}$ Em vários comentários sobre o fato, erroneamente aplicam o título do jornal ao próprio Heidegger, mas como se observa na entrevista o anúncio foi dirigido ao sucessor de Heidegger na Reitoria.
} 
A partir de 1935, nenhuma palavra ou obra sua enalteceria Hitler, como se pode verificar no restante do interrogatório realizado pela Revista Der Spigel.

Morre aos 86 anos, em 26/05/1976, na sua cidade natal onde vivia por mais de 35 anos em recolhimento voluntário, depois de ser proibido de exercer atividades docentes pelo governo alemão. Pelo que se sabe, morreu em decorrência de uma infecção, deixando a viúva Elfriede e dois filhos.

A filosofia de Heidegger é ao mesmo tempo renovadora e intrigante ao se propor uma reconstrução da ontologia na recuperação do sentido do ser.

Logo no início da sua formação, lhe foi marcante a fenomenologia apreendida com Husserl que provocaria a grande virada linguística de Heidegger em busca do ser e da sua morada.

A maior influência de Husserl em Heidegger foi, talvez, a noção do ser projetado para fora de si, o que irá chamar de consciência do mundo que se dá porque se vive fora de si.

Juliana Morais Bicudo apresenta em sua tese a razão da influência:

"Husserl rompe com o conceito de fenômeno proposto por Kant. Para ele, fenômeno se dá no ato de 'ter consciência de algo', compondo-se da noesis e do noema. A noesis se refere ao elemento intencional da consciência (ato de dirigir-se ao ente); (...) O noema é o objeto tal como referido à consciência;",76.

O próprio Heidegger explica a expressão grega fenômeno é $\phi \alpha \imath v o \mu \varepsilon v o v^{77}$ no $§ 7 .^{0}$ de Ser e Tempo:

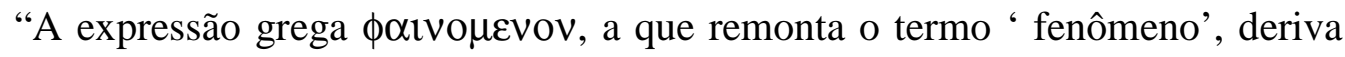
do verbo $\phi \alpha \imath v \varepsilon \sigma \theta \alpha \iota$. $\phi \alpha \imath v \varepsilon \sigma \theta \alpha l$ significa: mostrar-se e, por isso, $\phi \alpha \imath v o \mu \varepsilon v o v d i z$ o que se mostra, o que se revela. Já em si mesmo, porém, $\phi \alpha \imath \varpi \varepsilon \sigma \theta \alpha \imath$ é a forma média de $\varphi \alpha \imath \varpi \omega$ - trazer para a luz do dia, pôr no claro.

\footnotetext{
${ }^{76}$ A investigação fenomenológica da liberdade em martin heidegger, p. 19.

${ }^{77}$ Os termos em língua grega foram retirados de Ser e Tempo.
} 
(...) Deve-se manter, portanto, como significado da expressão 'fenômeno' o que se revela, o que se mostra em si mesmo."78

O fenômeno é, portanto, anunciar sem mostrar toda manifestação do ente, o que proporciona, no direito, a possibilidade de uma via investigativa de busca hermenêutica.

Ou seja, ele propõe um modo de pensar novo, porque a racionalidade de herança iluminista até então utilizada na percepção do ente não serve mais.

Quando o iluminismo desenvolveu uma teoria do sujeito, a racionalidade era a tábua dos valores: é esta subjetividade moderna, do egoísmo do homem moderno, da alienação deste sujeito que se critica, no poço da sua própria subjetividade.

Desconhece a sua própria vivencia social, desta imensa fenda que separa o sujeito, que separa vivendo como uma célula isolada, uma mônada.

O Abismo da subjetividade!

A colocação de Heidegger está no sentido de que não é o sujeito que percebe o ente, mas é este que se deixa revelar.

Aí desponta a reversão que Heidegger empreendeu contra a ontologia clássica.

É como se Heidegger dissesse que não vale a pena mais discutir nos termos da ontologia clássica, devendo se voltar, então, para a ontologia fundamental que tem por tarefa apreender o ser dos entes e explicar o próprio ser em geral.

A experiência do fenômeno para Heidegger possui um caráter objetivo ou impessoal, ou seja, a experiência é tida como possibilidade de repetir as situações.

Diz-se impessoal porque não depende da participação de quem fala, na ou sobre a situação. Este significado é comum a todas as correntes do empirismo.

Assim, para Heidegger, o fenômeno se revolve não como objeto, mas como método de investigação das manifestações ${ }^{79}$ do ente, um método como que imposto pelos entes mesmos.

${ }^{78}$ Vozes, p. 58. 
"O modo de tratar esta questão [da filosofia] é fenomenológica. (...) A expressão ' fenomenologia' diz, antes de tudo, um conceito de método."80

Em palavras simples: a percepção do fenômeno exige um aprendizado para se chegar ao ente, porque não é o sujeito que retira do ente o que quer, mas é o ente que apresenta o que quer.

E se deve aprender que fenômeno é busca e encontro.

"O fenômeno, o mostrar-se em si mesmo, significa um modo privilegiado de encontro". 81

Heidegger clama contra este enorme distanciamento não só do fenômeno, mas do próprio ser dos entes que foi construído dentro da filosofia desde as colocações de Platão que são posteriormente desenvolvidas pelos iluministas para a geração e sustento do sistema capitalista.

Ir ao encontro do fenômeno por meio da fenomenologia é investir numa via investigativa, abrir trilhas na linguagem heideggeriana, que não se tem a certeza de onde vai dar: abre-se o caminho sem pré-conceber o seu destino.

"Fenomenologia, diz, então (...) deixar e fazer por si mesmo aquilo que se mostra, tal como se mostra a partir de si mesmo. É este o sentido formal da pesquisa que traz o nome de fenomenologia. Com isso, porém, não se faz outra coisa do que exprimir a máxima formulada anteriormente - 'para as coisas elas mesmas!",82

E esta nova via trazida pela fenomenologia dos fenômenos percorre a ontologia do ser dos entes de forma totalmente renovada a que ficou conhecida por ontologia fundamental, caminho percorrido a partir do que aprendeu com Husserl.

"Em seu conteúdo, a fenomenologia é a ciência do ser dos entes - é ontologia. Ao se esclarecer as tarefas de uma ontologia, surgiu a necessidade de uma

\footnotetext{
79 A manifestação não é fenômeno porque não mostra claramente o ente. Em um dos seus sentidos, a manifestação age para o sujeito que se põe a conhecê-lo como o arauto que apregoa e aclama quem já está presente no local, mas ainda continua velado sem se apresentar aos olhos daqueles que o aguardam.

${ }^{80}$ Ser e tempo, Vozes, p. 57.

${ }^{81}$ Ibidem, p. 61.

${ }^{82}$ Ibidem, p. 65.
} 
ontologia fundamental, que possui como tema a pre-sença $[\text { Dasein }]^{83}$, isto é, o ente dotado de um privilégio ôntico-ontológico". ${ }^{84}$

Apontando para a grande obscuridade do método da ontologia tradicional que foi a grande contribuinte para o esquecimento da questão do ser na história da filosofia, a ontologia fundamental, tendo uma base tríplice (volta às origens do pensar do ser; a relação da existência com uma nova noção de tempo e temporalidade e a questão da hermenêutica) é um tentativa de evidenciar que o Dasein não encontra uma adequada definição de si senão em função do seu próprio ser, marcada pela relação com o ser.

É na busca ${ }^{85}$ que se conhece o ente e o ser. Buscar é se colocar a caminho, desejar, disponibilizar-se para o fenômeno do ser.

É nesta busca, neste caminhar, que o ente, querendo, revela a sua interioridade, assim como é no caminhar pela trilha (Weg - Holzwege, ou seja, a trilha do lenhador) que se percebe a manifestação ${ }^{86}$ da vida que palpita no interior da floresta (e somente quem caminha a trilha, percebe).

Caminhar por uma trilha não quer significar necessariamente que se sabe onde ela termina. Ao contrário, em algumas trilhas não há certezas, mas somente assombro pelo surpreendente conhecimento novo que o caminhar na trilha traz consigo. Nas palavras de Guimarães Rosa: “mestre é aquele que de repente, aprende”.

É a matéria quem determina o seu possível contorno (como a argila que se deixa compor). De igual maneira, também é o direito.

${ }^{83}$ Como Jeannette Antonios Maman apontou em suas aulas na pós-graduação que a edição brasileira foi infeliz ao traduzir Dasein por "pre-sença" e também não acertou nas noções de existencial e existenciário que estão invertidos, equívocos que levam a uma interpretação errônea de Heidegger e que não foram percebidos sequer na revisão do texto. Portanto, toma-se a liberdade de onde a edição brasileira anotou "pre-sença" substituir Dasein. Dasein significa a existência típica do ser humano que apresenta a possibilidade de ser capaz de ir ao encontro do desvelamento dos entes e de seu ser e, inclusive, apropriar-se de si mesmo.

${ }^{84}$ Ser e tempo, Vozes, p. 68.

${ }^{85}$ Expressão das mais conhecidas de Jeannette Antonios Maman é sua definição: "O Direito como pesquisa do justo". Influenciando pesquisas e pensamento posterior a sua obra, Jeannette Antonios Maman acredita na busca, na investigação, criatividade da atividade jurídica, que parte não do indivíduo isolado, mas da sociedade na busca do reconhecimento e respeito das diferenças. "A busca pela verdade se dá em diversas sendas, caminhos, trilhas. Basta ter olhos de ver e ouvidos de ouvir, para, envoltos pelos eventos (o 'événement' dos franceses como em 1968), sermos levados à frente, como seres resolutos".

${ }^{86}$ Quanto à palavra manifestação, ver Ser e tempo, p. 60. Na obra Fenomenologia Existencial do Direito, Jeannette Antonios Maman substitui "manifestação" por "expressão". 
"Há a primazia do ser sobre o consciente. Há o primado do real, do existencial sobre o consciente, onde se inclui as formas jurídicas, manifestação ideológica ao nível da superestrutura." ${ }^{87}$.

Aquele que não se põe a caminhar na investigação do ser (do ente) se acerca apenas para as construções ideais soltas no ar resultantes da opiniões, a forma de doxas.

Desta forma, em Heidegger, percebe o significado originário do fenômeno: se revelar àquele que se dispôs em conhecê-lo.

Afirma-se em seu significado originário porque na língua grega (Heidegger observa que importa é a experiência contida na palavra ${ }^{88}$ ) o termo fenômeno é derivado do verbo mostrar (melhor, $\phi \alpha \imath v \varepsilon \sigma \tau \alpha \iota$, mostrar-se), entendido como aquilo que se revela não só na sua aparência, mas também na sua interioridade. Fenômeno é, portanto, des+cobrir ( $\alpha \lambda \eta \theta \varepsilon v \varepsilon \imath v)$, tirar o véu que cobre o ente existente para quem se põe a desvelar.

O que Heidegger propõe é o conhecer do fenômeno jurídico não a partir de um pensamento racional-eidêtico, mas da sua apropriada experiência, apostando no direito da vida, nas lógicas das condições da vida experimental entendido aqui como experiência, como mundo vivido.

Heidegger propõe uma viagem de conhecimento a partir do experimentalmente histórico.

$\mathrm{Na}$ fenomenologia que nos propõe, a experiência é fundamental: é, ao mesmo tempo, busca e encontro daquilo que é próprio do ente.

"Heidegger não se satisfaz com a reflexão conceitual, como se as ideias tivessem vida própria e nossa existência individual e social fosse secundária. $\mathrm{O}$ Dasein (o ente humano existente) mostra que o homem não é um animal racional ou um ente divino (no qual a alma é em comum com o divino); o homem é um ente que está na existência (que é a mesma coisa que dizer: está

${ }^{87}$ Jeannette Antonios Maman, Fenomenologia existencial do direito, p. 53.

${ }^{88}$ A palavra não é um significante, mas simplesmente é. Não é ligação, sintaxe, mas é morada do ser. 
desde sempre), percebe que sua existência já estava aí antes de ele começar a pensar." 89

O fenômeno jurídico (o em-si da coisa em sua manifestação) se revela na complexa relação entre as palavras do direito e a semântica na realidade.

"Desse modo, fenômenos nunca são manifestações, toda manifestação é que depende de um fenômeno" $"$.

Na filosofia heideggeriana, que compreende o fenômeno jurídico a partir da experiência, esta realidade não é tão só instrumento para compreensão do jurídico que meramente lhe dá um significado, mas é verdadeiro instrumento de e para a transformação deste, na identificação da unidade entre teoria e prática e na tentativa de descobrir naquilo que ele permite ser conhecido.

Aí se encontra a sua importância: a tentativa de apontar para uma consciência do fenômeno jurídico que foi ocultada pelas correntes tradicionais do pensamento ocidental.

Uma questão a ser trabalhada é a possibilidade de refletir o fenômeno do direito (direito e justiça, que se desenrola no contexto histórico que oculta e revela) como expressão do existencial ou do existenciário.

"Existenciaridade caracteriza o ser do Dasein, as estruturas que o constituem ontologicamente. Existenciário difere de existencial; este designa os modos de ser do Dasein, na sua projeção ôntica. Os caracteres existenciários se opõem às categorias que se atribuem aos demais entes - que não são como é o Dasein. A existenciaridade do Dasein será revelada a partir da análise de sua projeção existencial" $"$ 91.

Portanto, é necessária a observação dos termos para se evitar confusão que persiste até em obras traduzidas ${ }^{92}$.

\footnotetext{
${ }^{89}$ Jeannette Antonios Maman, Fenomenologia existencial do direito, p. 53.

${ }^{90}$ Ser e Tempo, Vozes, p. 59.

91 Juliana Morais Bicudo, A investigação fenomenológica da liberdade em martin heidegger, p. 22.

92 Jeannette Antonios Maman aponta que na obra Ser e Tempo de publicação da Editora Vozes, onde se lê "existenciário", se deve ler e entender "existencial" e vice versa.
} 
É existencial (ôntico, mundo do ente) o inautêntico, o cotidiano, o impessoal, o mundano, a vidas dos afazeres. O inautêntico mal vive, porque não vive para suas possibilidades.

A vivência inautêntica está continuamente a mercê da opinião dos outros (“eles"), das suas decisões e padrões de comportamento.

Existenciário (ontológico, mundo do ser) é o autêntico, o extra-ordinário, aquilo que dá autenticidade, que realiza as possibilidades de cada qual, realizando a existência concreta do Dasein, numa co-existência, na referência da constituição intrínseca da existência humana, como comunidade em integração social.

Aqui o social tem primazia tem primazia sobre o individual, embora este seja abraçado pela liberdade como destino.

"Um ente que indaga ou questiona o Ser, interrogando em primeiro lugar o seu próprio Sein, é um Da-Sein. O homem é homem porque é um 'ser-aí', um 'éaí'. O ôntico realiza Da-Sein indagando o ontológico. E fá-lo, única e necessariamente, por meio da linguagem. (...) Questionar o Sein é questionar o seu Sinn - o seu 'sentido', o seu 'significado', o seu 'propósito",93.

Distintos, o primeiro traduz um direito como técnica e desvinculado da realidade a que se aplica. Já o segundo, o relaciona às necessidades mais próximas do homem.

Contudo, embora distintos, não são contraditórios (inautêntico não traz o sentido de não-autêntico, mas é uma forma distinta de ser-no-mundo, de apreender o cotidiano) e um não faz sentido sem o outro.

Ambos são, sim, manifestação de um único e mesmo fenômeno do ente que se revela e encobre ${ }^{94}$.

Contudo, o ente só pode ser aquilo que autenticamente ele é. Fora disso, forçoso dizer que ele usa uma máscara. É uma farsa de si mesmo, na anulação de suas possibilidades.

\footnotetext{
${ }^{93}$ George Steiner, As idéias de heidegger, p. 72-73.

${ }^{94}$ Pantatàónta, ou seja, tudo é um, todo o ente é no ser, ou melhor, o ser é o ente.
} 
Mas, como tudo é um, e também numa crise é possível se ter o aspecto positivo de peneirar o que é fundamental, é na situação de inautenticidade que o Dasein, tomando consciência da perda da autenticidade, retoma sua única luta a qual é forçado: se esforçar para voltar ao ser autêntico, assumir sua liberdade como destino. Sua resolução como desconstrução do que impede de ser livre e autêntico.

"Por isso, quando buscamos o ser do direito, vamos encontrá-lo na estrutura ser-no-mundo-com-o-outro. O ser do direito não é o total nem o individual - é a estrutura originária do ser-aí como afirmação de co-existência.

A ontologia tradicional leva água para o moinho dos universais ou do individual. Ao contrário, na ontologia fundamental de Heidegger, o homem não é só ele ou o exterior - é as duas coisas."95

Os termos são de importância: o conceito de valor é sempre ideológico e, por isso, também arbitrário, não se conhecendo na sua interioridade.

O problema do valor é que ele está sempre subordinado a uma filosofia e, esta, a uma ideologia que o traz e ao qual segue sem questionar. Se o conceito estiver ligado à existência, ele deixa de ser um valor e se torna uma necessidade.

Os gregos pensavam em termos existenciais: pensavam sobre o mundo fenomenológico (que experimentavam). Para eles, era fundamental a inserção no mundo, e, assim, eles descobriram o universo como ordem (cosmogonia, cosmologia), sendo que o seu direito (num lugar bem determinado: a pólis) se definia cotidianamente, numa prática reiterada.

Por estas razões é que se pode afirmar que o existencialismo é um humanismo: agora, o humano é no mundo existencial, entendido como ser-no-mundo-como-outro-para-a-morte, no desenvolver da vida cotidiana e na transcendência de suas possibilidades.

A pergunta que vale fazer é: por que o direito é o que é e não outra coisa? Da mesma forma como Heidegger fez com a própria filosofia: Que é isto, a Filosofia? Ou então, como é conhecida a questão em Leibniz: por que é que existe o ser, de preferência

\footnotetext{
95 Jeannette Antonios Maman, Fenomelnologia existencial do direito, p. 80.
} 
ao nada? De certo é que todo conhecimento parte do assombro diante uma pergunta que leva a um Ursprung, ou seja, a um salto ${ }^{96}$ originário.

De certa forma, sem indagação incessante (quase que traumática) que provoca e coloca a co-responsabilidade do necessário ser-com-o-outro, não pode haver "humanidade" digna de receber este título.

E se Heidegger estiver certo e for na relação com o outro que acontece o co-existir do ente, isto é igualmente válido (e principalmente também válido) para o direito, pois a filosofia do direito deve procurar o direito enquanto é.

Trata-se do direito como fenômeno que passa a existir, e que aparece como co-existência e comunicação.

Enquanto fenômeno que existe, o Direito tem dois aspectos de interesse: i) sua aparência, o que ele não é; ii) sua essência: o que ele é, existencial, não o direito ideal, mas aquele do cotidiano. $\mathrm{O}$ direito é comunicação e discurso.

Que é o direito não está mais na sua forma (eidos), mas na sua existência (como se desvela). Mas, o que altera o desvelamento do direito: a sociedade ou o indivíduo?

Em Kant, por exemplo, certamente é o indivíduo e seu imperativo categórico.

Em Heidegger, pelo contrário, é a sociedade, vez que nunca se tem o ser isolado, porque é ser-com originalmente. Aqui nasce a questão do trabalho, da subjetividade em Heidegger.

O direito trata de pessoas que são entes entre outros entes. Assim, o indivíduo, por si só, não muda a realidade em que vive.

O ser humano é dado no mundo, com os outros, não como indivíduos juntos (partes somadas), mas como um todo (numa humanidade ${ }^{97}$ ).

\footnotetext{
${ }^{96}$ Nicola Abbagnano ao apresentar as várias noções de "salto" apresenta entre elas: "Termo empregado por Kierkegaard para indicar a 'passagem qualitativa', brusca e sem mediação de uma categoria para outra ou de uma forma de vida para outra (p. ex., da vida ética para a vida religiosa) ou, em geral, de um estado para outro (p. ex., da inocência para o pecado, do pecado para a fé, etc)..." - verbete.

${ }^{97}$ Reconhecida no outro, numa existência comum.
} 
O seu modo de ser é o da faticidade (mundo do Dasein, a sua estrutura ontológica) e não o da fatualidade (mundo dos dados) ${ }^{98}$.

Ou nas palavras de um ditado da cultura comum: "se não soubermos o que somos hoje, como saberemos o que seremos amanhã?".

Existir é uma maneira de ser originária com uma qualidade: compreensão, que se adquire olhando sempre para o passado, buscando e investigando-o. Assim, a história não está morta e se projeta para o futuro. Olhar para trás é compreender e olhar para frente é viver. O passado caminha a nossa frente, como ensina Heidegger.

Portanto, há uma dicotomia que pode vir se revelar de um modo autêntico e outro de modo inautêntico ${ }^{99}$.

Kant funda o inautêntico: o direito como possibilidade sempre à frente, sem superação, nem síntese, mas uma constante ampliação do conhecimento jurídico.

Típico pensador alemão iluminista do século XVIII, abraçando o individualismo (quem conhece é o indivíduo e, portanto, subjetivo), baseia todo o seu sistema no sujeito. O sujeito não conhece o objeto, mas seus fenômenos, ou seja, aquilo que se apresenta aos sentidos do sujeito. Sem possibilidade de se chegar ao noumero, Kant não se preocupa com a essência do ser ${ }^{100}$.

Mas, como se percebe a coisa em si ou se pode ao menos dizer que não é apresentado o justo em si, mas a algo que o expressa (apresenta) como sendo justo?

Kant irá trabalhar isto nas ditas questões da vida prática: Crítica da Razão Prática; Crítica dos Juízos e Metafísica dos Costumes.

Ele parte de um postulado: que nenhum conhecimento é dado fora do homem, mas é dado pelo homem.

Assim, por exemplo, a lei divina não é a lei de Deus para o homem, mas é algo que o próprio homem cria.

\footnotetext{
98 Saliente-se que não há um corte entre eles, dicotomicamente, mas apresentam apenas diferença didática. São elementos da mesma coisa.

${ }^{99}$ Este é impelido pelo competir e devorar e, seu último passo, é o consumo do mundo.

${ }^{100}$ Todavia, apesar de partir de um fundamento empirista, a filosofia kantiana conserva o racionalismo.
} 
É a razão humana a responsável por elucidar aos litígios afetando razões que a mesma razão aceita como verdadeiras. O último fundamento é Deus.

Deste modo, ele chega ao imperativo categórico, máximas de uso universal, pois racionais.

Contudo, a filosofia do direito de Kant, quando busca e alcança um conceito de lei universal, esta é essencialmente uma busca de uma filosofia do direito burguesa-moderna ${ }^{101}$, uma visão universal de direito e de justiça alcançada que oculta uma visão social de classes.

Enquanto o empirismo conduz a uma sensibilidade, o racionalismo conduz ao mundo inteligível. E, assim sendo, para o Direito, a razão deve prevalecer sobre a sensibilidade. Por consequência, se cria um direito e uma justiça baseados no fruto da pura racionalidade humana ${ }^{102}$ e no qual o real do direito é diferente do real dos fatos.

"Preferimos dizer que o direito é fenômeno. De qualquer forma, o que importa não é acumular fatos, mas sim interpretá-los"103.

Porém, mesmo depois de Kant, para o jurista persiste a questão: por que obedecer? Os entes se revelam pelos caminhos das perguntas feitas.

A Filosofia do Direito não deve ter a tarefa de alcançar justificativas racionais para a prática de um direito e de uma justiça capitalista-instrumental. Ela tem por objetivo pensar o conhecimento do Direito positivado, rompendo com as posições dogmáticas, especialmente positivas.

E isto se faz por meio do espanto (thaumazein) que nos detém.

Só há questionamentos com o assombro, com a perturbação.

A perplexidade gera a curiosidade que faz perguntar: por que as coisas são assim e não de outro modo (ou para este estudo, por que o direito é assim)?

\footnotetext{
${ }^{101}$ A burguesia, conforme atinge o poder, não pode permitir uma justiça que aceite a separação de classes. Busca, ao contrário, o universal, também para eliminar os privilégios dados aos reis e nobreza.

102 Comumente chamada como regra de ouro: "O que quereis que os homens vos façam, fazei-o também a eles” (Evangelho de Jesus Cristo segundo Lucas, capítulo 6, versículo 31). De igual forma, ver Evangelho de Jesus Cristo segundo Mateus, capítulo 7, versículo 12.

${ }^{103}$ Jeannette Antonios Maman, Fenomenologia existencial do direito, p. 44.
} 
A indagação é o ponto de partida metodológico de Heidegger que privilegia a investigação, como se pode entender ao ler o $\$ 7 .^{0}$ de Ser e Tempo.

É duvidoso afirmar que quem pensa, quem age, age, dicotomia esta oriunda tão somente a partir do mundo moderno de Kant.

Para se afirmar que pensar é coligar representações numa consciência, se deve atentar que, para a modernidade, consciência quer significar uma reflexão interna do indivíduo e, como se o exercício da capacidade da racionalidade possibilita o desenvolvimento social.

Pensar e agir não são e não estão separados. Teoria e prática formam uma só identidade, uma só unidade.

O mundo compartilhado ${ }^{104}$ nos mostra que o mundo jurídico nos é dado com o outro que pode ser autêntico ou inautêntico, em sentido contrário ao do dogmatismo. O mundo da convivência é e deve ser o ponto de partida para a reflexão jusfilosófica.

No desvelar $(\alpha \lambda \varepsilon \tau \eta \varepsilon ı \alpha)$ da sua situação existencial está o sentido libertário do direito.

"É assim que devemos ver o direito não somente como criação da sociedade, da cultura. $\mathrm{O}$ fundo existencial do direito tem como traço distintivo o servir a entes-para-a-morte que, derrelictos, procuram, em relação, sobreviver para viver. A sobrevivência passa pelo econômico, que é um modo de ser, e não um modo de ação do poder. Nisto consiste a universalidade do direito"105.

\section{a) Constituição do Dasein}

O mundo dos entes é a totalidade dos entes existentes. Mas, nesta totalidade só o ser humano é aquele que consegue dar um passo à frente e, além de existir, sabe que está com o outro no mesmo sentido, inseparável da temporalidade que vive.

\footnotetext{
${ }^{104}$ A existência se manifesta como totalidade.

${ }^{105}$ Jeannette Antonios Maman, Fenomenologia existencial do direito, p. 85.
} 
E o direito é característico ao Dasein, visto que o fenômeno do direito também se baseia na característica ontológica do Dasein, no seu modo de ter de ser que se projeta, como que uma imposição, a sua frente, para fora.

Como numa clareira, o observador não fixa seu olhar na abertura da vegetação, mas, remetendo para fora de si, se assombra com tudo mais o que floresta faz se desvelar ao redor dela.

O Dasein (ser-o-aí ${ }^{106}$, ser em projeção) é a estrutura do ser. Sua essência (o existir) é aquilo que aparece (desvela) e aquilo que se esconde (vela), em suas várias capacidades. É o ser que tem uma só constituição, a do ser humano existente, sempre em situação, porquanto todos já nasceram numa situação histórica definida.

Dasein é o homem existente (aquele que é sendo) enquanto modo de ser, enquanto processo de constituição ontológica ${ }^{107}$. E enquanto modo de ser é cuidado que se manifesta como se ocupar (impessoalidade, ser-com-o-outro ${ }^{108}$ ) e se preocupar (ocupação que respeita a originalidade do que se toma $)^{109}$.

"Não é que o direito (a busca do justo) possa prescindir de regras. Elas são necessárias, desde que o direito que aí esteja relatado (entendendo-se a regra como o relato breve da coisa justa) seja emergente da justiça (virtude) com os olhos voltados para o econômico. Neste sentido, o justo é a verdade; e o econômico é identificado com a verdade ontológica. A ponte entre o justo e a verdade é o cuidado, a necessidade de sobreviver no cotidiano mundano; e muito mais do que isto, o justo, autenticamente, é a realização do ser, em geral e de cada um."110

O Dasein é também finito, destinado para a sua decadência (a última possibilidade é uma impossibilidade: a morte) e é lançado (ao ter que existir) ou resoluto (não abandonado, mas entregue ao destino, mas com uma probabilidade de reação ou resistência) na realidade mundana. Está no mundo e o mundo está nele, antes, diante e depois.Se o ser é a fonte de luz, a coisa a ser vista é o ente e quem vê é o Dasein.

\footnotetext{
${ }^{106}$ Heidegger aceita a tradução francesa de dasein: être-le-là. Mais adiante será utilizado somente "ser-aî".

${ }^{107}$ Estrutura ontológica é o mesmo que estrutura original.

${ }^{108}$ Não se fala mais em essência, mas em condições.

${ }^{109}$ Cura - cuidado - preocupação.

${ }^{110}$ Jeannette Antonios Maman, Fenomenologia existencial do direito, p. 90.
} 
"O ser-no-mundo já é sempre numa de-cadência"."111

Como apontado em nota de rodapé, Jeannette Antonios Maman traz que, portanto, ao contrário do que se apresenta na tradução brasileira de Ser e Tempo, Dasein não se traduz por pre-sença ${ }^{112}$. Ele é o sempre ser-aí, homem projetado, em situação.

E é somente na totalidade dos entes existentes que está o Dasein, porquanto, por sua própria característica fundamental, não existe isolado ${ }^{113}$. Ele é profundamente relação, é ser-com-outro, é sociabilidade. Dasein é sempre ser-aí-com, vez que remete para revelar os entes aqui e acolá. Não é, mas está junto dos entes, numa situação existencial da qual ele não pode escapar.

\section{Temporalidade}

O Dasein pertence ao seu tempo, ao seu momento. Fora do seu tempo, sua existência não tem nenhum sentido.

À medida que o Dasein se conscientiza do seu tempo, o mundo também é. Assim, a temporalidade não é um receptáculo onde o Dasein se coloca ou é por outros colocado. A temporalidade deve ser entendida como uma atividade, uma ação do Dasein.

Deste modo, não seria a melhor opção entender que se decide antes o que ou quem é para, então, decidir o que se fará; ao contrário, se descobre o que ou quem é a partir do mundo que o cerca.

E nem mesmo na sua finitude, o Dasein deixa o seu tempo porquanto que a morte, longe de ser um recomeço ou um fim, é o continuar da existência. O homem técnico se esqueceu do aprendizado da morte e dela procura fugir, desde o pensamento racional-iluminista que tudo quer dominar e que já não serve mais ${ }^{114}$.

\footnotetext{
${ }^{111}$ Martin Heidegger, Ser e Tempo, Vozes, p. 244.

112 No século XVII, o infinito era substantivado como (das) Dasein, no sentido de presença.

${ }_{113}^{113}$ Pode-se afirmar que o plural de Dasein é ser-com.

${ }^{114} \mathrm{O}$ homem já não é mais o senhor da natureza, mas é parceiro dela. Atualmente, no direito, já se vislumbra a possibilidade da natureza e dos animais serem tomados como sujeitos de direito, já existindo, inclusive, decisões de habeas corpus em favor de chimpanzés presos em zoológicos ou circos.
} 
A morte física, que sempre nos faz lembrar a nossa temporalidade (aprendizado que já se inicia na tenra idade quando se acompanha o falecimento dos familiares),não deve produzir a sensação de agonia.

Sendo parte da vida, ela deve ser tratada com uma arrebatadora indiferença: é, ao mesmo tempo, normal e nos transporta num êxtase para a transcendência do existir no mundo com o outro e não para o existir individualista (eu vivo, eu morro, eu me salvo).

Heidegger vai afirmar que a constituição existencial-ontológica do Dasein está constituída na temporalidade.

A temporalidade típica do Dasein ensina que ninguém deve passar despercebido ao lado da existência de cada um. Cada qual é responsável também pelo outro.

\section{Circumundanidade}

O mundo constitui existencial e existeciariamente o Dasein que, como visto, não é um sujeito, não é uma pessoa, não é um "eu”.

A questão do eu não entra no pensamento heideggeriano (o que vai a sentido contrário da opinião de Habermas). Para Heidegger, Dasein é ser-no-mundo-como-outro (In-der-Welt-sein).

Mas não é um simples estar-no-mundo-com-o-ouro, mas um real ser-nomundo-com-o-outro. Totalmente imerso no mundo, primeiro assombro e origem de todas as perguntas.

\section{b) Autêntico e inautêntico}


Tradicionalmente denomina-se autêntico de modo positivo como sendo aquilo que é legítimo, real ou verdadeiro. De modo negativo, não foi falsificado ou sofreu alguma corrupção.

De outra forma, poder-se-ia afirmar que autêntico é quando se estabelece uma identidade certa e positiva sobre aquilo que se supõe ser.

$\mathrm{Na}$ filosofia, os termos foram utilizados por vários pensadores especialmente à existência humana e a outras realidades, mas apenas na medida em que estejam em função dessa existência.

Acima, houve uma rápida referência. Agora, deve-se perguntar o que Heidegger diz sobre os termos de uma forma um pouco mais extensa.

Heidegger utiliza os termos para definição daquelas situações intrínsecas e básicas do existir para resolver o estado desejado pelo Dasein, realizando a sua característica de ser possibilidade: o inautêntico (Uneigentlich), o cotidiano, perdendo a si mesmo, ou o autêntico (Eigentlich), o extraordinário, ganhando a si mesmo.

Porque o ser do Dasein "é sempre e cada vez meu" (que não quer dizer que seja próprio - zu eigen), somente o Dasein pode ser autêntico ou não. Todo o resto o é em afinidade à autenticidade ou não do Dasein.

Os termos refletem duas situações de existir e não necessariamente dois estados de moral ou de teologia como poderiam ser levados a ser identificados; um céu, bom, outro inferno, mal, nem mesmo se poderia buscar ver entre eles um grau de superioridade ou dicotomia.

Por ser essencialmente possibilidade de ser, o Dasein pode escolher o que ambiciona: se ganhar ou se perder. Ganhar ou perder não está no sentido de ter recebido ou ter algo sumido. O Dasein não ganha ou perde algo como se ganha ou perde um prêmio ou objeto. Ele se perde quando cai na ocupação do cotidiano e é absorvido pelo mundo, esquecendo de si mesmo, interpretando a si não como ente autônomo, mas diante das inquietações cotidianas.

“O ente, em cujo ser, isto é, sendo, está em jogo o próprio ser, relaciona-se e comporta-se com o seu ser, como a sua possibilidade mais própria. A pre-sença [Dasein] é sempre sua possibilidade. Ela não 'tem' a possibilidade apenas 
como uma propriedade simplesmente dada. E é porque a pre-sença [Dasein] é sempre essencialmente sua possibilidade que ela pode, em seu ser, isto é, sendo, 'escolher-se', ganhar-se ou perder-se ou ainda nunca ganhar-se ou só ganhar-se 'aparentemente'", 115

Mas o Dasein nunca estará definitivamente no inautêntico, porque este é um modo de existir que sempre pode ser modificado.

Mesmo na inautenticidade, o Dasein se ocupa daquilo que é "meu", próprio dele. Se assim não fosse, ele deixaria de ser sendo, o que não é possível. O que lhe acontece é que o Dasein existe na impessoalidade onde interpreta a si mesmo em função do cotidiano que experimenta.

Mas o Dasein não está necessariamente sujeito ao impessoal e pode escolher fazer ou não sua própria coisa, firmando-se sobre os próprios pés.

Mas esta escolha em nada é particular, individual ou subjetiva.

O autêntico será encontrado em nós - não no eu, ou seja, a pergunta essencial do Dasein, sobre a essência da verdade (no caso, jurídica) passa pela questão, pela pergunta feita ao coletivo, não ao indivíduo.

É próprio do Dasein ser ser-o-aí-no-mundo (o hífen é um recurso muito utilizado por Heidegger para unir as palavras para dar um sentido único).

Portanto, não há ser humano existente senão no mundo e não há mundo sem o ser-existente.

\section{c) Mundo e mundanidade}

Heidegger coloca que o Dasein é ser-com-o-outro-no-mundo. Portanto, cabe buscar um melhor entendimento de que seria "mundo".

Em filosofia, a noção de "mundo" possui vários significados, sendo que os mais empregados são no sentido de conjunto de todas as coisas, sejam elas criadas ou

${ }^{115}$ Ser e tempo, Vozes, p. 78. 
não; conjunto das entidades de uma classe, como Platão indica com o mundo das ideias, ou no sentido de um espaço em perspectiva onde se encontram certos conhecimentos e coisas, como, por exemplo, o mundo do mito.

O primeiro foi mais utilizado no início da filosofia antiga, evoluindo para

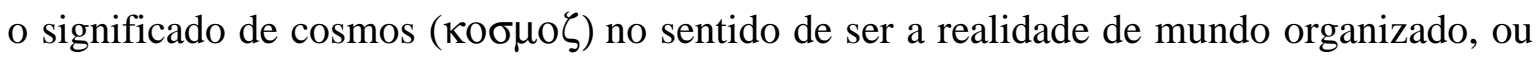
seja, realidade fruto de uma inteligência de ordenamento de tudo.

Mais tarde, em Platão, ocorre a famosa dicotomia de mundos: mundo inteligível e o mundo sensível que, contrapostos, na realidade, formam uma unidade como percebidos pela existência humana, pois, embora distintos, conservam uma relação íntima com o ser humano que é o único capaz de perceber e viver ligação da realidade destes mundos.

Com o cristianismo, a dicotomia entre os mundos continua, mas não nos moldes do pensamento antigo. Na visão cristã, este mundo é criação do mesmo Deus ${ }^{116}$ que, transcendente, habita no outro mundo, o reino divino.

O cristão, apesar de viver neste mundo e ter ciência que, antes de tudo, ele é habitante da cidade eterna, noutro mundo, não o despreza, mas trabalha com ele para que possa continuar o engenho das criaturas iniciadas por Deus. Cada cristão se sente um continuador da obra divina iniciada no Gênesis bíblico.

Portanto, o cristão não deseja abandonar o mundo, mas transformá-lo, sendo algo plenamente possível, segundo dois dos maiores doutrinadores cristãos, como dizia Agostinho, amar a Deus no mundo ou Tomás de Aquino com o ensino de ser possível reconhecer o criador na grande pintura do mundo.

Kant apresentava a acepção com duas expressões: mundo e natureza que nem sempre diferem entre si. Por mundo se tem a soma de todas as aparências e a totalidade de sua síntese; por natureza, o mesmo mundo anterior como um todo vivo e ativo.

\footnotetext{
${ }^{116}$ Assim se encontra no credo cristão: creio em Deus Pai, todo poderoso, criador do céu e da terra, ou seja, criador de tudo o que existe.
} 
Em Heidegger, a noção pode apresentar várias significações, como termo ôntico que indica a totalidade dos entes; o termo ontológico indica o ser dos entes; o termo ôntico referente ao Dasein; ou mesmo o termo ontológico-existencial da mundanidade.

Destas, as duas últimas são as de maior relevo, porque se percebe nelas o sentido da compreensão do Dasein como ser-no-mundo, onde o mundo não pode ser entendido como uma coisa ou como uma totalidade de coisas que recebe o Dasein. O Dasein está no mundo que não lhe coisa objetiva.

Nicola Abbagnano diz que:

“A esta mesma noção está ligada a de Heidegger, aceita pela filosofia existencialista, de M. como campo constituído pelas relações do homem com as coisas e com os outros homens. Heidegger diz: 'É tão errôneo utilizar a palavra M. para designar a totalidade das coisas naturais (conceito do M. naturalista) quanto para indicar a comunidade dos homens (conceito personalista). O que de metafisicamente essencial contém o significado mais ou menos claro de M. é que este visa à interpretação do Dasein humano em sen relacionar-se com o ente em seu conjunto' (...). Obviamente, desse ponto de vista, a palavra M. faz parte integrante da expressão "ser-no-M", que designa o modo de ser do homem 'situado no meio do ente e relacionando-se com ele', ou seja, em relação essencial com as coisas e com os outros homens. Nesse caso, M. significa o conjunto de relações entre o homem e os outros seres: a totalidade de um campo de relações". 117

Apesar de variada opções, na sua forma mais conhecida, Heidegger opera o termo "mundo" (Welt) sempre em relação ao Dasein, colocando-o no mundo e, ao mesmo tempo, sendo um mundo.

O Dasein é essencialmente ser-no-mundo (In-der-Welt-sein), sendo esta a principal maneira do Dasein se lançar na existência.

“'Ser en’ es, según esto, la expresión existenciaria formal del ser del 'ser ahi', que tiene la esencial estrutura del 'ser em el mundo",.118

\footnotetext{
${ }^{117}$ Dicionário de filosofia, verbete.

${ }^{118}$ Ser e tempo, Fondo de Cultura Económica, p. 67.
} 
Muitas vezes Dasein e ser-no-mundo quase que se equivalem no texto heideggeriano que aprecia a utilização da expressão Mitwelt, ou seja, mundo-com, relação com alguém, em recusa na utilização das expressões Umwelt (o mundo em volta) e Selbstwelt (o mundo próprio)

As demais coisas que não são Dasein só estão dentro do mundo ou só pertencem ao mundo.

Perceba que continua o questionamento inicial: qual é o sentido do ser?

Desta forma, se compreende a noção de mundanidade que quer transmitir exatamente qualidade do que é mundado, como o Dasein o é.

A mundanidade exclusivamente se deixa assinalar por meio de uma compreensão daquele ser para quem existe um mundo porque é-com. É no mundo que o Dasein mora. Mas não mora sozinho, mora-com-o-outro, vive-com-o-outro, existe-com-ooutro.

Compreender a relação com este mundo é buscar a compreensão da própria existência. A saída de si mesmo para a busca do fenômeno do mundo é possibilidade de compreensão para o Dasein. Sozinho, ele não se conhece e não realiza a sua existência.

É nesta relação com o mundo que o ser-com-o-mundo se conhece.

Se só do Dasein tem mundo e participa do cotidiano do mundo em volta promovendo um significar das relações, mundanidade é, então, estrutura ontológica, o modo como o Dasein se abre ao mundo, dando-lhe significância.

Contudo, nenhum modo da mundanidade é, em si mesmo, decisivo para constituir o sentido do ser do ente na sua totalidade. Nenhum mundo concreto de articulação da significância consegue esgotar as possibilidades que possam ser esboçadas. 


\section{Capítulo III - A crítica à metafísica (pensamento filosófico moderno)}

Costuma-se entender "metafísica", entre outras definições, como sendo o estudo das causas primeiras ou últimas e a origem do termo liga-se muito mais a um critério prático de organização de livros em biblioteca do que uma classificação racional. Desta forma, o nome, á princípio, não possui nenhuma relação, mais ou menos profunda, com o conteúdo da matéria estudada.

Para alguns, as raízes da metafísica se encontra nos pré-socráticos que buscavam o elemento fundamental na natureza, muito embora ainda mais fixados no campo material, com exceções de Heráclito e Parmênides.

Platão é o grande sacerdote da metafísica e Aristóteles a definia como sendo a filosofia primeira.

Atualmente, um das definições aponta como sendo a ciência que estuda aquilo que está além da experiência imediata, sendo esta experiência entendida como aquela dinâmica no tempo e espaço.

Independente disto, certo que a metafísica determinou os caminhos do pensamento ocidental, tendo como marca do início de sua queda de importância filosófica com o nominalismo e o embate entre empirismo e racionalismo.

Para responder a pergunta “qual o sentido do ser?” Heidegger terá que se romper com toda a metafísica anterior e trilhar investigações fenomenológicas que vai mostrando que não existe um interior e um exterior.

Heidegger demonstra que a pergunta foi esquecida pela metafísica tradicional pelo motivo que a metafísica tenha se transformado numa ontologia que tem como ponto de partida e paradigma do conhecimento verdadeiro o se apodera da coisa como aquilo que é.

Houve o esquecimento que o Dasein está sendo no mundo e as coisas, entes simplesmente dados, vão se desvendando por já estarem abertos e passíveis de manualidade. 
A investigação do sentido do ser deve começar por onde?

Heidegger diz que deve se começar pelo cotidiano.

E o que mais se tem de coloquial e habitual é o próprio Dasein, porque é ele que coloca a questão do ser.

Para tanto, a análise da estrutura do ser no mundo é o cenário onde se pode atingir com possibilidade de compreensão da questão que Heidegger se propõe.

A maneira como Heidegger aborda o ente e o sentido do ser, no desenvolvimento da sua ontologia fundamental, se tornou marco na filosofia do século XX.

Qualquer que seja o modo pelo qual se comenta o ente, quer como espírito no sentido do espiritualismo, quer como matéria e força no sentido do materialismo, quer como vir-a-ser e vida, quer como vontade, substância ou sujeito, quer como 'energia' ou quer eterno retorno do mesmo, todos os casos o ente aparece como ente $\underline{\text { à luz do Ser. }}$

Ser com letra maiúscula como o medieval Seyn é o Ser de todos os entes, como sentido, como significado. Quando o Dasein - o ser-o-aí, no sentido de ser projetado, ser lançado fora de si, existir fora de si (no mundo e como o mundo) é característica do serhumano-existente-no-mundo-com-o-outro (sem ser considerado como sujeito-isolado).

É assim que o término da crítica à metafísica, ou fim da filosofia ocidental se chega, de modo arriscado, à morte do sujeito "moderno". A tábua de valores, a moral imputativa, ao centro do universo característico pela razão e pelo cálculo do HOMEM, utilitário, produtivo, desumano.

A partir de um histórico sobre a subjetividade jurídica e o sujeito de direito, a partir da primeira colocação de Heidegger, da filosofia do ser, e da analítica existencial, se chega a uma conclusão não só sobre o tema histórico do sujeito de direito e da subjetividade jurídica, mas também do tema filosófico que foi desenvolvido e, ainda mais, da possibilidade de desconstrução repensada de como poderia ser essa "subjetividade" do ser-com numa comunidade onde o social prevalece sobre o indivíduo. 
Quando se desenvolveu uma teoria do sujeito, como dito antes, a racionalidade era a tábua de valores: é esta subjetividade moderna, este egoísmo do homem moderno, a alienação deste sujeito que se critica.

Se persistir nesta situação, persiste o inautêntico, desconhecendo e alienado da sua própria vivência social, desta imensa fenda que separa o sujeito, vivendo como uma célula isolada, uma mônada.

Quando Heidegger fala de fenômenos como acontecimento é o que em alemão (Ereignis, ou seja, acontecimento, evento, ocorrência, fenômeno) que não quer dizer só o acontecimento, mas o acontecimento apropriador, aquele que resulta do encontro entre a verdade buscada e aquela que se mostra como evento.

$\mathrm{O}$ fato fica isolado no contexto de Heidegger porque o fato é reducionista, é particular. São fatos isolados que, muito embora sejam sociais, não tem o alcance do conhecimento no seu encontro com o Dasein. 


\section{Capítulo IV - Humanismo em Heidegger}

\section{a) Liberdade}

O tema é longo e complexo, apresentando numerosas e variáveis definições ao longo da história do pensamento que, na grande maioria, relacionam liberdade com autodeterminação.

Heidegger, também aqui, segue a via da análise fenomenológica que leva a ideia de que a liberdade não é algo objetivo, ou seja, melhor perguntar que é ou que não é liberdade, e não tanto se alguém é livre ou não.

Esta liberdade de aspecto mais existencial, cujas raízes alcançam o pensamento de Jaspers, apresenta noção de liberdade não tanto referente a conflito entre a vontade subjetiva e um imperativo objetivo, mas se relaciona mais com o determinante e o próprio ato de escolher em obedecer.

O Dasein se comete na liberdade e é essencial e necessariamente livre, ou melhor, está condenado a ser livre, como ser lançado de si segundo as suas possibilidades.

O Dasein transcende para o mundo pela liberdade de possibilidade e pela limitação que lhe marca.

Assim, a liberdade é para o sair de si e ir em busca do e pelo Dasein.

Não se trata de ser somente uma liberdade de algo (liberdade negativa, o que é sem sentido por si só), ou somente de uma liberdade para algo (liberdade positiva), mas de uma liberdade que se faz, como fundamentação do enraizamento no mundo, condicionando-o em seus limites e que retorna relacionada a uma fundamentação não fundamentada do Dasein para a qual Heidegger utilizará da palavra Abgrund (abismo, precipício, despenhadeiro). ${ }^{119}$

${ }^{119}$ Grund traduz por terra, solo; a terra a partir da qual se constrói. Portanto, o fundo do conceito, o cerne. 
A liberdade é o fundamento do fundamento, ou seja, o mais profundo do fundamentar é um não fundamento.

"A liberdade, por ser o fundo deste F., também é o abismo (sem fundo) do seraí. Não que seja infundado o relacionamento individual e livre, mas no sentido de que a liberdade, em sua natureza essencial de transcendência, põe o ser-aí, como poder-ser em possibilidades que se estendem diante de sua escolha finita, ou seja, em seu destino". ${ }^{120}$

\section{b) Verdade}

Esta é noção mais discutida que a anterior, porque, diferentemente daquela, se apresenta como sendo um dos objetos fundamentais da discussão filosófica presente desde o seu início.

Para os leigos, verdade se traduz como aquilo que corresponde com exatidão a realidade.

$\mathrm{Na}$ filosofia, Nicola Abbagnano apresenta que são cinco conceitos que podem ser elencados como aqueles fundamentais.

"É possível distinguir cinco conceitos fundamentais de V.: 1- como correspondência; 2- como revelação; 3- como conformidade a uma regra; 4- a V. como coerência; 5- a V. como utilidade. Essas concepções têm importâncias diferentes na história da filosofia: as duas primeiras, em especial a primeira, sem dúvida são as mais difundidas. Não são nem mesmo alternativas entre si: é possível encontrar mais de uma no mesmo filósofo, embora usadas com propósito diferente. No entanto, por serem díspares e mutuamente irredutíveis, devem ser consideradas distintas." 121

Independentemente dos conceitos apresentados, a verdade em Heidegger se encaixa como uma das formas presente no segundo conceito.

\footnotetext{
${ }^{120}$ Nicola Abbagnano, Dicionário de filosofia, verbete.

${ }^{121}$ Ibidem, verbete.
} 
Também neste ponto, Heidegger parte do pensamento de Husserl que postula a noção de verdade em afinidade com outra, a da adequação, apontando no sentido de na verdade haver correspondência entre o que se tenta significar e o significado, o que, não sendo fundamentalmente baseado na experiência, se traduz por uma relação essencial.

"Por conseguinte, teríamos que definir a verdade segundo 2. e 4. como ideia de adequação, ou ainda, como a correção do posicionamento e da significação objetivantes." 122

Em Heidegger, a verdade é transformada em um elemento da existência, que descobre o ser em seu existir autêntico (autenticidade) e o encobre em seu existir inautêntico (inautenticidade).

Assim, Heidegger recusa que a verdade possa ser entendida como adequação entre o intelecto e o ente e explicita o verdadeiro significado de verdade: desvelamento, que remonta ao termo primitivo que no início da filosofia, na antiguidade pré-clássica.

Se a verdade é desvelamento, ela somente pode acontecer naquele ente que está no mundo, situação exclusiva e própria do Dasein, que a constitue.

Desvelar e velar é estar no mundo em situação e o Dasein é tanto a verdade, como a não verdade, porque esta última não significa falsa ou errada, mas tão somente que permanece encoberta.

Desvelamento é aletheia (no sentido de não esquecido ou não escondido) que quer transmitir verdade, veracidade, mas também honestidade e sinceridade, superando a noção que Heidegger inicialmente apresenta quando mais jovem mais ligada a adequação de influência de Husserl.

A verdade exige explicitamente o encobrimento para a possibilidade de se retirar do encobrimento, desocultar, descobrir. Eis o objetivo da filosofia fundamental: perceber o velamento do ser e desvelar o ente e o sentido do ser.

Tudo no sentido da frase conhecida: "são violetas, são pequeninas e estavam escondidas, mas nós a descobrimos".

${ }^{122}$ Edmund Husserl, Investigações lógicas, in Os Pensadores, p. 94. 
Desta forma, a verdade é um aspecto da realidade e não está limitada a afirmações teóricas absolutas como apresentam as convicções e as representações.

Este é o erro funesto de Platão que no Mito da Caverna relacionou a verdade com a luz do Sol e a aparência (não verdade, negação da verdade) com o escuro do fundo da caverna.

Ao aprender que a verdade está na luz somente, perde-se também a noção da realidade do desvelamento, o que fará que a verdade seja cada vez mais conduzida ao significado de adequação e a representação adequada na relação sujeito e objeto que Descates apresenta.

Ao contrário, seja na luz, seja no escuro, a realidade é sempre do ser.

Enfim, a verdade é des+coberta porque e quando o Dasein se revela a si mesmo como próprio que é.

"La verdad entendida en el sentido más original es algo inherente a la estructura fundamental del 'ser ahí'. El término significa um existenciario. Pero con esto queda trazada la respuesta a la cuestón de la forma de ser de la verdad y del sentido de la necesidad del supuesto de que 'hay uma verdad", 123

\section{c) Direito}

No mundo do direito (como também em outros campos do estudo), o que gera o convencimento: a veracidade da palavra dita ou a autoridade da fonte que a disse?

A situação é sensível porque, dependendo da sua resposta, pode ocasionar ou não a desistência de uma elaboração original de pensar e conduzir a atitude, porque alguns podem simplesmente desistir ou se impor limites porque vai contra a opinião de determinado autor a quem já se deu o título de autoridade no assunto.

${ }^{123}$ Ser e tempo, Fondo de Cultura Económica, p. 247. 
E só quem rompe com este preconceito cultiva a trilha da verdade que aceita e dialoga com o diferente, com o adverso.

Neste ponto, vale ressaltar, mesmo que de forma parcial, o importante papel exercido pelos meios de comunicação de massa, movidos pelo seu imperioso desenvolvimento tecnológico, que atua na formação e no zelo desta cultura da autoridade que a sociedade vive, no qual o Poder Judiciário, mais que distribuir justiça, trabalha com caráter empresarial de metas a serem cumpridas, fazendo do juiz não mais um julgador de conflitos sociais, mas um gerente-empresário.

Jeannette Antonios Maman dera o alerta há tempos que a origem do autoritarismo jurídico está no nosso processo de colonização que sofremos.

"Com a colonização econômica e política efetuou-se a dominação pelas idéias". 124

Se o discurso jurídico é articular, a palavra é expressão do seu ser e a linguagem é a casa deste ser, uma vez que a experiência mora na palavra.

O pensamento é a busca da verdade que aceita esta unidade e variedade. Mais do que dizer, a palavra acompanha uma realidade.

A palavra (entendida agora como significante) é simples veículo de transmissão, é incompleta e não atinge a realidade do ser; é só lógica.

Já a palavra (então como casa do ser, denominada $\log { }^{125}$ ) é expressão do ser, é onde ele tem o seu abrigo e guarida. Entendê-la é entender o desvelar e o velar do ser.

A autoridade é o que causa império e domínio, deslocando a fonte da verdade do ente para o poder da sua fonte.

Não interessa a palavra, mas sua origem.

\footnotetext{
${ }^{124}$ Jeannette Antonios Maman, Fenomenologia existencial do direito, p. 62.

${ }^{125} \mathrm{O}$ logos atua como o arauto: anuncia quem ainda não apareceu, mas que já está aqui, presente, prestes a ser desvelado.
} 
Ocorre, assim, uma sistemática perda de conteúdo, primeiramente reduzindo o próprio ser ao seu lógico.

Depois, se reduziu o lógico à subjetividade de uma linguagem e, hoje, se desvincula a linguagem da sua realidade.

A palavra, perdendo o seu ser, vale relativamente à sua prática, sendo compensada pelo poder de uma autoridade.

No mundo do autoritarismo, a palavra não é mais reveladora (é opressora).

O primeiro aspecto que a palavra revela é a que só existe com a reflexão do ser-com mundano, na relação da totalidade dos entes. E é possível se atingir aquilo que se chama aletheia?

O artista nos coloca claramente que sim, mas não de uma forma perceptiva que se baseia no ôntico.

$\mathrm{O}$ artista nos ensina que a relação se faz muito mais pela inspiração, noção que leva a conhecer com base no ontos, fazendo lembrar o que está frente do próprio ser.

A manipulação pelo autoritarismo acontece quando fazem com que a palavra perca seu conteúdo de ser-com, o que típico da sociedade moderna possuidora de um avanço científico-tecnológico desumano que cria fetiches e faz com que o homem perca sua relação com o ser-com-o-outro-no-mundo.

A palavra perde para que a sociedade moderna possa subsistir ${ }^{126}$, pois ela se funda na fácil manipulação lógica, preferindo, assim, a incerteza, a insegurança e o conseqüente autoritarismo. A aceitação de conceitos vem junto com a aceitação de palavras.

Poderia surgir, então, um clima de pessimismo que fortalece a noção de que tudo o que se reflete é em vão.

${ }^{126}$ As ideias dominantes são as ideias de uma classe social dominante que as impõe como importantes. 
O Dasein é assombro diante da necessidade de uma nova consciência reeducadora que, de igual modo, também investiga a fecundidade do logos jurídico.

A base existencial do direito é o seu logos, entendida como palavra que revela, que, como no seu sentido grego, põe no caminho ao encontro de algo.

"É a linguagem que fala, não, ou não primordialmente, o homem". 127

Falar o logos é deixar desvelar e velar e não só oralidade, como Heidegger ensina em Ser e Tempo. Falar com o logos é a capacidade de compreensão pela descoberta.

Mas isto não serve se os discursos jurídicos são fundados não no refletir, mas no simples se apropriar da opinião de uma autoridade (ou reconhecida como tal), constituída e legitimada pelo procedimento retórico com alicerce na argumentação de falácias inconsistentes na vida existencial do ente.

Se a linguagem é a morada do ser, é a palavra (logos) que fala. O homem é apenas um ouvinte, onde, numa relação de audição, tenta escutar a voz do Dasein.

Percebe-se, então, que nesta relação de audição, o homem é provocado a ouvir a voz do ser (no caso, do ser jurídico), mas não como ente passivo (como acontece no autoritarismo), mas numa relação de responsabilidade típica do ser-com-o-outro.

Assim, o logos jurídico assombra o operador: por que o direito é o que é e não outra coisa?

Heidegger propõe, para alcançar (num diálogo fraterno) o logos na sua verdade, voltar ao berço anterior a Sócrates para que o homem possa ser capaz de entender e desconstruir a herança metafísica como ela se apresentou nestes dois milênios com as seduções que a técnica apresenta, certo de que tudo culminou e favoreceu o surgimento e crescimento de um humanismo egocêntrico e, com ele, renunciar a sua lógica.

Realizando este caminho, se descobre que palavras e linguagem não são meros invólucros nos quais os entes são empacotados para o comércio daqueles que escrevem e falam.

${ }^{127}$ George Steiner, As idéias de heidegger, p. 26. 
É, em palavras e linguagem, que as coisas nascem e são. Afirmar que o ente é, é o mesmo que afirmar a sua existência porque falar o ser da coisa somente a linguagem pode e deve falar.

O Dasein se encontra na linguagem e é, em sua essência profunda, falante: eis sua virtude e miséria. $O$ ente vive essencialmente na e através da linguagem, entendida na contextura existencial da experiência cotidiana.

Diante da miséria atual do direito, é bom caminho a reflexão sobre sua essencialidade, que poderá permitir o retorno a sua autenticidade.

Ao longo da sua formação, o pensamento moderno e metafísico persiste em trabalhar nos conceitos ${ }^{128}$.

No entanto, se o jurídico pede uma nova consciência, estes devam talvez, não serem esquecidos ou abandonados, mas um sistema que seja funcional, reconhecendo que aí está o seu ser.

O direito não pode ser reduzido ao conhecimento de um conjunto de técnicas ou ao resultado de técnicas.

Aproximando-se do social, também no direito, o conhecimento deve ser entendido por compreensão do fenômeno jurídico na revelação e ocultação porque o direito é o real e o histórico.

Definir o direito sem se levar em conta o que ele é no mundo é totalmente errôneo e falso. Conhecer o direito e seus caminhos é compreender o fenômeno jurídico. Repita-se: o direito faz parte do mundo e não existe fora dele.

“A parir da existência humana (o homem existencial), é possível pôr o problema de uma concepção ontológico-existencial do mundo com consequências para o direito. (...) Nós somos englobados no mundo: (...) É na realidade englobante - realidade social, econômica e política - situação histórica concreta, que o homem existe como Dasein."129

\footnotetext{
${ }^{128}$ Sócrates pode ser considerado o apóstolo da razão e o fundador do saber conceitual.

${ }^{129}$ Jeannette Antonios Maman, Fenomenologia existencial do direito, p. 52.
} 
A dificuldade em entender a ontologia de Heidegger somente após o entendimento do ser-no-mundo como estrutura fundamental do Dasein é que descortina a compreensão da espacialidade existencial do Dasein. Como no fenômeno e no acontecimento, o mesmo ocorre no direito.

O saber já é uma espécie de ser e não ser um salto incompreensível do sujeito para o objeto e vice-versa. Noutro sentido, saber é uma forma de ser-com, com e dentro do mundo que o circunda.

"O mundo vem ao nosso encontro (...) na forma de coisas. Mas das obviamente inumeráveis entidades-objetos que Dasein encontra, aquelas que constituirão o seu ser-no-mundo não são quaisquer coisas. São os que os gregos chamaram pragmata, 'quer dizer aquilo com que temos de lidar em nossas atividades de interesse'. A palavra de Heidegger para pragmata é Zeug, a qual, por sua vez, tem sido traduzida como 'equipamento', 'instrumentação', outllage. O seu principal derivativo alemão é Werkzeug, que significa 'ferramenta'. A distinção entre 'qualquer coisa' e Zeug é essencial para a Weltanschauung (visão do mundo)heidegerriana. Vorhandenheit, que significa 'presença-próxima', é o caráter do objeto 'aí'. Caracteriza a matéria da especulação teórica, de estudo científico. Assim, a 'natureza' é vorhanden para o físico, e as rochas são vorhanden para o geólogo. Mas, não é assim como um pedreiro ou um escultor recebe uma rocha. A sua relação com a pedra, a relação crucial para o seu Dasein, é a de Zuhandenheit, de uma 'acessibilidade imediata'. Aquilo que é zuhanden, literalmente, 'em mão', revela-se a Dasein, é recebido e absorvido por Dasein, de modos absolutamente constitutivos do ‘aí' em que a nossa existência foi lançada e no qual deve realizar o seu ser",

Colocar o ente como especulação teórica de um estudo científico é tê-lo próximo, só isso. Ter as partes e o litígio de um processo como coisas que deverão ser fruto de um estudo e de uma decisão é, então, dispensável.

Diferente é a posição da linguagem para o poeta que se debruça e trabalha não uma "coisa" de forma puramente racional. De forma diferente, o artista encara

${ }^{130}$ George Steiner, As idéias de heidegger, p. 77-78. 
e envolve entes que são como instrumentos de sua paixão (e que verdadeiramente o são). Assim é, por exemplo, o poeta diante do papel, do lápis, da visão, dos sentimentos...

O compositor (que é um artista) disse sobre o poder da criação:

"Não, ninguém faz samba só porque prefere, força nenhuma no mundo interfere, sobre o poder da criação (...) chega a nos angustiar. E o poeta se deixa levar por esta magia (...)"131.

Quando se fecha o direito para seu uso, se fecha para a acessibilidade imediata do direito. Olhar apenas teoricamente para o direito é ser cego, ou melhor, ter a vista tapada por uma venda. Contudo, quando se assenta com ele, se descobre sua utilidade-fim, é extensão da mão, assim como o pincel ou o formão nas mãos do artista: não é mero instrumento, pois a visão é a de circunspecção, ponderada para um fim específico e atual, e a teórica.

O direito não pode se fechar ao seu redor. Ao contrário:

"Uma ordem jurídica verdadeira procura aproximar o extraordinário (o autêntico) do cotidiano (o inautêntico)"132.

Isto não se adapta a uma realidade do jurídico tido como empresa que deve atingir metas e trabalha com as partes como se clientes fossem.

Diante desta atual vivência inautência do direito, diante do atual "batepapo" cotidiano jurisdicional (sentenças e acórdãos se tornaram realmente isto) onde se solucionam litígios sem a real intenção de fazer justiça, mas tão somente pronunciar decisões (mesmo que predeterminadas) que "resolvam"litígios, muitas vezes mais baseados em doxas que em verdades, o jurista deve ao menos poder se esforçar por retornar ao direito autêntico, motivados por uma preocupante inquietação.

$\mathrm{Na}$ atualidade (porque fora do seu tempo, a existência não pode ser entendida ${ }^{133}$ ), o direito se esqueceu do necessário cuidado. Porém, isto está longe de ser entendido como uma falha ou um erro, pois é na inquietante consciência de estar na

${ }^{131}$ Samba $O$ poder da criação - samba do trabalhador de João Nogueira.

132 Jeannette Antonios Maman, Fenomenologia existencial do direito, p. 77.

${ }^{133}$ Neste sentido é o título da grande obra de Heidegger: Ser e Tempo, ou seja, ser é tempo. 
condição fundamental da inautenticidade, como que caindo em si, que surge a angustiante oportunidade de buscar a autenticidade: ser ser-com e ser-para.

E ser-com e ser-para é toda a humanidade, nela compreendido também o seu meio ambiente, todo o mundo em que habita.

Para Jeannette Antonios Maman o Direito é encarado como expressão da situação existencial, onde expressão é entendida como manifestação, como revelar-se, mostrar-se tal como é e existe na situação.

Na situação que se encontra, o homem moderno tecnológico é alienado e precário, escravo do consumo de massa, munido (mas não satisfeito) pelo conhecimento metafísico-científico de ver e compreender o mundo.

Mas o homem descobre que na sua situação existencial limite do ser resoluto possui a capacidade de tomar em suas mãos o destino de sua vida e superar a situação. Este é o Dasein: viver a co-existência como essência do autêntico.

Heidegger não é contra a técnica e a tecnologia.Ele não é um tecnofóbico, como tantos afirmam, capaz de dar a técnica e a tecnologia uma nocividade intrínseca, nem defende um retorno a uma arcaica arte.

Ele nos alerta quanto a má aplicação da técnica e da tecnologia, típicas da modernidade sem a modernização.

Heidegger é contra o alto preço que se paga pela exploração racional da técnica, reduzindo os entes a objetos apartados da sua autenticidade.

A técnica jurídica torna-se um pesadelo que escraviza o seu senhor. A razão técnica-instrumental faz do outro um instrumento, banalizando-o a uma coisa. Aí acontece a apropriação da existência do ser.

O significado original da técnica foi ofendido. Originalmente techne era tida como o artista fazia o seu trabalho: não como um profissional descompromissado, mas arte com técnica (ou seja, habilidade), num reconhecimento das verdadeiras finalidades, descobrindo o que a argila se permite fazer.

A verdadeira técnica impõe não tão só um uso, mas um adequado conhecimento artístico, partindo de um reconhecer do homem a sua vocação humana. 
Mas perceber a condição inautêntica (refletida em maior clareza hoje na ecologia e na política) do direito não é ser pessimista. É compreender que é possível a busca do resgate da autenticidade. 


\section{Capítulo V - Crítica de Heidegger à doutrina de Platão sobre a verdade}

A interpretação de Heidegger sobre a Apologia da Caverna (ou Mito da Caverna) tende a nos fazer considerar a re-construção do compreender e interpretar Platão, quanto à chamada "teoria das ideias".

A tradução da Professora Doutora Jeannette Antonios Maman foi a primeira na língua portuguesa, publicada no âmbito da Academia apenas para estudos de pós-graduação. Para o vocabulário grego, contou com a ajuda do Me. Pedro Proscurcin Júnior, seu orientando.

"A doutina de Platão sobre a Verdade" seria posteriormente traduzida no conjunto da obra de Heidegger pela Editora Vozes.

Segue o texto para posteriores abordagens. 


\section{MARTIN HEIDEGGER ${ }^{134}$}

\section{A DOUTRINA DE PLATÃO SOBRE A VERDADE ${ }^{135}$}

$[203]^{136} \mathrm{O}$ saber das ciências é usualmente enunciado sob a forma de proposições e oferecido como conjunto de resultados compreensíveis, os quais desde logo podem ser utilizados. Todavia, a "doutrina" de um pensador é o que sobra implícito dentro do que é expressamente dito, aquilo ao que o homem está aberto, "exposto", de tal sorte que podemos dispor ${ }^{137}$ sem pensar.

A fim de experimentar e conhecer, doravante, o que um pensador deixou implícito $^{138}$, qualquer coisa que possa ser, nós temos que considerar o que ele disse. Para satisfazer adequadamente esta exigência, seria necessário examinar todos os "diálogos" de Platão na sua relação mútua. Uma vez que isso é impossível, nós poderemos permitir que um caminho diferente nos guie para o implícito no pensamento de Platão.

O que permanece implícito no pensamento de Platão é uma mudança na determinação da essência da verdade. O fato que essa mudança ocorra, em que isto consiste, e o que lhe serve de fundamento: é isto que nós desejamos esclarecer ${ }^{139}$ numa interpretação da "alegoria da caverna".

A "alegoria da caverna" é apresentada no começo do livro sétimo do "diálogo" sobre a essência da po/lij [pólis] (República, VII, 514 a, 2 até 517 a, 7). A "alegoria" $" 140$ narra uma estória. A narrativa desdobra-se na conversação entre Sócrates e Glauco. Sócrates narra a história, Glauco revela um crescente assombro. A tradução que

\footnotetext{
${ }^{134}$ HEIDEGGER, Martin. Wegmarken. Frankfurt am Main: Vittorio Klostermann, 1976, pp. 203-238.

135 "Plato's doctrine of truth" (PLATONS LEHRE VON DER WAHRHEIT): traduçãoeminglêspor Thomas Sheehan, in: Pathmarks, ed. William Mcneill, Cambridge (GB) e Nova York: (C Cambridge University Press, 1998, pp. 155-182; "La doctrine de Platonsurlavérité": tradução do francêspor André Préau para () ÉditionGallimard, 1968, Questions I et II, pp. 423-469. Tradução para o português de JeannetteAntoniosMaman.

136 Os números de páginas em colchetes se referem às páginas em Wegmarken, Gesamtausgabe, Band 9. Nessa edição, as páginas 204, 206, 208, 210 e 212 contêm o texto grego da Alegoria da Caverna, o qual não é apresentado aqui.

${ }^{137}$ Dispor como utilizar, utilizar deste saber sem pensar.

${ }^{138}$ Em inglês: "unsaid" (não dito; implícito); em francês: " $n$ 'a pasdit" ou "informulê" (não dito; implícito).

${ }^{139}$ Esclarecer no sentido de "jogar luz", não no sentido do esclarecimento iluminista.

${ }^{140}$ Em alemão: "Gleichnis" (alegoria, parábola).
} 
nós juntamos ao texto compreende passagens explicativas estranhas ao original ${ }^{141}$ e que nós colocamos em parênteses. [fim 203]

[205] "Imagine isso: Pessoas vivem abaixo da terra numa habitação em forma de caverna. Estendendo-se a uma grande distância ao alto, próximo a luz do dia, está sua entrada, para a qual a caverna inteira agrupa-se. As pessoas estão nesta morada desde a infância, acorrentados pelas pernas e nuca. Este é o motivo, também, de elas permanecerem no mesmo lugar, de tal modo que a única coisa para elas olharem é tudo quanto elas encontrarem frente suas faces. Mas porque estão acorrentadas, elas são incapazes de mover suas cabeças ao redor. Alguma luz, por certo, é possibilitada a elas, a saber, de um fogo que emite seu brilho em direção e por detrás delas, estando acima e a alguma distância. Entre o fogo e aqueles que estão acorrentados (portanto, atrás de suas costas), nesse lugar estende-se um caminho, em uma dada altura. Imagine que um muro baixo foi construído ao longo da extensão desse caminho, como a cortina baixa que os titereiros levantam, sobre a qual eles mostram seus marionetes."

"Eu vejo", ele [Glauco] disse.

"Então, agora, imagine, ao longo deste muro baixo, que pessoas estão carregando toda espécie de coisas que passam acima da parede: estatuetas e outras esculturas feitas de pedra ou madeira e muitos outros artefatos que as pessoas fizeram. Como você pode esperar, alguns (dos carregadores) estão conversando entre si (enquanto eles vão andando) e alguns estão em silêncio.

[Glauco:] "Este é um quadro incomum que você está apresentando aqui, e estes são prisioneiros incomuns".

"Eles são muito parecidos com nós humanos" - eu respondi. "O que você acha? Desde o princípio, tal espécie de homens nunca se orientou, seja por iniciativa própria, seja com a ajuda dos outros, a ver qualquer coisa que não fosse as sombras que o brilho do fogo (constantemente) projeta sobre a parede em frente deles".

${ }^{141}$ Ao original grego de Platão. 
[Glauco:] "Como pode ser diferente", ele disse, "uma vez que eles são forçados a manter suas cabeças imóveis por toda suas vidas?”

[207] "E o que eles veem das coisas que estão sendo transportadas (a suas costas)? Não é apenas isso que eles veem (isto é, as sombras)?”

[Glauco:] "Certamente".

"Agora, se eles fossem capazes de dizer alguma coisa sobre o que viram e pudessem discutir sobre isso, não acha que eles poderiam considerar o que eles veem na parede como entes?"

[Glauco:] "Eles teriam que considerar".

"E se agora, esta prisão, também tivesse um eco reverberando da parede que eles têm em frente (a parede que olham exclusiva e constantemente)? Assim que um daqueles que andam por trás das pessoas acorrentadas (e transportando coisas) fizesse um barulho, acha que os prisioneiros imaginariam que o que fala seria qualquer outro que não a sombra que passa em frente deles?"

[Glauco:] "Nada mais, por Zeus! ${ }^{142}$

"De nenhuma maneira, então", eu respondi, "teriam aqueles que estão acorrentados dessa forma alguma vez considerado algo a ser descoberto exceto as sombras lançadas pelos objetos".

"Isto absolutamente teria de ser o caso", ele [Glauco]disse.

"Então agora," eu repliquei, "observe o processo por meio do qual os prisioneiros são liberados de suas correntes e, juntamente com isto, curados da falta de discernimento $^{143}$. Além disso, considere que tipo de falta de discernimento teria que ser se o seguinte ocorresse com aqueles que estivessem acorrentados. Quando qualquer um deles fosse desacorrentado e forçado, de repente, a levantar-se, a girar-se ${ }^{144}$, a andar e a levantar os olhos para luz, em cada caso a pessoa seria capaz de fazer isso unicamente sentindo dor; e, por causa do vibrante brilho, ele não seria capaz de olhar aquelas coisas cujas sombras

${ }^{142} \mathrm{O}$ grego " $\mu \alpha \backslash \Delta \mathrm{l} / \mathrm{ov \chi}$ e) /gwg / $\varepsilon^{\prime} \varphi \eta$ ” mais literalmente significa “"Por Zeus, Eu não', ele disse". (Existem mais que numerosas formas em que alguém possa expressar concordância em um diálogo platônico). [Nota do tradutor].

${ }^{143}$ Einsichtlosigkeit: a) $\varphi \rho 0 v v \eta$. [Nota do tradutor].

${ }^{144}$ Literalmente: girar ao redor o pescoço [denHalsumzuwenden, $\pi \varepsilon \rho 1 \alpha \gamma \varepsilon$ iv $\tau o$ ไn $\left.\alpha v \xi a ́ \alpha\right]$. [Nota do tradutor]. 
via antes. (Se tudo isto acontecesse com o prisioneiro), o que você acha que ele diria se alguém o informasse que o que ele viu antes eram (apenas) ninharias, mas que agora ele estava um pouco mais próximo dos entes; e que ele também viu mais corretamente como uma consequência do agora estar voltado para o que é mais entitativo ${ }^{145}$ ? E se alguém (então) lhe mostrasse cada uma das coisas que vão passando e lhe forçasse a responder a pergunta sobre o que se trata, [209] não acha que ele ficaria sem saber o que fazer e, além do mais, também consideraria que o que ele viu antes (com seus próprios olhos) está mais desoculto do que o que está agora sendo mostrado (para ele por algum outro)?”

"Sim, absolutamente", ele disse.

"E se alguém ainda o forçasse a examinar o brilho do fogo, não machucaria os seus olhos e ele, então, não se desviaria e fugiria (de volta) para o que ele é capaz de olhar? E ele não decidiria que (o que ele podia ver antes sem qualquer ajuda) é, de fato, mais claro do que o que agora está lhe sendo mostrado?"

"Precisamente", ele disse.

“Agora, entretanto, se alguém, usando a força, arrancasse ele (que foi liberto das correntes) para fora dali e o erguesse pela íngreme e difícil encosta e não lhe permitisse se livrar até que o tivesse arrastado para fora a luz do sol, esse que foi arrastado desta forma não sentiria, neste processo, dor e raiva? E, quando estivesse alcançado à luz solar, os seus olhos não seriam preenchidos com o brilho, por conseguinte, ele não se sentiria incapaz de ver algo do que agora é revelado como o desoculto ${ }^{146}$ ?"

"Ele seria totalmente incapaz de fazer isso", ele disse, "ao menos não de repente".

"Obviamente, levaria algum tempo se acostumar, eu acho, se isso é uma questão de compreender com os olhos de alguém, com o que está ali em cima (fora da caverna a luz do sol). E (nesse processo de se acostumar) poderia, primeiro e mais facilmente, estar apto a olhar as sombras e, depois, as imagens das pessoas e de outras coisas, enquanto elas são refletidas na água. Mais tarde, entretanto, ele estaria apto a ver as coisas a si mesmas (os entes, em vez dos seus reflexos obscuros). Mas dentro do alcance de tais coisas, poderia ser mais fácil para ele contemplar tudo o que exista na abóbada celeste,

\footnotetext{
${ }^{145}$ Em inglês: "in being".

${ }^{146}$ Em inglês: "unhidden" (desoculto; desencoberto). Em alemão: "Unverborgene".
} 
e a própria abóbada, ao fazê-lo à noite, ao olhar a luz das estrelas e a lua, (mais facilmente, deve-se dizer) do que ao olhar para o sol e seu brilho durante o dia."

[Glauco:] "Indubitavelmente".

[211] "Porém, eu penso que, finalmente, ele estaria na condição de olhar o próprio sol, não apenas ao seu reflexo, quer seja na água ou onde quer que possa aparecer, mas ao sol mesmo, tal como ele é e a si mesmo, e no lugar apropriado para ele, e contemplar de que natureza ele é”.

"Isso necessariamente aconteceria desta forma", ele disse.

"E tendo feito tudo aquilo, a esse tempo ele também seria capaz de congregar o seguinte sobre isso (o sol): que ele é o que confere as estações do ano e os anos, e que determina tudo o que existe na (agora) região visível (da luz solar), e, ademais, que isso (o sol) também é a causa ${ }^{147}$ de todas aquelas coisas que as pessoas (que habitam abaixo na caverna) têm, em certa maneira, ante seus olhos."

"Isso é óbvio", ele disse, "que ele chegaria a estes (o sol e tudo o que é posto em sua luz), depois de ele ter deixado mais longe aqueles (que são meramente reflexos e sombras)".

"E então o que? Se ele novamente recordasse de sua primeira morada, e o "saber" que transita como regra ali, e as pessoas com quem ele estava acorrentado ${ }^{148}$, não acha que ele se consideraria com sorte por causa da transformação (que teria acontecido), e, por contraste, se sentiria triste por eles?"

[Glauco:] "Muito por certo".

"Entretanto, se (entre as pessoas) no lugar anterior de habitação (isto é, a caverna) se estabelecessem certas honras e louvores para quem quer que mais nitidamente olhasse o que passasse por lá (i. e., coisas que acontecem todos os dias) e, ademais, melhor se lembrasse qual normalmente vem primeiro, qual por último, qual vem ao mesmo tempo, e, para quem quer que (então) pudesse mais facilmente predizer, o que fosse ocorrer em seguida - você não acha que ele (que saído da caverna) invejaria (ainda agora) aqueles (na caverna) e desejaria competir com aqueles (ali) que são estimados e têm poder? Ou ele não escolheria desejar sobre si a condição que Homero fala: "viver sobre a terra (acima da

\footnotetext{
${ }^{147}$ Em alemão: "Ursache” (tradução contextual do termo grego ai!tioj que significa causador).

148 Literalmente: "aqueles que estavam acorrentados com ele então (naquela altura)" [der damalsmitihmGefesselten/tw=n to/te sundesmwtw=n]”. [Nota do tradutor].
} 
terra) como um [213] criado pago de um outro lavrador privado de recursos" $" 149$. E ele não preferiria acolher absolutamente qualquer outra coisa, do que associar-se com aquelas opiniões (sustentadas na caverna) e ser aquele tipo de ser humano?"

"Eu acho", ele disse, "que preferiria suportar tudo do que ser aquele tipo de ser humano (o tipo da caverna-habitação)."

"E agora”, eu respondi, "considere isto: Se esta pessoa que havia saído da caverna voltasse lá pra baixo de novo e sentasse no mesmo local como antes, ele não encontraria neste caso, uma vez tirado tão de repente da luz solar, seus olhos antecipadamente preenchidos com a escuridão?"

"Sim, muito por certo", disse ele.

"Se ele agora, mais uma vez, tivesse que se ocupar com aqueles que permaneceram acorrentados, afirmando e sustentando opiniões sobre as sombras enquanto seus olhos estão ainda debilitados e antes de terem sido acostumados, um ajuste que demandaria um pouco de tempo - ele não seria então exposto ao ridículo ali em baixo? E eles não o fariam saber que, sim, ele havia subido, mas somente a fim de voltar (dentro da caverna) com seus olhos estragados, e então, certamente, não valeria a pena subir? E se eles pudessem agarrar esta pessoa que se encarregou de libertá-los das correntes e conduzilos acima, e se eles pudessem o matar, eles realmente não o matariam?"

"Eles certamente que fariam", ele disse.

O que significa esta história? Platão mesmo oferece a resposta: ele tem imediatamente a interpretação seguindo a estória (517 a, 8 até 518 d, 7).

A residência cavernária é a "imagem"150 parath $\backslash n . .$. di)o)/yewjfainome/nhn e(/dran“o lugar da nossa residência, o qual (de modo cotidiano) é revelado para visão enquanto olhamos ao redor". O fogo na caverna, que queima sobre os que habitam ali, é a "imagem" para o sol. A abóbada da caverna representa a abóbada do

${ }^{149}$ Odisséia XI (489-490). Versos incluídos no lamento proferido pela sombra de Aquiles, no momento que Ulisses o congratula por manter-se rei no Hades.

${ }^{150}$ Em alemão: "Bild". 
céu. As pessoas vivem abaixo desta abóbada, consignados a terra e a ela sujeitos. O que lhes circunda e concerne ali [214] é, para eles, "o real" ["das Wirkliche"], isto é, oque aquilo é. Nesta morada do tipo-caverna eles sentem que estão "no mundo" e "em casa" e aqui eles encontram o que podem confiar.

Por outro lado, as coisas que a "alegoria" menciona, como visíveis fora da caverna, são a imagem para o que propriamente o ente dos entes ["das eigentlichSeiendedesSeienden"] consiste. Isso, de acordo com Platão, é o que por meio do qual os entes aparecem em sua "forma visível". Platão não considera esta "forma visível" como um mero "aspecto". Para ele, a "forma visível" tem, ademais, alguma coisa de um "adiantar-se", mediante o qual uma coisa se "apresenta"151. Situando-se nesta "forma visível" o ente mesmo mostra a si mesmo. Em Grego "forma visível" é $\varepsilon \imath \delta o \zeta$ ou $1 \delta \varepsilon \alpha$. Na "alegoria", as coisas que são visíveis à luz do dia fora da caverna, onde a visão é livre para olhar tudo, são uma ilustração concreta das "ideias""152. De acordo com Platão, se as pessoas não tivessem essas "ideias" em vista, quer dizer, a respectiva "aparência" das coisas - seres vivos, humanos, números, deuses - eles jamais poderiam perceber isto ou aquilo como uma casa, como uma árvore e como um deus. Eles habitualmente acreditam que vêem diretamente esta casa e aquela árvore e o mesmo com cada ente. Geralmente eles nunca suspeitam que é sempre e apenas na luz das "ideias" que eles veem tudo que passa tão facilmente e familiarmente por "real". Segundo Platão, o que eles presumem ser exclusivamente e propriamente o real - o que eles imediatamente veem, ouvem, apreendem, calculam - sempre permanecerá uma mera sombreação da ideia e, consequentemente, uma sombra. Aquilo que está mais próximo, ainda que tendo a consistência de sombras, mantém os humanos dia a dia prisioneiros. Eles vivem em uma prisão e deixam todas as "ideias" para trás de si. E, uma vez que não reconhecem de forma alguma esta prisão pelo que ela é, eles consideram que este território cotidiano, abaixo da abóbada dos céus, é a arena da experiência e do julgamento que oferece o único critério para todas as coisas e relações e que fixa as únicas regras para sua disposição e arranjo. [215]

Agora se os seres humanos, considerados nos termos da "alegoria", repentinamente, enquanto ainda estiverem na caverna, de novo lançarem os olhos ao fogo,

\footnotetext{
${ }^{151}$ Nota de Heidegger no "Geistige Überlieferung”, edição 1942: 'Ser presente-para (Beingpresent-to), isto é, presente-até (present-unto) [An-, d.h. herzu-wesen]".

152 Em alemão: "Ideen".
} 
cujo brilho produz as sombras das coisas que são carregadas de um lado para o outro, eles imediatamente experimentariam este desacostumado giro ao redor de seu olhar fixo como uma ruptura do comportamento habitual e da opinião corrente. De fato, a mera sugestão de tão estranha instância, a ser adotada, enquanto ainda no interior da caverna, é rejeitada, visto que ali, na caverna, se está na clara e completa posse do real. As pessoas na caverna são tão apaixonadamente atadas a sua "visão", que elas são incapazes de mesmo suspeitar da possibilidade de o que elas tomam por real poder ter a consistência de meras sombras. Mas como eles podem saber sobre sombras, quando eles nem mesmo querem ser avisados do fogo na caverna e sua luz, ainda que este fogo seja meramente alguma coisa "artificial" e, por esta razão, devendo ser familiar aos seres humanos. Como contraste, a luz solar fora da caverna de nenhum modo é produto da criação humana. No seu brilho, as coisas que tem brotado e estão presentes mostram a si mesmas, imediatamente, sem precisar de obscurecimentos para representá-las. Na "alegoria" as coisas que mostram a si próprias são a "imagem" para as "ideias". Mas no sol na "alegoria" é a "imagem" para aquilo que faz todas as ideias visíveis. É a "imagem” para a ideia de todas as ideias. Isto, posteriormente, de acordo com Platão, é chamado h( tou= a)gaqou=i)de/a, o que se traduz com a "literal" mas pouco desencaminhada frase "a ideia do bem".

As correspondências alegóricas que nós agora apenas temos enumerado entre as sombras e a realidade como experimentada diariamente, entre o brilho do fogo da caverna e as ideias, entre o sol e a ideia mais elevada - não exaurem o conteúdo da "alegoria". De fato, a dimensão apropriada disto nem sequer ainda veio a nossa compreensão. Antes do que apenas reportar sobre os lugares da habitação e as condições das pessoas dentro e fora da caverna, a "alegoria" relata uma série de movimentos. Os movimentos que relata são [216] movimentos de passagem para fora da caverna para a luz diurna e, depois, o retorno da luz diurna para a caverna.

O que acontece nesses movimentos de passagem? O que torna esses eventos possíveis? De onde eles derivam sua necessidade? Que questão está em jogo nessas passagens?

Os movimentos de passagem de fora da caverna para a luz diurna e, em seguida, de volta para a caverna, em cada caso, requer que os olhos se acostumem a mudança do escuro para a claridade e da claridade de volta para o escuro. Em cada vez, ao fazer isso, os olhos experimentam a confusão, certamente por razões opostas em cada caso: 
Sittai $\backslash \kappa \alpha i \backslash$ a)po $\backslash$ dittw=n gi/gnontai e)pitara/ceij o)/mmasin (518 a, 2). "Dois tipos de confusão acontecem para os olhos, e por duas razões”.

Isto significa que existem duas possibilidades. Por um lado, as pessoas podem deixar suas ignorâncias, dificilmente noticiadas, e chegar onde entes se mostram para elas mais essencialmente, mas onde, inicialmente, pessoas não estão preparadas para o essencial. Por outro lado, as pessoas podem debandar da instância do conhecimento essencial e serem forçadas a voltar para o território onde a realidade comum reina suprema, mas sem serem capazes de reconhecer o que é comum e usual ali, como sendo o real.

E exatamente como o olho físico tem que se acostumar, de início, vagarosa e constantemente, de modo idêntico a luz ou a escuridão, assim, do mesmo modo, a alma, pacientemente, e através de uma apropriada série de passos, tem de acostumar-se ao território dos entes para os quais é exposta. Porém, esse processo de ficar acostumado requer que, antes de qualquer outro, a alma em sua totalidade seja movida ${ }^{153}$ ao redor ${ }^{154}$ como considera a direção fundamental de seu esforço, do mesmo modo como o olho pode olhar confortavelmente em qualquer direção apenas quando o corpo todo tem primeiro admitido à posição apropriada.

Todavia, por que esse processo de ficar acostumado a cada território tem que ser lento e constante? A razão é que o mover ao redor tem a ver com o ente do homem e, deste modo, toma lugar no genuíno solo da essência de homem. Isto significa que o rumo normativo que é resultado deste movimento ao redor tem de ser aberto por uma relação que já sustenta nossa essência, e se desenvolve dentro de um comportamento estável. [217]Este processo por meio do qual a essência humana é reorientada e acostumada ao território atribuído a esta em cada ponto é a essência do que Platão chama $\pi \alpha \iota \delta \varepsilon 1 \alpha$ [paideía]. A palavra não se presta para ser traduzida. Como Platão define sua essência, a $\pi \alpha \imath \delta \varepsilon i ́ \alpha$ significa o $\pi \varepsilon \rho 1 \alpha \gamma \omega \gamma \eta \alpha \lambda \eta \zeta \tau \eta \zeta \psi v \chi \eta \zeta$, o guiar de todo ser humano no movimento ao redor da sua essência. Consequentemente, paidei/a é essencialmente um movimento de passagem, isto é, da áj $\alpha 1 \delta \varepsilon v \sigma i ́ \alpha$ para a $\pi \alpha \_\delta \varepsilon i ́ \alpha$. Ao manter-se com seu caráter, de um movimento de passagem, a $\pi \alpha 1 \delta \varepsilon i ́ \alpha$ permanece sempre relacionada a

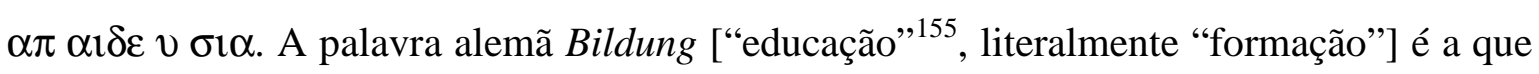
chega mais perto de capturar a palavra a $\pi \alpha \_\delta \varepsilon i ́ \alpha$, mas não inteiramente. Neste caso, é claro,

\footnotetext{
${ }^{153}$ Em inglês: "turned" (movida; girada)

${ }^{154}$ Em inglês: "around" (ao redor; em torno; em volta).

${ }^{155}$ Em inglês: "education" (educação; instrução).
} 
nós precisamos restabelecer a Bildung seu poder original como palavra, e temos que esquecer a má interpretação com a qual foi vítima no final do século dezenove. Bildung ["formação"] significa duas coisas. Por um lado, formação significa formar pessoas, no sentido de imprimir sobre eles um caráter que se abre. Entretanto, ao mesmo tempo, este "formar" das pessoas "forma" (ou imprime um caráter sobre) pessoas, por, anteriormente, tomar medidas em termos de alguma imagem paradigmal, a qual, por esta razão, é chamada de protó-tipo [Vor-bild]. Deste modo, antes e ao mesmo tempo, "formação" significa imprimir um caráter sobre pessoas e guiar pessoas para um paradigma. $\mathrm{O}$ contrário de a $\pi \alpha \iota \delta \varepsilon i ́ \alpha$ é $\alpha \pi \alpha \downarrow \delta \varepsilon v \sigma l \alpha$, falta de formação, onde nenhum rumo fundamental é despertado e aberto, e onde nenhum protó-tipo normativo é posto adiante.

A "alegoria da caverna" concentra seu poder explanador em fazer-nos aptos a ver e saber a essência de contar uma estória por meio de imagens concretas. Ao mesmo tempo, Platão procura evitar falsas interpretações; ele quer mostrar que a essência da paidei/a não consiste em meramente despejar conhecimento em uma alma despreparada como se ela fosse algum recipiente vazio e que resiste esperando. Pelo contrário, a educação genuína prende nossa alma genuína e a transforma em sua totalidade por, primeiramente, nos conduzir para o lugar de nosso ser essencial e ali nos habituar. Que a “alegoria da caverna" é destinada a ilustrar a essência da paideia é exposto com suficiente clareza na sentença perfeita com que Platão introduz a estória no começo do Livro Sétimo:

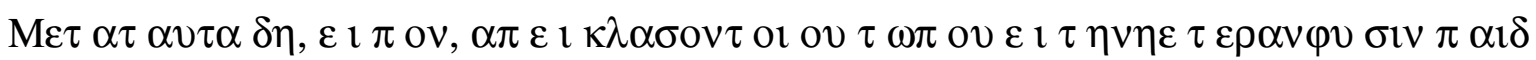
$\varepsilon 1 \alpha \zeta \tau \varepsilon \pi \varepsilon \rho 1 \kappa \alpha \iota \alpha \pi \alpha l \delta \varepsilon v \sigma l \alpha \zeta$. "E depois daquilo, tente fazer aparecer, por você mesmo, a partir do tipo [218] de experiência (a ser apresentada na estória seguinte), uma visão (da essência) igualmente da educação e da falta de educação, a qual (por ter seu lugar próprio em conjunto) diz respeito ao genuíno fundamento do nosso ser como humanos".

A afirmação de Platão é clara: A "alegoria da caverna" ilustra a essência da "instrução" 156 . Como contraste, a interpretação da "alegoria", que nós agora iremos empreender, pretende chamar a atenção para a "doutrina" platônica da verdade. Nós não estaríamos sobrecarregando a "alegoria" com alguma coisa alheia a ela? A interpretação ameaça se degenerar numa reinterpretação que faz violência ao texto. Deixe esta aparência permanecer até nós termos confirmado nosso discernimento de que o pensamento de Platão se sujeita a uma transformação na essência da verdade, que se torna a lei oculta

${ }^{156}$ Aqui optamos pela palavra "instrução" ("education": Bildung). 
governadora do que o pensador expressa. De acordo com nossa interpretação, conferida como necessária para uma futura necessidade, a "alegoria" não apenas ilustra a essência da instrução, mas, ao mesmo tempo, abre nossos olhos para uma transformação na essência da "verdade". Se a "alegoria" pode mostrar ambas, não teria de ser o caso de que uma relação essencial se afirmasse entre "instrução" e "verdade"? Esta relação, de fato, se obtém. E ela consiste no fato de que a essência da verdade, e o tipo de transformação que ela aqui primeiramente sofre, torna possível a "instrução" nas suas estruturas básicas.

Todavia, o que é isso que conecta "instrução" e "verdade" juntas em uma unidade original e essencial?

П $\alpha 1 \delta \varepsilon i ́ \alpha$ significa movimentar ao redor a totalidade do o ser humano. Isto significa remover os seres humanos da região onde eles primeiro encontraram as coisas, se transferiram e se habituaram, a outro domínio onde seres aparecem. Esta transferência é possível apenas pelo fato de que tudo que foi antes manifestado aos seres humanos, bem como pela via na qual foi manifestado, se transformou. Tudo o que foi desocultado aos seres humanos em qualquer tempo dado, bem como a maneira de sua desocultação, tem que ser transformado. Em grego desocultação é chamada $\alpha \lambda \eta \varepsilon \imath \alpha$, uma palavra que nós traduzimos como "verdade". E, por um longo tempo no pensamento ocidental, a "verdade" significou a concordância da representação no pensamento com a coisa mesma: adaquatiointellectuset rei. [219]

Entretanto, se nós não estivermos satisfeitos em meramente traduzir as palavras paidei/a e a)lh/qeia literalmente, e se ao invés disto nós tentarmos pensar completamente a questão de acordo com a maneira grega de conhecimento, e considerarmos a questão essencial que está em jogo nessas traduções, então imediatamente "educação" e "verdade" viriam juntas como em uma unidade essencial. Se nós tomarmos seriamente o conteúdo essencial do que a palavra $\alpha \lambda \eta \varepsilon \imath$ ldesigna, então nós teremos que perguntar: De qual perspectiva Platão aproxima sua determinação da essência da desocultação? Para a resposta a esta questão nós aludimos ao conteúdo próprio da “alegoria da caverna”. A resposta irá demonstrar, igualmente, o fato de que, e o modo no qual, a "alegoria" lida com a essência da verdade.

O "desoculto" e sua "desocultação" designam, a cada ponto, o que está presente e manifesto na região onde os seres humanos sucedem de habitar. Porém, a "alegoria" conta a estória de passagens de uma morada para outra. Deste modo, esta estória 
é dividida, de uma forma geral, em uma série de quatro diferentes locais de moradas, em gradações específicas para cima e para baixo. As distinções entre os locais de moradas ${ }^{157}$ e os degraus ${ }^{158}$ no interior dos movimentos de passagem são fundadas nos diferentes tipos de $\alpha \lambda \eta \theta \varepsilon \zeta$ normativas em cada nível, isto é, os diferentes tipos de "verdade" que são dominantes em cada plano ${ }^{159}$. Por essa razão, de uma forma ou de outra, nós temos que considerar e designar o que o $\alpha \lambda \eta \theta \varepsilon \zeta$, o desoculto, é em cada plano.

No primeiro plano, as pessoas vivem acorrentadas dentro da caverna, absortas no que elas imediatamente encontram. A descrição deste local de morada termina com uma sentença

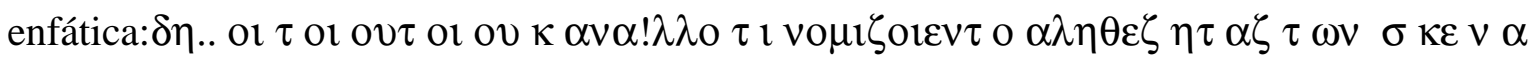
$\sigma \tau \omega \nu \sigma \kappa \imath \alpha \zeta$ (515 c1-2). "De nenhuma forma, então, aqueles, que estão acorrentados desta maneira, considerariam qualquer outra coisa como desoculta, exceto as sombras dispostas pelos objetos".

O segundo plano narra sobre a remoção das correntes. Mesmo que ainda confinados na caverna, aqueles prisioneiros são agora livres em um certo sentido. Agora eles podem se mover ao redor em todas as direções. Tornou-se possível ver as coisas mesmas que eram [220] previamente carregadas ao longo e por trás deles. Aqueles que

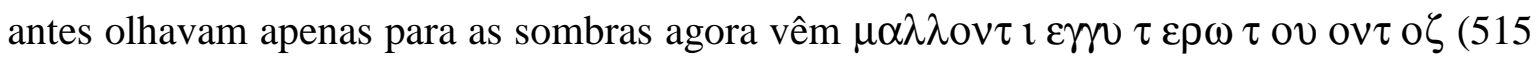
d2), "um pouco mais próximo do que é". As coisas mesmas oferecem suas formas visíveis, de um certo modo, especificamente, no brilho do fogo artificial da caverna, e não estão mais ocultas pelas sombras que projetam. Na medida em que alguém encontra nada além de sombras, estas mantêm o olhar fixo do cativo e, deste modo, se insinuam no lugar das coisas mesmas. Porém, quando o olhar fixo de alguém é liberto de seu cativeiro das sombras, se torna possível para a pessoa que foi liberta, entrar na área do que é $\alpha \lambda \eta \theta \varepsilon \sigma \tau \varepsilon \rho \alpha$ (515 d6), "mais desoculto". E, ainda, isso tem que ser dito dele que foi

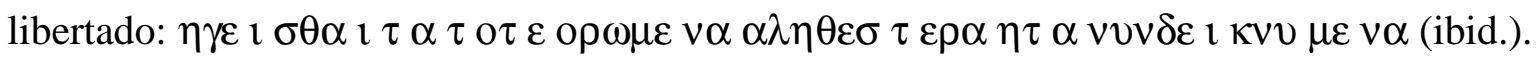
"Ele irá considerar (as sombras) que ele viu depois (sem qualquer ajuda) como mais desocultas do que o que está agora sendo mostrado (para ele, por alguém de fato)".

\footnotetext{
${ }^{157}$ Em alemão: "Aufenthalte".

${ }^{158}$ Em alemão: "Stufen".

${ }^{159}$ Em inglês: "stage" (degrau; palco; plano; nível).
} 
Por que isso é assim? O brilho do fogo, para o qual seus olhos não estão adaptados, cega aqueles que foram libertados. Esta cegueira os impede de ver o fogo mesmo e de apreenderem como o seu brilho ilumina as coisas e, assim, permite essas coisas aparecerem pela primeira vez. Isto é o motivo daqueles que foram cegos não poderem compreender que, o que eles previamente viram, era meramente sombras daquelas coisas, dispostas pela luz deste mesmo fogo. Certamente, aqueles que foram libertados veem agora outras coisas além das sombras, mas tudo isto aparece apenas em confusão. Por contraste, o que eles veem na luz refletida do, ainda, invisível e não descoberto fogo, isto é, as sombras, aparecem em nítidos contornos. Porque pode ser visto sem confusão, esta consistência com que as sombras aparecem tem que atingir aqueles que tem sido libertos, como sendo "mais desoculta". Entretanto, a palavra a)lhqe/j ocorre de novo no fim da descrição do segundo degrau, e agora no degrau comparativo: a)lhqe/stera, o "mais desoculto". A "verdade" mais apropriada se encontra nas sombras. Logo, mesmo aqueles que foram libertos de suas correntes, ainda avaliam erradamente o que eles pressupõem como verdade, porque lhes falta a condição prévia para "avaliar", isto é, a liberdade. Certamente, a remoção das correntes traz uma certa[221] liberação, mas o deixar solto não é, ainda, a liberdade real.

A liberdade real é alcançada apenas no terceiro plano. Aqui alguém que foi desacorrentado é, ao mesmo tempo, transportado para fora da caverna, "ao aberto". Ali, sobre a terra, todas as coisas são manifestas. A aparência que mostra o que as coisas são agora, não mais aparecerá meramente no brilho artificial e confuso do fogo, dentro dos limites da caverna. As coisas mesmas se encontram ali na força vinculante e na validez da sua própria aparência. A abertura, dentro da qual está agora colocado o prisioneiro liberto, não significa a imensidão de algum espaço aberto; antes, o aberto estabelece os limites para as coisas e é a característica do poder vinculador do brilho radiante da luz solar, o qual é também visto. A aparência que mostra o que as coisas mesmas são, as $\varepsilon 1 \delta \eta$ (idéias), constituem a essência em cuja luz cada ente individual se mostra como isto ou aquilo, e apenas neste auto-mostrar que a coisa visível tornou-se desoculta e acessível.

O nível da morada que agora foi alcançado é, como nos outros, definido em termos do que é normativamente e propriamente desoculto neste nível. Todavia, logo no começo de sua descrição do terceiro plano, Platão fala $\tau \omega v \vee v v \lambda \varepsilon$ yo $\mu \varepsilon v \omega v \alpha \lambda \eta \theta \omega \nu$ (516 a3), “do que é agora endereçado como o desoculto". Este desoculto é $\alpha \lambda \eta \theta \varepsilon \sigma \tau \varepsilon \rho \alpha$, 
ainda mais desoculto do que eram as coisas iluminadas pelo fogo artificial na caverna, em sua distinção para com as sombras. $\mathrm{O}$ desoculto que é agora alcançado é o mais desoculto de todos: $\tau \alpha \alpha \lambda \eta \theta \varepsilon \sigma \tau \alpha \tau \alpha$. Ainda que, em verdade, Platão não usa esta palavra nesta parte do texto, ele menciona $\tau$ o $\alpha \lambda \eta \theta \varepsilon \sigma \tau \alpha \tau$ ov, o mais desoculto, na correspondente $\mathrm{e}$ igualmente importante discussão no começo do Livro VI de A República. Aqui (484 c, 5 ff.) ele menciona ... $\varepsilon 1 \zeta \tau o \alpha \lambda \eta \theta \varepsilon \sigma \tau \alpha \tau o v \alpha \pi o \beta \lambda \varepsilon \pi$ ov $\tau \varepsilon \zeta$, "aqueles que olham fixamente sobre o mais desoculto". O mais desoculto mostra-se em cada caso no o que é do ente. Sem este sentido do mostrar o que é (isto é, as ideias), toda e qualquer coisa em específico - de fato, absolutamente tudo - permaneceria oculta. "O mais desoculto" é assim chamado porque é o que [222] aparece, anteriormente, em tudo o que aparece, e faz tudo o que aparece ser acessível.

Já dentro da caverna, mudar o olhar das sombras para o brilho do fogo e focar nas coisas reveladas pela luz do fogo, era uma tarefa dificultosa que se provou malsucedida; mas agora estando livre no aberto, que está fora da caverna, requer completamente todo esforço e paciência. A liberação não acontece pela simples remoção das correntes, e não consiste numa liberdade descontrolada; antes, ela primeiro começa com o esforço contínuo de habituar o olhar a ser fixado sobre o firme limite das coisas que se encontram nas suas formas visíveis. A liberação autêntica é a perseverança de ser orientado para o que aparece na sua forma visível, e o qual é o mais desoculto neste aparecer. A liberdade existe apenas como a orientação que é estruturada neste caminho. Além do mais, esta orientação como um movimento para... sozinha realiza a essência da $\pi \alpha 1 \delta \varepsilon \downarrow \alpha$ como um movimento ao redor. Deste modo, a realização da essência da "instrução" 160 pode ser alcançada apenas na região do, e sobre a base do, mais desoculto, isto é, a $\alpha \lambda \eta \theta \varepsilon \sigma \tau \alpha \tau$ o $v$, isto é, o mais verdadeiro, isto é, a verdade no sentido próprio. A essência da "educação" é fundada na essência da "verdade".

Entretanto, porque a essência da $\pi \alpha i \delta \varepsilon \imath \alpha$ consiste na $\pi \varepsilon \rho 1 \alpha \gamma \omega \gamma \gamma^{\prime} \eta \lambda \eta \zeta \tau \eta \zeta \psi v \chi \eta \zeta$, então à medida que ela é como um movimento ao redor, ela constantemente perdura numa superação da a0paideusi/a. A $\pi \alpha \imath \delta \varepsilon \imath$ l $\alpha$ contém dentro de si uma relação anterior com a falta de instrução. E se, de acordo com a própria interpretação de Platão, a "alegoria da caverna" é admitida por esclarecer a essência da $\pi \alpha \imath \delta \varepsilon \imath$, então este esclarecimento tem também que fazer expressar precisamente este

160 "Educação" ou "formação". 
fator essencial, a constante superação da falta de instrução. Por isso, a narração da estória não termina, como é frequentemente admitido, com a descrição do nível mais alto alcançado na ascensão para fora da caverna. Pelo contrário, a "alegoria" inclui a estória da descida da pessoa liberta de volta para caverna, de volta para aqueles que ainda estão acorrentados. Aquele que foi liberto é, igualmente, suposto a liderar essas pessoas para longe do que é oculto para elas e trazê-las face-a-face com o mais desoculto. Porém, o assim chamado liberador já não mais sabe seu rumo ao redor da caverna e [223] corre o perigo de sucumbir ao poder catastrófico do tipo de verdade que é ali reguladora, o perigo de ser dominado pela reivindicação da "realidade" comum como a única realidade. O liberador é tratado com a possibilidade de ser levado a morte, uma possibilidade que se torna uma realidade no destino do "professor" de Platão, Sócrates.

O retorno para a caverna e a batalha promovida dentro dela entre o liberador e os prisioneiros, que resistem a toda liberação, por si mesmo compõe o quarto plano da "alegoria", no qual a estória atinge a conclusão. Reconhecidamente a palavra a)lhqe/j não é mais usada nesta parte da narrativa. De modo algum, este plano também tem que lidar com o desoculto, que condiciona a área da caverna, que agora a pessoa livre visita mais uma vez. Porém, não era o "desoculto" - as sombras -, que regula a caverna, já mencionado no primeiro plano? Sim, era. Mas dois fatores são essenciais para o desoculto: de uma maneira ou de outra, não apenas torna acessível tudo o que aparece e o mantém revelado no seu aparecer, mas também, constantemente, supera uma ocultação do oculto. $\mathrm{O}$ desoculto tem que ser separado da ocultação; em um dado sentido, ele tem que ser roubado da ocultação. Originalmente, para os gregos ${ }^{161}$, ocultação, como um ato de auto-ocultar, permeou a essência do ente e, assim, também determinou os entes nas suas presentificações e acessibilidades ("verdade"); e esse é o motivo da palavra grega que os romanos denominam "veritas", e nós "verdade", a ser distinguida pela alfa-privativa $(\alpha \lambda \eta \theta \varepsilon \imath \alpha)$. Verdade ${ }^{162}$ originalmente significa aquilo que foi arrancado da ocultação ${ }^{163}$. Verdade é, deste modo, um arrancar para fora em cada caso, na forma de um descobrimento. A ocultação pode ser de vários modos: fechamento, ocultamento, disfarce, encobrimento, mascaramento, dissimulação. E uma vez que, de acordo com a "alegoria" de Platão, o desoculto supremo [224] tem que ser arrancado de um ocultamento baixo e

\footnotetext{
${ }^{161}$ Nota de Heidegger na edição Geistige Überlieferung, 1942: "Heráclito, fragmento 123".

162 Nota de Heidegger na edição Geistige Überlieferung, 1942: "no sentido daquilo que é verdade". [imSinnedesWahren].

${ }^{163}$ Nota de Heidegger na edição Geistige Überlieferung, 1942: “[de um] ocultamento” [Verbergung].
} 
obstinado, por esta razão o movimento de saída da caverna para o aberto e para a luz do dia é uma luta de vida ou morte. O degrau quatro da "alegoria" nos oferece um olhar rápido do fato de que a "privação" - alcançando o desoculto pelo arrancar para fora - pertence a essência da verdade. Portanto, como em cada um dos três planos prévios da "alegoria da caverna", o plano quatro também lida com a $\alpha \lambda \eta \theta \varepsilon$ i $\alpha$.

Esta "alegoria" pode ter a estrutura de uma imagem da caverna sob qualquer condição apenas porque ela é anteriormente co-determinada pela experiência fundamental da $\alpha \lambda \eta \theta \varepsilon \imath$, a desocultação dos entes, o que era alguma coisa auto-evidente para os gregos. Não seria para outra coisa a caverna subterrânea, exceto para algo aberto em si mesmo que permanece ao mesmo tempo coberto por uma abóbada e, apesar da entrada, desmurada e cercada por terra circundante? Este cercado do tipo caverna que é aberto dentro de si mesmo, e que o cerca e, portanto, oculta, refere-se, igualmente, do mesmo modo, a algo para fora, o desoculto que se expande para fora na luz sobre a terra. Apenas a essência da verdade, entendida no sentido grego original da $\alpha \lambda \eta \theta \varepsilon \imath \alpha-a$ desocultação que é relacionada ao ocultado (para algo dissimulado e disfarçado) -, tem uma relação essencial com esta imagem de uma caverna subterrânea. Onde quer que a verdade tenha outra essência, onde quer que ela não seja ocultação ou, ao menos, não seja co-determinada pela ocultação, nesse lugar uma "alegoria da caverna" não tem fundamento como uma ilustração.

E, ainda, mesmo que a $\alpha \lambda \eta \theta \varepsilon 1 \alpha$ seja propriamente experimentada na "alegoria da caverna" e seja mencionada nela em pontos importantes, de modo algum, no lugar da desocultação, outra essência da verdade se impulsionará para frente. Entretanto, isto também implica em dizer que a desocultação ainda preserva uma certa prioridade.

A apresentação da "alegoria", juntamente com a própria interpretação de Platão sobre ela, compreende a caverna subterrânea e a área de fora, quase que autoevidentemente, como o território dentro do qual os eventos da estória são exauridos. Porém, em tudo isso, o que é essencial são os movimentos de passagem: a ascensão do domínio [225] da luz do fogo artificial para o brilho da luz solar, assim como, o descenso da fonte de toda luz de volta para a escuridão da caverna. O poder ilustrativo da "alegoria da caverna" não vem da imagem da clausura da abóbada subterrânea e da prisão das pessoas dentro de seus limites, como tampouco vem da visão do espaço aberto fora da caverna. Para Platão, antes, o poder expositivo por trás das imagens da "alegoria" está 
concentrado no papel executado pelo fogo, o brilho do fogo e a disposição das sombras, a claridade do dia, a luz solar e o sol. Tudo depende do resplandecer adiante de tudo o que aparece e no fazer possível sua visibilidade. Certamente a desocultação é mencionada em seus vários degraus, mas é considerada simplesmente em termos de como faz tudo o que aparece ser acessível na sua forma visível $(\varepsilon \imath \delta o \zeta)$ e em termos de como faz esta forma visível, como aquela que se mostra ( $1 \delta \varepsilon \alpha)$ ser visível. Esta reflexão propriamente dita se foca sobre o aparecer da forma visível, o qual é concedido no próprio brilho do resplandecer. A forma visível oferece uma visão daquilo que se apresenta como qualquer ente dado. O reflexo propriamente dito objetiva a i0de/a. A "idéia" é a forma visível que oferece uma visão do que se apresenta. A i0de/a é o puro resplandecer no sentido da frase "o sol resplandece”. A "ideia" não permite que qualquer coisa (por trás dela) "resplandeça e apareça" ["erscheinen"]; ela mesma é o que resplandece, e o que concerne apenas ao resplandecer em si mesmo. A i0de/a é aquilo que pode resplandecer ["das Scheinsame”]. A essência da idéia consiste na sua habilidade de clarear e ser vista ["ScheinundSichtsamkeit”]. Isto é, o que nos leva para a presença, especificamente a vinda para a presença do que um ente é em qualquer instância dada. O ente se torna presente em cada caso em seu o que é. Mas depois de tudo, a vinda para presença é a essência do ser. Para Platão, este é o motivo da essência propriamente dita do ser consistir no o que é. Mesmo uma terminologia posterior mostra isto: quidditas, e não existentia, é o verdadeiro esse, isto é, essentia. O que a idéia, no seu resplandecer adiante, põe em visão e, desse modo, nos permite ver, é - para o olhar focado sobre a idéia - a desocultação daquilo que aparece como ideia. Esta desocultação é, anteriormente e, por si mesma, entendida como aquilo que é compreendido na compreensão da $\imath \delta \varepsilon \alpha$, como aquilo que é conhecido ( $\gamma \gamma \nu \omega \sigma \chi 0 \mu \varepsilon v o v)$ no ato de conhecer ( $\gamma \gamma \omega \sigma \chi \varepsilon \imath v)$. Apenas nesta revolução platônica

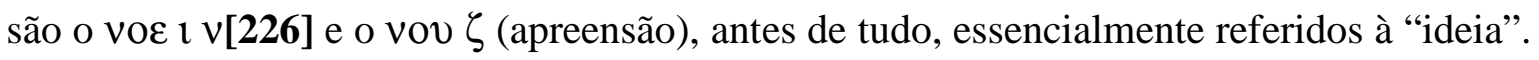
A adoção desta orientação para as ideias, doravante, determina a essência da apreensão ["Vernehmung”] e, subseqüentemente, a essência da "razão" ["Vernunft”].

A "desocultação" agora se refere ao desoculto sempre como aquilo que é acessível graças à habilidade da ideia resplandecer. Mas à medida que o acesso é, necessariamente, executado por meio do "ver", a desocultação é unida na "relação" com o ver, se torna "relativa" ao ver. Assim, ao final do Livro VI da República, Platão desenvolve a pergunta: $O$ que faz a coisa vista e o ato de ver serem o que são em sua relação? O que abarca o espaço entre eles? Que jugo (zugo/n 508 a, 1) mantém os dois 
juntos? A "alegoria da caverna" foi escrita a fim de esclarecer a resposta, que anuncia uma imagem: O sol, como fonte de luz, empresta visibilidade para tudo o que é visto. Porém, o ver vê o que é visível apenas à medida que o olho é $\eta \lambda \imath$ o $1 \delta \varepsilon \zeta$, "como sol” por ter o poder de participar no tipo de essência do sol, que é, seu resplandecer. O olho em si "emite luz" e se devota ao resplandecer, e deste modo, é capaz de receber e apreender tudo o que aparece. Em termos do que está em jogo, a imagem significa um relacionamento que $\begin{array}{lllllll}\text { Platão } & \text { expressa } & \text { como } & \text { segue } & \text { (VI, } & 508 & \text { e, }\end{array}$

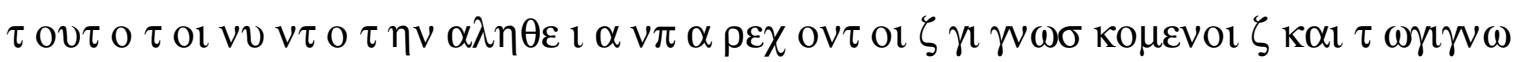

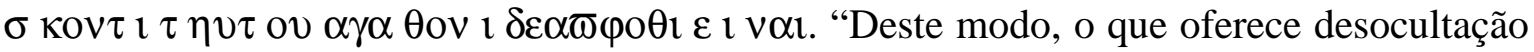
para a coisa conhecida e também concede poder (de conhecimento) para o conhecedor, isto, eu digo, é a ideia do bem".

A "alegoria" menciona o sol como a imagem para a ideia do bem. Em que consiste a essência desta ideia? Como i0de/a, o bem é algo que resplandece, assim, algo que oferece visão, deste modo, em ordem seguida, algo visível e, por esta razão, conhecível, de fato:

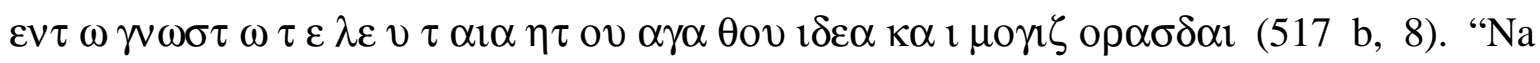
esfera do que pode ser conhecido, a ideia do bem é o poder de visibilidade que realiza todo resplandecer adiante e que, portanto, é adequadamente visto apenas ao final, [227] de fato, é, realmente, dificilmente (apenas com grandes dores) visto, sob qualquer condição”.

Nós traduzimos $\tau o \alpha \gamma \alpha \theta o v^{164}$ com o aparentemente compreensível termo "o bem". Mais frequentemente, nós pensamos nele como o "bem moral", assim chamado porque é conforme a lei moral. Esta interpretação é alheia ao pensar grego, mesmo que a interpretação de Platão de $\alpha \gamma \alpha \theta$ ov como idéia ofereça a ocasião para pensamento de "o bem" "moralmente" e, enfim, suponha essa como um "valor". A noção de valor que entra em moda no século dezenove, no despertar da moderna concepção de "verdade" é a derradeira e, ao mesmo tempo, a mais fraca descendência de $\alpha \gamma \alpha$ oov. À medida que o "valor" e a interpretação, em termos de "valores", sustentam a metafísica de Nietzsche - na forma absoluta de "reavaliação de todos valores" - e uma vez que, para ele, todo conhecimento parte de uma origem metafísica de "valor", neste âmbito Nietzsche é o mais desenfreado discípulo de Platão na história da metafísica ocidental. Entretanto, na

\footnotetext{
${ }^{164}$ Nota de Heidegger a edição de 1947: "O $\alpha \gamma \alpha$ $\theta$ ov é certamente uma iOde/a, mas não mais presente-para (ou presente-até que) e, portanto, dificilmente visível". [ $\alpha \gamma \alpha \theta 0 v$ zwarı $\delta \varepsilon \alpha$, abernichtmehranwesend, deshalbkaumsichtbar].
} 
medida em que ele entende valor como condição de uma possibilidade de "vida", uma condição pressuposta pela "vida mesma", Nietzsche sustenta a essência do $\alpha \gamma \alpha \theta 0 \mathrm{v}$, com muito menos prejuízo do que aqueles que seguem o absurdo disparate dos "valores intrinsecamente validos".

Além disso, se nós seguirmos a moderna filosofia e pensarmos na essência da "ideia" como perceptio ("representação subjetiva"), então nós encontraremos na "ideia do bem" um "valor" presente em algum lugar em si mesmo, do qual, ademais, nós temos uma "ideia". Esta "ideia" tem que naturalmente ser a mais elevada, porque o que importa é que tudo transcorra no "bem" (no bem-estar da prosperidade ou na regularidade de uma ordem). Dentro dos limites desta via moderna do pensar, nada mais absolutamente existe para compreender da essência original da $\imath \delta \varepsilon \alpha \tau$ ov $\alpha \gamma \alpha \theta$ ov.

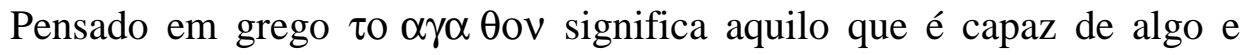
possibilita outro a ser capaz de algo. Toda i0de/a, a forma visível de [228] algo, oferece um olhar para o que um ente é em cada caso. Deste modo, no pensamento grego, as "ideias" possibilitam algo aparecer em seu o que é e, assim, estar presente em sua permanência. As ideias são o que é em tudo que é. Portanto, o que faz toda ideia ser capaz como uma ideia na expressão de Platão: a ideia de todas as ideias - consiste em fazer possível o aparecer, em toda sua visibilidade, de todo presente. A essência de toda ideia, certamente, consiste no fazer possível e no possibilitar o resplandecer, que permite uma visão da forma visível. Por essa razão, a ideia das ideias é aquilo-que-possibilita como tal, $\tau$ o $\alpha \gamma \alpha \theta$ ov. Isto causa a resplandecência de tudo que pode resplandecer, e, consequentemente, é aquilo mesmo que propriamente aparece pela resplandecência, aquilo que é o mais apto a resplandecer em sua resplandecência. Por esta razão, Platão designa o $\alpha \gamma \alpha \theta$ ov também como $\tau$ ov ov $\tau$ o $\zeta \alpha \operatorname{vo} \tau \alpha \tau$ ov (518 c, 9), "aquilo que mais resplandece (o mais apto a resplandecer) dos entes".

A expressão "a ideia do bem" - que tanto desencaminhou o pensamento moderno - é o nome para aquela distinta ideia que, como ideia das ideias, é o que possibilita tudo mais. Esta ideia, que sozinha pode ser chamada "o bem", permanece ${ }^{1} \delta \varepsilon \alpha \tau \varepsilon \lambda \varepsilon v \tau \alpha \iota \alpha$, porque na sua essência da ideia alcança seu cumprimento, isto é, começa a ser, de maneira que disto também surge primeira a possibilidade de todas as outras ideias. O bem pode ser chamado de "ideia mais elevada" num duplo sentido: Ela é a mais elevada na hierarquia do fazer possível; e ver isto é uma tarefa muito árdua de olhar 
diretamente para cima. Apesar da dificuldade de compreender isto adequadamente, esta ideia, admitida a essência da ideia, no sentido grego, tem que ser chamada "o bem", de qualquer maneira, constantemente, sempre encontra-se na visão, onde quer que todo ente sob qualquer condição se mostre. Até mesmo onde as pessoas veem apenas sombras, cujas essências ainda ficam ocultadas, ali também o brilho do fogo tem que resplandecer, mesmo que as pessoas não compreendam adequadamente este resplandecer e experimentem isso como advindo do fogo, e mesmo que aqui, sobre tudo, elas ainda estejam inconscientes de que o fogo é apenas um resultado ( $\varepsilon \chi$ yovov, VI, 507 a, 3) do sol. Dentro da caverna, o sol permanece invisível e, não obstante, mesmo [229] as sombras se nutrem de sua luz. Mas o fogo na caverna, que torna possível uma apreensão das sombras, que não percebem a sua própria essência, é a imagem para o fundamento não reconhecido de toda experiência do ente, que os pretende sem os conhecer como tal. Todavia, o sol por seu resplandecer não apenas confere brilho sobre tudo que aparece, e, juntamente com este brilho, a visibilidade e, assim, a "desocultação". Mas não apenas isto. Ao mesmo tempo, seu resplandecer irradia calor e, por esta incandescência, possibilita tudo que "vem a ser" a sair para a visibilidade da sua duração permanente (509 b).

Entretanto, uma vez que o sol mesmo é verdadeiramente visto $(o \phi \theta \varepsilon \imath \sigma \alpha \delta \varepsilon)$ - ou, caindo numa metáfora, uma vez que a ideia mais elevada é tomada em vista de,

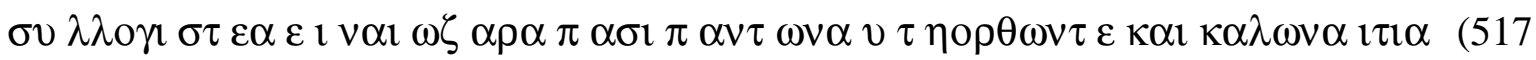
c), “então pode-se tirar a conclusão - obtida em conjunto (da própria ideia mais elevada) que obviamente para todas as pessoas esta ideia do bem é a fonte original [Ur-sache], igualmente de tudo que é correto (no comportamento humano) e de tudo que é belo" - que é, aquilo que se manifesta para o comportamento de tal forma a trazer o resplandecer de sua forma visível a aparência. A ideia mais elevada é a origem, isto é, a fonte original [Ursache] de todas as "coisas" ["Sachen"] e de suas coisidades [Sachheit]. "O bem" garante o aparecer da forma visível, na qual tudo o que é presente tem sua estabilidade no que é. Mediante esse garantir, o ente é mantido dentro do ser e, assim, é "salvo".

No que diz respeito a todas as formas de discernimento prudencial ${ }^{165}$ que informa a atividade prática, segue-se da essência da ideia mais elevada

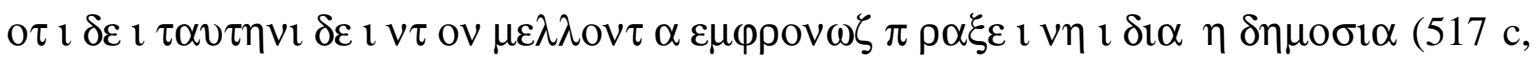

${ }^{165}$ Em inglês: "prudential”. 
4/5), "que qualquer um que está preocupado com o discernimento prudencial, mesmo em assuntos pessoais ou em negócios públicos, tem que ter essa visão (a saber, a ideia que, a medida que ela é a possibilitadora da essência da ideia, é denominada o bem)". Quem quer que queira atuar em um mundo determinado por "as ideias", precisa, antes de qualquer coisa, de uma visão das ideias. E, assim, a própria essência da $\pi \alpha \imath \delta \varepsilon \imath \alpha$ consiste em fazer o ser humano livre e afirmá-lo para a claridade e constância do discernimento dentro da essência. Agora, uma vez que, de acordo com a própria interpretação de Platão, a "alegoria da caverna" é acreditada por oferecer uma imagem concreta da essência da $\pi \alpha \imath \delta \varepsilon \imath \alpha$, [230] ela tem também que contar a ascensão para a visão da ideia mais elevada.

Porém, não seria o caso de a "alegoria da caverna" lidar especificamente com a $\alpha \lambda \eta \theta \varepsilon l \alpha$ ? Não absolutamente. E, ainda mais, permanece o fato de que esta "alegoria" contém a "doutrina" de Platão sobre a verdade, visto que a "alegoria" é fundada no evento tácito por meio do qual a $1 \delta \varepsilon \alpha$ ganha dominância sobre a $\alpha \lambda \eta \theta \varepsilon \imath \alpha$. A "alegoria" coloca em imagens o que Platão diz sobre ${ } \delta \varepsilon \alpha \tau$ ov $\alpha \gamma \alpha \theta 0 v$, a saber,

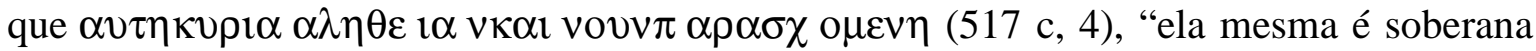
visto que ela confere desocultação (sobre o que se mostra) e, ao mesmo tempo, concede apreensão (do que é desoculto)". A $\alpha \lambda \eta \theta \varepsilon ı \alpha$ vem sob o jugo da $\imath \delta \varepsilon \alpha$. Quando Platão diz que a $1 \delta \varepsilon \alpha$ é a soberana que permite a desocultação, ele conduz a algo não dito, isto é, que doravante a essência da verdade não é, como a essência da desocultação, o desdobrar-se da própria e essencial plenitude, mas, antes, o deslocar-se para essência da i0de/a. A essência da verdade desiste de seu traço fundamental de desocultação.

Se nosso comportamento com os entes é sempre, e em todo lugar, um assunto do i0dei n da i0de/a, a visão da "forma visível", então todos nossos esforços devem ser concentrados, sobretudo, em fazer tal visão possível. E isto requer a visão correta. Já dentro da caverna, quando aqueles que foram libertos desviaram-se das sombras e dirigiram-se para as coisas, elas dirigiram seu olhar para aquilo que, em comparação com

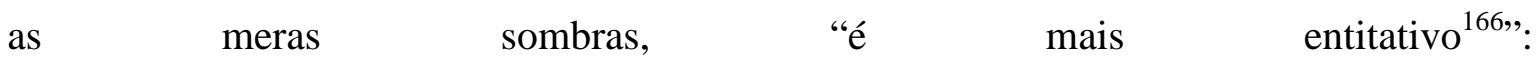

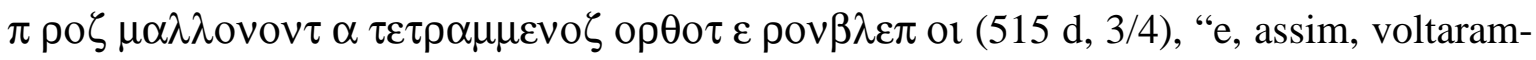
se para o que é mais entitativo, elas devem certamente ver mais corretamente". O movimento de passagem de um lugar para outro consiste no processo por meio do qual o olhar atento se torna mais correto. Tudo depende da $0 \rho \theta 0 \tau \eta \zeta$, da correção do olhar atento.

${ }^{166}$ Em inglês: "in being”. 
Através desta correção, o ver ou conhecer se tornam algo correto, de modo que, no final, se dirige diretamente para a ideia mais elevada e se fixa neste "alinhamento direto". Em este se dirigir, a apreensão se conforma ao que é para ser visto: a "forma visível" do ente. O que resulta desta conformação da apreensão, como uma $1 \delta \varepsilon ı$, para a $1 \delta \varepsilon \alpha$ é um o $\mu \circ \downarrow \omega \sigma l \zeta$, um acordo do ato de conhecer com [231] a coisa mesma. Deste modo, a prioridade da $1 \delta \varepsilon \alpha$ e da $1 \delta \varepsilon \imath v$ sobre a $\alpha \lambda \eta \theta \varepsilon \imath \alpha$ resulta na transformação da essência da verdade. A verdade se torna $0 \rho \theta 0 \tau \eta \zeta$, a correção do apreender e do afirmar.

Com essa transformação da essência da verdade, ocorre ali, ao mesmo tempo, uma mudança do lugar da verdade. Como desocultação, a verdade ainda é um traço fundamental dos entes mesmos. Porém, como correção do "olhar", ela se torna uma característica do comportamento humano com respeito aos entes.

Todavia, em um certo sentido, Platão tem que firmar-se na "verdade" ainda como uma característica dos entes, porque um ente, como algo presente, tem o ser precisamente no aparecer, e o ser traz a desocultação com ele. Mas, ao mesmo tempo, a indagação pelo desoculto se desloca na direção do aparecer da forma visível, e, conseqüentemente, na direção da correção do ver. Por esta razão, existe uma ambiguidade necessária na doutrina de Platão. Esta é, precisamente, a que atesta para a anteriormente tácita, mas agora expressa, mudança na essência da verdade. A ambiguidade é claramente manifestada no fato de que enquanto a $\alpha \lambda \eta \theta \varepsilon \imath \alpha$ é o que é nomeado e discutido, é a

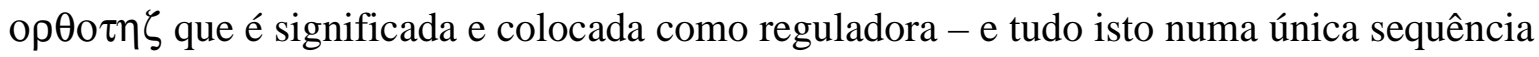
de pensamento.

A ambiguidade na determinação da essência da verdade pode ser vista numa única sentença tirada da seção que contém a própria interpretação de Platão da "alegoria da caverna" (517 b, 7 até c, 5). O pensamento condutor é que a idéia mais elevada une em conjunto o ato de conhecer e o que é conhecido. Porém, esta relação é entendida de dois modos. Em primeiro lugar, e, portanto, normativamente, Platão diz: $\eta \tau$ ov $\alpha \gamma \alpha \theta$ ov [a ideia do bem] é $\pi \alpha \nu \tau \omega \nu$ o $\rho \theta \omega \nu \tau \varepsilon \kappa \alpha \iota \kappa \alpha \lambda \omega \nu \alpha \imath \tau \imath \alpha$, "a fonte original (i. e., a possibilitadora da essência) de todo correto bem como de todo belo". Mas então é dito que a ideia do bem é $\kappa v \rho \rho \alpha \alpha \lambda \eta \theta \varepsilon l \alpha v \kappa \alpha l$ vovv, "a soberana que confere desocultação bem como apreensão". Essas duas afirmações não correm em paralelo, de

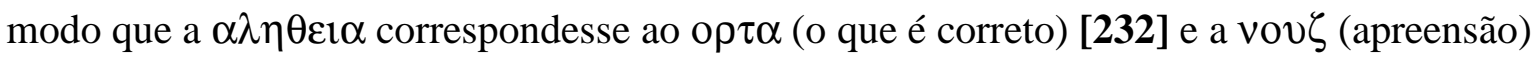


correspondesse ao $\kappa \alpha \lambda \alpha$ (o que é belo). Antes, a correspondência trabalha em modelo cruzado. Correspondente ao o $\tau \tau$, o que é correto e sua correção, existe a apreensão correta, e correspondente ao que é belo, existe o desoculto; a essência do belo encontra-se em ser $\varepsilon \kappa \varphi \alpha v \varepsilon \sigma \tau \alpha \tau o v$ (cf. Fedro), aquilo que, mais do que tudo e mais puramente resplandecente de, e a partir de, si mesmo, mostra a forma visível e, deste modo, é desoculto. Ambas as sentenças falam da primazia da ideia do bem como possibilitadora da correção do conhecer e a desocultação do conhecido. Aqui a verdade ainda é, antes e ao mesmo tempo, desocultação e correção, embora a desocultação já esteja sob o jugo da i0de/a. A mesma ambiguidade na determinação da essência da verdade prevalece também em Aristóteles. No capítulo final do Livro IX da Metafísica (Met., @, 10, 1051 a 34 ss.) onde o pensamento aristotélico sobre o ser dos entes alcança o cume, a desocultação é o todo poderoso traço fundamental dos entes. Mas Aristóteles pode dizer também

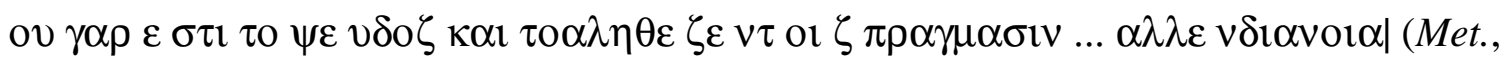
E, 4, 1027 b, 25 ss.). "De fato, o falso e o verdadeiro não estão nas coisas (mesmas) ... mas no entendimento".

O julgamento intelectual e a afirmação são, agora, o lugar da verdade, da falsidade e da diferença entre elas. A afirmação é chamada verdadeira à medida que ela se conforma ao estado das coisas e, assim, é o $\mu 01 \omega \sigma ı \zeta$. Esta determinação da essência da verdade não mais contém uma apelação a $\alpha \lambda \eta \theta \varepsilon ı \alpha$ no sentido de desocultação; pelo contrário, $\alpha \lambda \eta \theta \varepsilon \imath \alpha$, agora tomada como o oposto de $\psi \varepsilon v \delta o \varphi$ (i.e., do falso no sentido de incorreto), é pensada como correção. De agora em diante, esta caracterização da essência da verdade como correção de ambas, representação e afirmação, se torna reguladora para a totalidade do pensamento ocidental. Como evidência disto, é o suficiente citar as teses condutoras que tipificam como a essência da verdade é caracterizada nas épocas principais da metafísica. [233]

A tese de Thomas de Aquino emprega o bem para a escolástica medieval: veritasproprieinvenitur in intellectu humano vel divino (Quastiones de veritate, quaestio I, articulus4, responsio): “A verdade é encontrada propriamente no intelecto, seja humano ou divino". O intelecto está aonde a verdade tem seu lugar essencial. Neste texto, a verdade não é mais a)lh/qeia, mas o(moi/wsij (adaequatio).

No começo dos tempos modernos, Descartes estimulou a tese prévia afirmando: veritatemproprievelfalsitatem non nisi in solo intellectu esse posse (Regula ad 
directionemingenii, Regula VIII, Opusculaposthuma X, 396). "A verdade ou a falsidade, em sentido próprio, não pode estar em nenhuma outra parte senão apenas no intelecto”.

E, na época em que a era moderna chega a sua realização, Nietzsche aguça ainda mais a tese anterior quando ele diz: "A verdade é o tipo de erro sem o qual um determinado tipo de seres vivos não pode viver. Em última análise, o valor para a vida é o que é decisivo". (Nota do ano 1885, A vontade de Poder, número 493). Se a verdade é, para Nietzsche, um tipo de erro, então sua essência consiste em um modo de pensar que sempre, embora necessariamente, falsifica o real, especificamente à medida que todo ato de representar paralisa o contínuo "tornar-se" e, erigindo seus fatos estabelecidos contra o fluxo do "tornar-se", estabelece como, supostamente, o algo real que não corresponde isto é, algo incorreto e, deste modo, errôneo.

A determinação da verdade de Nietzsche como a incorreção do pensar está de acordo com a essência da verdade tradicional como a correção da afirmação $(\lambda \circ \gamma \circ \zeta)$. O conceito da verdade de Nietzsche exibe o último vislumbre da mais extrema consequência da mudança da verdade, da desocultação dos entes a correção do olhar atento. A mudança mesma foi realizada na determinação do ser dos entes (em grego: o ser presente do que é presente) como $1 \delta \varepsilon \alpha$.

Como uma consequência desta interpretação dos entes, estar presente não é mais o que era no começo do pensamento ocidental: [234] a emergência do oculto em desocultação, onde a mesma desocultação, como esclarecedora, constitui o traço fundamental do estar presente. Platão concebe o estar presente (ovol $\alpha)$ como $1 \delta \varepsilon \alpha$. Entretanto, a $1 \delta \varepsilon \alpha$ não está subordinada à desocultação, no sentido de servir ao que está desoculto, ao trazê-la à aparição. Mais propriamente, o oposto é o caso: é o resplandecer (o se mostrar) que, dentro de sua essência e em um singular relacionar a si mesmo, pode logo ser chamado desocultação. A $1 \delta \varepsilon \alpha$ não é algum primeiro plano que a $\alpha \lambda \eta \theta \varepsilon \imath \alpha$ exibe frente as coisas presentes ${ }^{167}$; antes, a $1 \delta \varepsilon \alpha$ é o fundamento que faz a $\alpha \lambda \eta \theta \varepsilon \imath \alpha$ possível. Mas, mesmo como tal, a $\imath \delta \varepsilon \alpha$ ainda reivindica algo da original, mas não reconhecida, essência da $\alpha \lambda \eta \theta \varepsilon l \alpha$.

167 Mais literalmente: “... não é o primeiro plano presente da á $\lambda \hat{n} \theta \varepsilon ı$ “ “ ["Die iOde/a istnichteindarstellenderVordergrund der $\square \square \square \square \square \square \square$...”. [Nota do tradutor]. 
A verdade, como desocultação, não é mais o traço fundamental do ser mesmo. Em vez disso, como uma consequência do estar sob o jugo da ideia, a verdade se torna correção, e, doravante, será a característica do conhecimento dos entes.

Desde então, tem existido um esforço pela "verdade", no sentido de correção do olhar e da correção de sua direção. Desde então, o que interessa, em todas as nossas orientações fundamentais em direção ao ente, é a obtenção de uma correta visão das idéias. A reflexão sobre a $\pi \alpha \iota \delta \varepsilon \imath \alpha$ e a mudança na essência da $\alpha \lambda \eta \theta \varepsilon \imath \alpha$ se pertencem e pertencem a mesma narrativa da passagem de uma morada para outra, a narrativa que é contada na "alegoria da caverna".

A diferença entre as duas moradas, uma dentro e outra fora da caverna, é uma diferença de $\sigma o \varphi ı \alpha$. Em geral esta palavra significa ser perspicaz em algo, ser hábil em algo. Falando propriamente, $\sigma 0 \varphi \iota \alpha$ significa ser perspicaz sobre aquilo que é presente como desoculto e que, como presente, perdura $^{168}$. Perspicácia não é equivalente a meramente possuir o conhecimento. Ela significa pertencer a uma morada que, em todo lugar e fundamentalmente, tem um apoio no que perdura. [235]

O tipo de perspicácia que é reguladora ali abaixo na caverna -

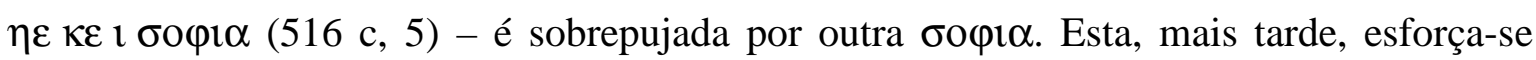
unicamente, e sobre tudo, a perceber por um instante o ser dos entes nas "ideias". Esta $\sigma o \varphi \imath \alpha$, em contraste com aquela na caverna, é distinta pelo desejo de alcançar mais além do que é imediatamente presente e adquirir um fundamento naquilo que, ao se mostrar,

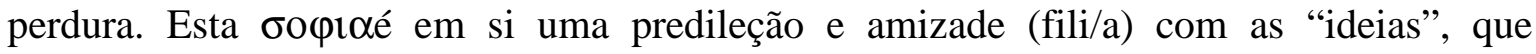
conferem o desoculto. Fora da caverna $\sigma o \varphi ı \alpha e ́ ~ \varphi ı \lambda o \sigma o \varphi ı \alpha$. A língua grega já conhecia esta palavra antes da época de Platão e usou-a em geral para nomear a predileção pela perspicácia correta. Platão apropriou primeiro a palavra como um nome para uma perspicácia específica sobre os entes que, ao mesmo tempo, define o ser dos entes como ideia. Desde Platão pensar sobre o ser dos entes se tornou "filosofia", porque ela é uma questão de olhar acima para as "ideias". Mas a "filosofia" que começa com Platão tem, deste momento em diante, a característica distintiva do que mais tarde será denominada "metafísica". Platão mesmo, concretamente, ilustra o contorno básico da metafísica na estória contada na "alegoria da caverna". De fato, a cunhagem da palavra "metafísica" já

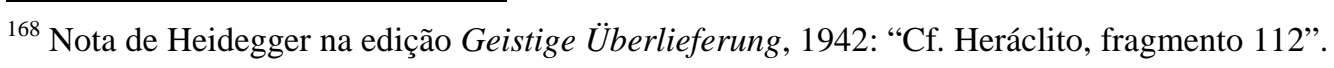


está prefigurada na apresentação de Platão. Na passagem (516) que descreve a adaptação do olhar para as ideias, Platão diz (516 c, 3): O pensar vai $\mu \varepsilon \tau \varepsilon \kappa \varepsilon \imath v \alpha$, "mais além" daquelas coisas que são experimentadas meramente na forma de simples sombras e imagens, e vai $\varepsilon 1 \zeta \tau \alpha \nu \tau \alpha$, "em direção para fora" dessas coisas, a saber, as "ideias". Estas são o suprasensível, visto com um olhar não sensível; elas são o ser dos entes, que não podem ser apreendidas com nossos órgãos corpóreos. E o mais elevado no território do suprasensível é aquela ideia que, como ideia de todas as ideias, permanece a causa da existência e aparição de todos os entes. Porque esta "ideia" é, desse modo, a causa de tudo, logo, ela é também "a ideia” que é chamada "o bem”. Esta mais elevada e primeira causa é chamada por Platão, e correspondentemente por Aristóteles, $\tau$ o $\theta \varepsilon \iota$ ovo, o divino. Desde então, o ser foi interpretado como $1 \delta \varepsilon \alpha$, o pensar sobre o ser dos entes [236] tornou-se metafísico, e a metafísica tornou-se teológica. Neste caso, teologia significa a interpretação da "causa" dos entes como Deus e a transferência do ser a essa causa, que contém o ser em si e dispensa o ser para fora de si, porque ela é o mais entitativo ${ }^{169}$ dos entes.

Esta mesma interpretação do ser como $1 \delta \varepsilon \alpha$, que deve sua primazia a uma mudança na essência da $\alpha \lambda \eta \theta \varepsilon ı \alpha$, requer que ao ver as ideias seja conferida alta distinção. Correspondendo a esta distinção está a $\pi \alpha \iota \delta \varepsilon ı \alpha$, a “instrução" dos seres humanos. Ocupando-se com os seres humanos e com a posição dos humanos entre os entes, esta domina totalmente a metafísica.

O começo da metafísica no pensamento de Platão é, ao mesmo tempo, o começo do "humanismo". Aqui a palavra tem que ser pensada em sua essência e, portanto, em seu sentido mais amplo. Nesta consideração, "humanismo" significa o processo que é envolvido no começo, no desdobrar-se e no fim da metafísica, por meio do qual os seres humanos, em variados aspectos, mas sempre deliberadamente, se movem para um lugar central entre os entes, obviamente, desse modo, sem ser o ente mais elevado. Aqui "ser humano" algumas vezes significa humanidade ou gênero humano, algumas vezes o indivíduo ou a comunidade e algumas vezes o povo [das Volk] ou o grupo de pessoas. O que está sempre em jogo é isto: tomar os "seres humanos", que dentro da esfera de um sistema fundamental metafisicamente estabelecido de entes, são definidos como animal rationale, e os conduzir, dentro desta esfera, para a liberação de suas possibilidades, para a certeza dos seus destinos e para a proteção de suas vidas. Isto

${ }^{169}$ Em inglês: "being-est"; em alemão "Seindste". 
acontece como conformação de seus comportamentos "morais", como a salvação de suas almas imortais, como o desdobramento dos seus poderes criativos, como o desenvolvimento das suas razões, como a nutrição de suas personalidades, como o despertar de seus sentidos cívicos, como o desenvolvimento de seus corpos, ou como uma combinação apropriada de alguns ou de todos estes "humanismos". O que ocorre em cada instância é uma rotação metafisicamente determinada ao redor do ser humano, quer em órbita estreita quer em ampla. Com a realização da metafísica, o "humanismo" (ou [237] em termos "gregos": a antropologia) também avança para as mais extremas - e igualmente incondicionadas - "posições".

O pensamento de Platão segue a mudança na essência da verdade, mudança que se torna história da metafísica, a qual no pensamento de Nietzsche entra em realização incondicionada. Desta forma, a doutrina de Platão sobre a verdade não é algo que é passado. Ela é historicamente "presente", não apenas no sentido de que suas doutrinas têm um "efeito posterior" que os historiadores podem calcular, nem como um ressurgir ou uma imitação da antiguidade, nem mesmo como a mera preservação do que foi legado. Mais propriamente, esta mudança na essência da verdade está presente como a toda poderosa realidade fundamental - estabelecida por longo tempo e, consequientemente, ainda adequada - da, sempre em avanço, história mundial do planeta neste mais moderno dos tempos modernos.

Tudo o que acontece com os seres humanos históricos advém, em cada caso, de uma decisão sobre a essência da verdade que aconteceu há muito tempo e nunca de acordo com os humanos exclusivamente. Através desta decisão, as linhas estão sempre já desenhadas considerando o que, na luz da essência da verdade instituída, é procurado e estabelecido como verdade e, igualmente, o que é desprezado e ignorado como não verdadeiro.

A estória contada na "alegoria da caverna" oferece um olhar rápido do que está realmente acontecendo na história da humanidade ocidental, igualmente agora e no futuro: Tomando a essência da verdade como a correção da representação, pensa-se todos os entes de acordo com as "ideias" e avalia-se toda realidade de acordo com os "valores". Aquilo que sozinho, e em primeiro lugar, é decisivo não é quais ideias e quais valores são postos, mas antes, o fato de que o real é interpretado sob qualquer condição de 
acordo com as "ideias" e que o "mundo" é pesado sob qualquer condição de acordo com os "valores".

Entretanto, nós temos lembrado a essência da verdade original. A desocultação ${ }^{170}$ se revela para esta lembrança como o traço fundamental dos entes $\operatorname{mesmos}^{171}$. Apesar disso, a lembrança da [238] essência original da verdade tem que pensar esta essência mais originalmente. Portanto, tal lembrança nunca poderá tomar a desocultação meramente no sentido de Platão, isto é, como sob o jugo da $1 \delta \varepsilon \alpha$. Como Platão a concebe, a desocultação permanece subordinada a uma relação com o olhar, o apreender, o pensar e o afirmar. Obedecer esta relação significa abandonar a essência da desocultação. Nenhuma tentativa de fundamentar a essência da desocultação na "razão", no "espírito", no "pensar", no "logos" ou em qualquer tipo de "subjetividade", pode alguma vez salvar a essência da desocultação. Em todas essas tentativas, o que tem que ser fundamentado - a essência da desocultação mesma - ainda não é adequadamente procurado. O que sempre fica "aclarado" é somente alguma consequência essencial da essência não compreendida da desocultação.

Primeiramente é requerido uma apreciação do "positivo" na essência "privativa" da $\alpha \lambda \eta \theta \varepsilon \iota \alpha$. O positivo tem que ser primeiro experimentado como o traço fundamental do ser mesmo. Antes de mais nada, o que tem que irromper sobre nós é a exigência por meio da qual nós somos compelidos a questionar não apenas os entes no seu ser, mas o ser mesmo ( que é a diferença). Porque esta exigência encontra-se diante de nós, a essência original da verdade repousa em sua origem oculta.

\section{FIM}

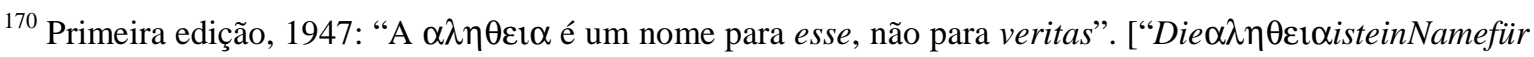
esse, nichtfürveritas"].

${ }^{171}$ Primeira edição, 1947: "que é, como ser" [d.h. als das Seyn].
} 


\section{RAZÕES FINAIS}

O trabalho é curto e incompleto porque, infelizmente, há um prazo a ser cumprido.

O estudo do sujeito de direito na visão heideggeriana ainda é uma floresta que permite não só tantas outras trilhas, como um aprofundar nesta que, conscientemente, foi apenas uma pequena abertura de início de caminhada.

Verifica-se que o sujeito de direito e a subjetividade jurídica é instituto de fabricação histórica que, apesar de possuir raízes no cristianismo primitivo, foi forjado e amadurecido pela modernidade.

O Iluminismo projetou e sustentou a noção de sujeito de direito e de subjetivismo com o claro intuito de promover e amparar a mentalidade capitalista que caráter técnico-instrumental. A igualdade e a liberdade tão proclamadas são, na verdade, dois escuros do mercado e da livre mercantilização de bens, serviços e, infelizmente, até mesmo pessoas.

Mas a consciência de que a existência autêntica é inevitavelmente sercom traz uma possibilidade de que o homem, o Dasein, poderá escolher viver sendo sercom-o-outro. Não há coisas, nem pessoas.

Há a existência de entes e o sentido do ser, essencialmente sociais, para serem eleitos como objetos de investigação, mesmo que sem a certeza do encontro, porque a incerteza do conhecimento não retira o encanto da busca. No campo jurídico, o das necessidades que atualmente são mais que urgentes e emergentes.

Tudo porque a existência social pede que o Dasein faça o que somente ele pode fazer: pense.

O sujeito de direito é um constructo, uma figura do intelecto, que permite a submissão do Dasein ao sistema, ao encerrar suas possibilidades no domínio dos seus limites.

José Gaos diz: 
“El 'ser ahí' se depara a si mismo la possibilidad de perderse em el ' uno’: el 'ser em el mundo' es de suyo uma constante 'tentación' a la ‘caída'.

Lo seguro de sí que es el 'uno' esparce uma creciente convicción de que no es menester compreender-encontrándose 'propiamente', de que todo sucede en el mejor de los mundos, de que todos tienen abiertas todas las puertas: el 'tentador' 'ser en el mundo' da al 'ser ahí' um decidido 'aquietamiento'.

Mas el 'tentador' 'aquietamiento' no hace sino dar vuelos a la 'caída'. En vez de apartar hacia la quietude, arrasta hasta el más desenfrenado 'tráfago'. En particular, engendra la opinión de que la comprensión de las culturas más extrañas a la peculiar y su sínteses com ésta ilustra real y verdadeiramente al 'ser ahí' acerca de sí, aunque la verdade es que ni se precisa qué es lo que habría realmente que compreender, ni siquiera se hace de ello custión". ${ }^{172}$

Mas isto não é existir, não é ter existência, pois esta implica liberdade de possibilidades.

Só na liberdade o Dasein está aberto ao mundo. Somos mundo na possibilidade, na liberdade e no encontro da verdade.

Há ainda outros temas e questões importantes que não foram debatidos e explorados suficientemente no pensamento de Heidegger, como aponta Jeannette Antonios Maman em suas aulas na pós-graduação e nas suas conversas com seus orientandos, a saber:

1. O radical é o lugar do enraizamento, é a morada do ser. É o des-fundo, é o fundo sem fundo, o abismo. Quando se tira o último fundamento, resta o Abgrund.

2. Ser e tempo não percebidos na raiz pela liberdade - é deixar ser. Não é um atributo da pessoa; é um poder ser - é possibilidade de ser. A liberdade é o fenômeno do deixar ser o ente. A liberdade está aquém do ser e tempo e lhe vem anteriormente.

3. Nietzsche mostra a necessidade de agressividade e de desconstrução, noções que passam para pós-modernos.

${ }^{172}$ Introducción a el ser y el tempo de martin heidegger, p. 54. 
4. A liberdade e o pensamento não no plano da psicologia. O certo é considerar que a pessoa pertence ao ser, o logos, a palavra pensante é do ser. O homem é chamado ao ser para contribuir com a verdade do ser. Alcançar o pensar na experiência recusa uma realização do ser humano no plano do conceito, o esforço é no sentimento de libertar o pensar humano do conceito (da ideia). 


\section{CONCLUSÃO}

Desejar entender Heidegger é o mesmo que desejar retornar a busca do sentido do ser. É querer mergulhar no Dasein e, assim, descobrir o que o ente oculta e revela. É se encontrar no meio da floresta, sem que isto fosse o planejado e, nela, encontrar uma clareira (Lichtung)que sirva de referência, descanso e abrigo.

Para tanto, se deve perceber que hoje temos uma matematização do mundo direito, seja nas decisões, seja nas argumentações, chegando ao ponto de privar os juízes do seu livre convencimento. O Poder Judiciário não pode ser transformado numa grande indústria, numa fábrica moderna de produção de decisões, sem que isto tenha por resultado a perda da sua autenticidade. A decisão é como a obra de arte do jurista (o juiz, no caso). O direito é dos artistas, onde o humano é o fundamental.

Não se pretende opor direito e ciência. Contudo, a ciência faz, não pensa... O pensar é próprio do Dasein que faz filosofia. O que se busca é uma via que talvez provoque o retorno ao direito autêntico, dentro de uma discussão ética. Afinal, um novo direito.

Depois do trabalho, fica conhecido que não há sujeito no pensamento grego. É no pensamento moderno que o sujeito de direito e seu subjetivismo surgem, criados pelo modernismo para limitar a liberdade e a verdade enquanto realização da possibilidade. Quando o Daseinse pergunta o que lhe é essencial, acontece a resposta: realização de uma possibilidade. Nada é mais livre, nada lhe é mais própria.

A problemática heideggeriana do ser próprio se liga diretamente à noção de características, o que nos leva a ver a existência à luz da questão "quê". Essa questão responde ao ser si mesmo no sujeito de si, resoluto quanto às suas possibilidades.

Selbst é traduzido por "si mesmo", o que estabelece um paralelo com a hermenêutica de Paul Ricoeur onde "si mesmo" como "um outro" é a relação que se põe.

Ser si mesmo é ser si próprio em suas possibilidades que facilitam a realização de suas características. 
Não se abandona aqui a analítica existencial do Dasein, isto porque toda a constituição existencial traz em si a noção de ser no mundo com o outro. Então isto do que se fala e do que se trata e o que se relata não é o sujeito moral da imputação, o que distancia a fenomenologia em princípio da questão impositiva do direito.

Em Heidegger, a noção da analítica existencial é aquela de souci (preocupação, cura); pode-se pensar que o cuidado ontológico também tem implicação no agir. Mas este agir é um recolher, um acolher e cuidar, trata-se de agir identificando um outro, um outro ente como si mesmo. Esta igualdade subjacente a alterações múltiplas faz com que pensemos na mudança quase que ao modo de Parmênides, que no compartilhar da escola eleata, afirma que "tudo (o que é) é, ou seja, o que existe é o ser, ou melhor, o ser é o que existe! Designava igual noção de devir como "tornar-se" ou "vira ser", designava a dinâmica do ser, um devir qualitativo, onde "o que é único, não se muda"173, ou, ao menos, a razão não lhe alcança.

O sujeito é uma substância que se mantém idêntica mesmo que passe por mudanças. Como se encontra em Ser e Tempo:

“A substancialidade é o guia ontológico da determinação dos entes a partir do qual se responde à pergunta quem.". ${ }^{174}$

Artur Rimbaud na filosofia de sua poética dizia que o "eu" da cotidianidade é "um outro". Trata-se aqui da alienação, se em nossas ocupações ou em nossa condição habitual não temos a posse de si, mas, ao contrário, a perda de si na rotina alienante e sem sentido das ocupações repetidas - "dos nossos negócios".

Abre-se a questão da analítica existencial em seu aspecto cotidiano e transcendental.

Posta a questão "quem" nós temos que compreender a ipseidade do Dasein, mas não se trata de um agir com um retorno reflexivo sobre si mesmo, nem um retorno a imanência radical da subjetividade.

O outro próprio é um mesmo porque como todos nós temos a condição no mundo - o outro é um co-existente, o que corresponde à expressão alemã Mil-Dasein.

\footnotetext{
${ }^{173}$ Alysson L. Mascaro, Filosofia do direito, p. 35.

${ }^{174}$ Vozes, p. 165.
} 
Podemos pensar então que o "sujeito" se dissolve no anonimato das "estruturas" de algum modo, porque o sujeito é determinação essencial do Dasein (determinação como condição existencial).

Não há jamais sujeito sem mundo e isolado, aquilo que é próprio pede uma interpretação existencial.

Novamente Heidegger em Ser e Tempo:

"El 'con' es algo que tiene la forma de ser del 'ser ahi', el 'también' mienta la igualdade del ser, en el sentido del 'ser em el mundo' 'curándose de' y 'viendo em torno'. Hay que compreender el 'con' y el 'también' existenciaria y no categorialmente. En razón de este concomitante 'ser en el mundo' es el mundo en cada caso ya siempre aquel que comparto com los otros. El mundo del 'ser ahí' es un 'mundo del con'. El 'ser en' es 'ser con' otros. El 'ser en si’intramundado de éstos es "ser ahí con"”. 175

Esta tal hermenêutica não se atém à "substância" do homem e nem nela se fundamenta, pois a substância não é se não a existência. A essência é a existência.

A constituição existencial ao lado do cotidiano tem também o seu modo de ser, o autêntico como essencialidade do Dasein. É no modo autêntico de ser que o Dasein realiza suas possibilidades mais próprias - sê o que tu és. Este modo de ser implica a mundanidade.

A consciência do Dasein é sempre fora de si mesmo, é a consciência de ser lançado, de ser projetado. Esta é a influência de Husserl em Heidegger e na transcendência tudo desaparece da existência cotidiana que permanece como suspensa; não há mais instantes calculados de poder ou de um abismo artificial de identificação, um abismo de subjetividade.

Não há subjetividade em Heidegger porque desde o início somos "sercom". Nenhum sujeito é dado sem o mundo: ele é sempre com-o-outro-no-mundo.

As consequências para o direito são possibilidades para novos estudos!

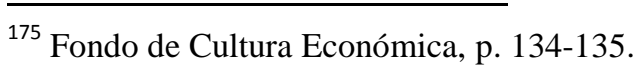




\section{BIBLIOGRAFIA}

ABBAGNANO, Nicola . Dicionário de Filosofia-revista e ampliada . São Paulo, Martins Fontes, 2007.

História da Filosofia . volume XII, São Paulo, Presença, 2001. História da Filosofia . volume XIV, São Paulo, Presença, 2001.

ARCELO, Adalberto Antonio Batista . Dogmática Jurídica e Complexidade: o paradoxo dos direitos humanos como condição de possibilidade para a justificação racional do discurso jurídico . in Revista da Faculdade de Direito Milton Campos, volume XI, Belo Horizonte, Del Rey, 2004.

BACCA, Mays Garcia . Ensayos sobre la Tecnica em Ortega, Heidegger . Espanha, Anthropos, 2002.

BADIOU, Alain . L’Être et l'Événement . Paris, Seuil, 1988.

BEAINI, Thais Curi . Escuta do Silêncio - um estudo sobre a linguagem no pensamento de Heidegger . São Paulo, Cortez, 1981.

BEAUFRET, Jean . Introdução às Filosofias da Existência . São Paulo, Duas Cidades, 1976.

BICUDO, Juliana Morais . A investigação Fenomenológica da Liberdade em Martin Heidegger . tese de mestrado, Faculdade de Direito da Universidade de São Paulo, 2008.

CRÉPON, Marc . Les Promesses Du Language - Benjamin, Rosenzweig, Heidegger . Paris, J. Vrin, 2001.

CRITELLI, Dulce Mara . Martin Heidegger e a Essência da Técnica . in Revista Margem da Pontifícia Universidade Católica de São Paulo, 16, dez/2002.

DABÍN, Jean . El DerechoSubjetivo . Madrid, Editorial Revista de Derecho Privado, 1955.

DESCARTES, René . Discurso do Método . Porto Alegre, L\&PM, 2009.

ECO, Umberto . Como se faz uma Tese . São Paulo, Perspectiva, 1991 
FIGAL, Günter . Martin Heidegger: Fenomenologia da Liberdade . Rio de Janeiro, Forense Universitária, 2005.

FOUCAULT, Michel . A Hermenêutica do Sujeito . São Paulo, Martins Fontes, 2011.

FRANÇA, R. Limongi (cood) . Enciclopédia Saraiva do Direito . São Paulo, Saraiva, 1982.

FURLAN, Valéria (org). Sujeito no Direito. Curitiba, CRV, 2012.

GALLI, Graziela . Direito ao Desenvolvimento: contribuição de fenomenologia jurídica .tese de mestrado, Faculdade de Direito da Universidade de São Paulo, 2009.

GARCIA-ROZA, Liz Alfredo . Palavra e Verdade na Filosofia Antiga e na psicanálise . Rio de Janeiro, Jorge Zahar, 1990.

GADAMER, Hans-Georg . Heidegger em Retrospectiva . Petrópolis, Vozes, 2007.

GMEINER, Conceição Neves . A Morada do Ser - uma abordagem filosófica da linguagem de Martin Heidegger. São Paulo, Loyola, 1998.

HABERMAS, Jürgen . Direito e Democracia - entre a facticidade e validade .volume I, Rio de Janeiro, Tempo Brasileiro, 1997.

HEGEL, Georg Wilhelm Friedrich . Fenomenologia do Espírito . Petrópolis, Vozes, 1992. . Filosofía del Derecho . México, Dirección General de Publicaciones, 1975.

. Princípios da Filosofia do Direito . São Paulo,

Martins Fontes, 1997.

HEIDEGGER, Martin . A Caminho da Linguagem . Petrópolis, Vozes, 2008. . Acheminement vers la Parole . Paris, Gallimard, 1959. . Carta sobre o Humanismo . Lisboa, Guimarães, 1987. . Cheminsquine Mènent nulle Part . Paris, Gallimard, 1980. . El Ser y elTiempo .México, Fondo de Cultura Económica, 1999. 
. Ensaios e Conferências . Petrópolis, Vozes, 2008.

. Escritos Políticos . Lisboa, Instituto Piaget, 1994.

. EssaisetConférences . Paris, Gallimar, 1958,

. Fenomenologia da Vida Religiosa . Petrópolis, Vozes, 2010.

. Heráclito . Rio de Janeiro, Relume Dumará, 1998.

. História da Filosofia - de Tomás de Aquino a Kant . Petrópolis,

Vozes, 2006.

. Introdução à Filosofia . São Paulo, Martins Fontes, 2005.

. Introdução à Metafísica . Rio de Janeiro, Tempo Brasileiro, 1999.

. Introduction à laMétaphysique . Paris, Gallimard, 1952.

. Le Principe de Raison . Paris, Gallimard, 1962.

. Língua de Tradição e Língua Técnica . Lisboa, Veja Passagens,

1995.

. Lógica - A Pergunta sobre a Essência da Linguagem . Rio de Janeiro, CaulosteGulbenkian, 2008.

. Marcas do Caminho . Petrópolis, Vozes, 2008.

. Meditação .Petrópolis, Vozes, 2010.

. Philosophical and Political Writings. Nova York, Manfred Stassen,

2003.

. Poetry, Language, Thought . Nova York, 2001.

.Qu'Appelle-t-on Penser? . Paris, Quadrige, 1959.

. Qu'est-ce qu'une Chose? . Paris, Gallimard, 1962.

. Que é uma Coisa? . Rio de Janeiro, Edições 70, 1987.

Que é isto - a Filosofia? . Petrópolis, Vozes, 2006. 
. Qué significa Pensar? . Madrid, Trotta, 1997.

. Questions I etII . Paris, Gallimard, 1968.

. Questions III et IV . Paris, Gallimard, 1976.

. Reponses et Questions sur l'Histoire et La Politique . França,

Mercure de France, 1977.

. Reponses et Questions surl'Histoire et La Politique. França,

Mercure de France, 1988.

. Ser e Tempo . Petrópolis, Vozes, 1999.

. Ser e Verdade . Petrópolis, Vozes, 2007.

. Sobre a Essência da Verdade . Portugal, Porto, 1995.

. Sobre a Questão do Pensamento . Petrópolis, Vozes, 2009.

. The End of Philosophy . Chicago, University of Chicago, 2003.

. Todos nós... Ninguém - um enfoque fenomenológico do social . São

Paulo, Moraes, 1981.

HOTTOIS, Gilbert . Du Sens Commun a la Societe de Communication: etudes de phylosophie du language (Moore, Wittgenstein, Wisdom, Heidegger, Perelman, Apel) . Paris, J. Vrin, 1989.

HUSSERL, Edmund . Investigações Lógicas . in Os Pensadores, São Paulo, Nova Cultural, 1988.

KANT, Immanuel . A Paz Perpétua e Outros Opúsculos . Lisboa, Edições 70, 2008.

. Crítica da Razão Prática . São Paulo, Martins Fontes, 2011.

. Crítica da Razão Pura . Petrópolis, Vozes, 2012.

. Metafísica dos Costumes . São Paulo, Edipro, 2008.

KELSEN, Hans . Teoria Geral do Direito e do Estado . São Paulo, Martins Fontes, 2000. 
LAFONT, Cristina . Heidegger, Language and World-Disclosure . Cambridge, Cambridge University Press, 2000.

LEVY, Maria Stella Ferreira . Linguagem e suas Aplicações no Direito . São Paulo, Paulistana, 2006.

MAMAN, Jeannette Antonios . Ao Encontro de Heidegger: a noção de ser-no-mundo . in Revista da Faculdade de Direito da Universidade de São Paulo, volume 102, 2007. - A Via Investigativa da Filosofia do Ser e o Fenômeno Jurídico . in Revista da Faculdade de Direito da Universidade de São Paulo, volume 99, 2004. . Fenomenologia Existencial do Direito . São Paulo, Edipro, 2000 . Fenomenologia Existencial do Direito . São Paulo,

QuartierLatin, 2003. . Fixação de Alguns Pressupostos Ontológicos para uma Investigação Fenomenológica do Direito . trabalho de evento, in FDUSP, 1997. . Língua e Linguagem: os artifícios e a verdade jurídica in Revista da Faculdade de Direito da Universidade de São Paulo, volume 98, 2003. - O Fenômeno Jurídico como Objeto de uma Ontologia Fundamental . in Revista da Faculdade de Direito da Universidade de São Paulo, volume 94, 1999.

MANGEL, Alberto . No Bosque do Espelho . São Paulo, Cia. Letras, 2000.

MARX, Karl . A Ideologia Alemã: teses sobre Feuerbach . São Paulo, Centauro, 2006. . Crítica da Filosofia do Direito de Hegel . São Paulo,Boitempo, 2010. . Manifesto Comunista. São Paulo, Boitempo, 2007. . O 18 Brumário de Napoleão Bonaparte. São Paulo, Boitempo, 2011. . O Capital . Bauru, Edipro, 2008. 
. O Capital . São Paulo, Nova Cultural,

MASCARO, Alysson Leandro . Filosofia do Direito . São Paulo, Atlas, 2012.

. Introdução ao Estudo do Direito . São Paulo, Atlas, 2013.

MERLEAU-PONTY, Maurice . Fenomenologia da Percepção . São Paulo, Martins Fontes, 1999.

MICHEL, Albin . Dictionnaire de la Philosophie . Paris, EncyclopaediaUniversalis, 2000.

OLIVEIRA, Rubens Mendes de . A Questão da Técnica em Spengler e Heidegger, UFMG, 2000 .

PACHUKANIS, Eugeni B. . A Teoria Geral do Direito e o Marxismo . Rio de Janeiro, Renovar, 1989.

PEREIRA, Aloysio Ferraz . Estado e Direito na Perspectiva da Libertação - uma crítica segundo Martin Heidegger. São Paulo, Revista dos Tribunais, 1980.

. Textos de Filosofia Geral e de Filosofia do Direito . São

Paulo, Revista dos Tribunais, 1980.

PROSCURCIN JÚNIOR, Pedro . Investigação Fenomenológica e Sentido Originário do Ethos, tese de mestrado, Faculdade de Direito da Universidade de São Paulo, 2007.

RADBRUCH, Gustav . Filosofia do Direito . São Paulo, Martins Fontes, 2011.

REALE, Miguel . Filosofia do Direito . São Paulo, Saraiva, 2009.

ROSENFIELD, Denis . Política e Liberdade em Hegel . São Paulo, Brasiliense, 1983.

RÜDIGER, Francisco . Martin Heidegger e a Questão da Técnica: prospectos acerca do futuro do homem . Porto Alegre, Sulina, 2006.

RUDIGER, Safranski . Heidegger - um mestre da Alemanha entre o bem e o mal . São Paulo, Geração Editorial, 2000.

SILVA, Franklin Leopoldo e . Martin Heidegger e a Técnica . in Scientiae Studia, volume 5, número 3, 2007.

SILVA, Luciano Correia da . Direito e Linguagem . São Paulo, Edipro, 1999. 
SOUCHE-DAGUES, Denise . Du Logos chez Heidegger . Grenoble, Jérôme Millon, 1999.

STEIN, Ernildo . Pensar e Errar - um ajuste com Heidegger. Ijuí, Unijuí, 2011.

STEINER, George . As Idéias de Heidegger . São Paulo, Cultrix, 1978.

VILLEY, Michel . Filosofia do Direito - definições e fins do direito . São Paulo, Atlas, 1977.

. A Formação do Pensamento Jurídico Moderno . São Paulo, Martins

Fontes, 2005.

WERLE, Marco Aurélio . A Questão da Técnica .in Scientiae Studia, volume 5, número 3, 2007.

ZAKA, Yves Charles . La Invención del Sujeto de Derecho, Paris, 1999.

. La Outra Vía de la Subjetividad . Madrid, Dykinson, 2006. 